\title{
FERNANDO SILVEIRA
}

\section{A Prática de Saúde Bucal em uma Equipe de Saúde da Família}

Tese apresentada à Escola de Enfermagem de Ribeirão Preto da Universidade de São Paulo, para obtenção do título Doutor em Ciências, Programa de Enfermagem em Saúde Pública.

Linha de Pesquisa: Práticas, Saberes e Políticas de Saúde.

Orientadora: Profa. Dra. Silvana Martins Mishima

Coorientadora: Profa. Dra. Marlívia Gonçalves de Carvalho Watanabe 
Autorizo a reprodução e divulgação total ou parcial deste trabalho, por qualquer meio convencional ou eletrônico, para fins de estudo e pesquisa, desde que citada a fonte.

Silveira, Fernando

A prática de saúde bucal em uma equipe de saúde da família. Ribeirão Preto, 2011.

p. 151 : il. ; $30 \mathrm{~cm}$

Tese (Doutorado), apresentada à Escola de Enfermagem de Ribeirão Preto/USP. Área de concentração: Enfermagem de Saúde Pública.

Orientador: Mishima, Silvana Martins

Coorientadora: Watanabe, Marlívia Gonçalves de Carvalho

1. Atenção à Saúde, 2. Odontologia em Saúde Coletiva, 3. Interdisciplinaridade, 4. Saúde da Família, 5. Cuidados Integrais de Saúde. 
SILVEIRA, Fernando.

A PRÁTICA DE SAÚDE BUCAL EM UMA EQUIPE DE SAÚDE DA FAMÍLIA

Tese apresentada à Escola de Enfermagem de Ribeirão Preto da Universidade de São Paulo, para obtenção do título de Doutor em Ciências, Programa de Enfermagem em Saúde Pública.

Aprovado em:

\section{BANCA EXAMINADORA}

Prof. Dr.

Instituição:

Assinatura:

Prof. Dr.

Instituição:

Assinatura:

Prof. Dr.

Instituição:

Assinatura:

Prof. Dr.

Instituição:

Assinatura:

Prof. Dr.

Instituição:

Assinatura: 
Dedico este estudo à

Profa. Dra. Maria Cecília Puntel de Almeida, pela forma carinhosa e responsável que iniciamos este estudo

(in memoriam).

\section{A UM AUSENTE}

Tenho razão de sentir saudade, tenho razão de te acusar.

Houve um pacto implícito que rompeste e sem te despedires foste embora.

Detonaste o pacto.

Detonaste a vida geral, a comum aquiescência de viver e explorar os rumos de obscuridade sem prazo sem consulta sem provocação até o limite das folhas caídas na hora de cair.

Antecipaste a hora. Teu ponteiro enlouqueceu, enlouquecendo nossas horas.

Que poderias ter feito de mais grave do que o ato sem continuação, o ato em si, $o$ ato que não ousamos nem sabemos ousar porque depois dele não há nada?

Tenho razão para sentir saudade de ti, de nossa convivência em falas camaradas, simples apertar de mãos, nem isso, voz modulando sílabas conhecidas e banais que eram sempre certeza e segurança.

Sim, tenho saudades. Sim, acuso-te porque fizeste o não previsto nas leis da amizade e da natureza nem nos deixaste sequer o direito de indagar porque o fizeste, porque te foste.

Carlos Drummond de Andrade 


\section{AGRADECIMENTOS}

À nós, pesquisadores e Unidade de Saúde da Família Rubi, que nos envolvemos com a produção deste trabalho, acreditando que é possível produzir cuidados de saúde e projetos para a vida.

À aqueles que mais compartilharam os meus sentimentos de alegria, tristeza, frustrações, vitória e esperança nesta jornada, Soraya, Mariana, Marília e Arthur Henrique e que souberam compreender a ausência em função de uma utopia ativa.

Às Profa. Dra. Silvana Martins Mishima, pela disponibilidade em assumir este projeto, mas principalmente pela alteridade, pela produção conjunta, pela capacidade de permitir o aprimoramento intelectual no tempo de cada orientando, e de forma auto-reflexiva, o que tornaram as reuniões de orientação produtivas e agradáveis.

À Profa. Dra. Marlívia Gonçalves Carvalho Watanabe, que compartilhou o desafio de apreender o Movimento Institucionalista e a Cartografia, as inquietações a respeito da Saúde Bucal na equipe de Saúde da Família e incentivadora deste estudo.

Aos meus pais, Maria Ignez e Walter (in memoriam), pelas sementes plantadas no início das nossas vidas e que vão desabrochando no correr dos anos.

Ao grupo de discussão sobre Análise Institucional e Esquizoanálise de Ribeirão Preto, em especial aos docentes da Escola de Enfermagem de Ribeirão Preto, Silvia Matumoto, Cinira Magali Fortuna, Maria José Bistaffa e discentes Lucas Vinco de Oliveira Campos e Nunila Ferreira de Oliveira, pelas discussões a respeito do referencial metodológico e dos dados produzidos.

Ao Dr. Jorge Bichuetti pela colaboração na discussão a respeito do trabalho em equipe.

Aos alunos e docentes do Curso de Especialização em Análise Institucional, Esquizoanálise e Esquizodrama, clínica de indivíduos, grupos, organizações e redes sociais, pela contribuição teórica e prática no sentido de facilitar a compreensão da Esquizoanálise e Movimento Institucional.

Aos professores da área de Saúde Coletiva da Faculdade de Odontologia de Ribeirão Preto, Ricardo Henrique Alves da Silva, Soraya Fernandes Mestriner, Wilson Mestriner Júnior, Janete Cinira Bragagnolo, pela colaboração no desenvolvimento deste estudo nas Unidades de Saúde da Família.

À comunidade da Faculdade de Odontologia de Ribeirão Preto, em especial a professora Mariane Gonçalves, pela colaboração e estímulo para conclusão deste trabalho.

Ao Dorival Gaspar, nosso companheiro da área de Saúde Coletiva, pela sua dedicação a área e ponderações atentas.

Aos funcionários da Escola de Enfermagem de Ribeirão Preto - USP, pelas colaborações na produção deste estudo, em especial à Shirley Ferreira de Figueiredo, Cristiane Gramani Say e a bibliotecária da Biblioteca Centra do Campus Ribierão Preto - USP, Maria Cristina Manduca Ferreira.. 


\section{RESUMO}

SILVEIRA, F. A prática da Saúde Bucal nas equipes de Saúde da Família. 2011. Tese (Doutorado) - Escola de Enfermagem de Ribeirão Preto, Universidade de São Paulo, Ribeirão Preto, 2011.

Esta pesquisa tem por objetivo investigar as possibilidades e os limites para a construção de práticas de Saúde Bucal na produção de cuidado à Saúde por uma Equipe de Saúde da Família. A interação de saberes e a articulação de ações entre atores de distintas disciplinas da saúde podem levar a uma relação interdisciplinar e conformar um campo de competências e responsabilidades voltado para ações de Saúde Bucal Coletiva. O Ministério da Saúde tem enfatizado, junto às equipes de saúde a adoção de práticas interdisciplinares por meio das políticas de Atenção Básica à Saúde, Estratégia Saúde da Família e das Diretrizes Nacionais de Saúde Bucal. Trata-se de um estudo cartográfico do cotidiano da equipe baseado na perspectiva da Pesquisa-Intervenção e fundamentado no Movimento Institucionalista. Trabalhou-se com dados primários produzidos nas reuniões de equipe administrativas e de discussão de casos de família que foram gravadas em áudio e posteriormente transcritas. Também fizeram parte dos dados o diário de campo das atividades de observação participante e das reuniões do grupo de pesquisa e de estudo. No percurso da pesquisa, foram produzidos analisadores que tiveram o objetivo de mobilizar a equipe para produzir um conhecimento a respeito de seu processo de trabalho e da Saúde Bucal, tais como a organização da agenda da Saúde Bucal; a equipe e uma de suas famílias: o caso da família do Sabiá Laranjeira e a discussão sobre a inserção da Saúde Bucal na Equipe de Saúde da Família Rubi. Foram identificados eixos transversais ao conhecimento produzido. Um deles refere-se às relações entre os trabalhadores da equipe, que a consideraram como justaposição de saberes, construída a partir das relações interpessoais. O outro expressa uma das tensões que a equipe vivencia com assistência, atenção à saúde e clínica ampliada. Essas tensões estão baseadas nos desencontros da oferta e da demanda dos serviços na unidade e na valorização exclusiva do aparato tecnológico da saúde. O terceiro eixo trata da alienação presente no processo de trabalho, determinada pela percepção fragmentada dos trabalhadores e usuários a respeito do objeto da produção do cuidado à saúde. $\mathrm{O}$ último eixo expõe tensões na arena da Atenção Básica em Saúde e da Estratégia Saúde da Família em função da formação do profissional de saúde para o trabalho em equipe. O método Cartográfico possibilitou acompanhar a processualidade da equipe e expor tensões presentes no seu processo de trabalho. Foi verificado que a construção de um campo de saberes e práticas voltadas para ações de Saúde Bucal Coletiva se constitui em processo influenciado pelas tensões do cotidiano do trabalho em equipe, e que determina a sua configuração ou não. Entretanto, nos momentos em que a interação e articulação foram construídas, mostrou-se potente para compor práticas de saúde mais qualificadas.

Palavras-chave: Atenção à Saúde; Odontologia em Saúde Coletiva; Interdisciplinaridade; Programa Saúde da Família; Cuidados Integrais de Saúde. 


\begin{abstract}
SILVEIRA, F. The Oral Health practice in the Family Health Teams. 2011. Tese (Doutorado) - Escola de Enfermagem de Ribeirão Preto, Universidade de São Paulo, Ribeirão Preto, 2011.

This research aims to investigate the possibilities and limits for the construction of Oral Health practices in the production of health care by a Family Health Team. The interaction of knowledge and the coordination of actions among actors from different health fields can lead to an interdisciplinary relationship and to suit a field of competence and responsibility aimed for actions of Collective Oral Health. The Ministry of Health has emphasized with health teams the adoption of interdisciplinary practices through policies of Primary Care, Family Health Strategy and the National Guidelines on Oral Health. It is a cartographic study of everyday team based on the perspective of Research-Intervention and grounded on the Institutional Movement. Primary data was produced in administrative team meetings and in discussion of family affairs, which were audio taped and later transcribed. The daily field activities of participant observation and of meetings of the group and study were also part of the data. In the course of the research were produced analyzers that aimed to mobilize the team to produce knowledge about their work process and oral health, such as the organization of an agenda of Oral Health; the team and one of their families: the case of the Sabiá Laranjeira Family and the discussion about the insertion of Oral Health in the Rubi Family Health Team. Have been identified crosscutting issue with the produced knowledge. One of them refers to relations among workers of the team, who considered it as a juxtaposition of knowledge and built on interpersonal relationships. Another expresses one of tensions that the team experienced with assistance, health care and extended clinic. These tensions are based on mismatches of supply and demand of services in unity and exclusive enhancement of the technological apparatus of health. The third issue is present in the alienation of work process, given by the fragmented perception of workers and users about the object of the production of health care. The last issue exposes tensions in the arena of Primary Health Care and Family Health Strategy according to the training of health professionals to work as a team. The Cartographic method enabled to follow the procesuality of the team and expose tensions present in their work process. It was found that the construction of a field of knowledge and practices for Oral Health Collective actions are in the process that is influenced by the tensions of daily work as a team, and that determines its configuration or not. However, at times when the interaction and articulation were built, was powerful to make qualified health practices.
\end{abstract}

Keywords: Health Care; Public Health Dentistry; Interdisciplinary; Family Health Program, Comprehensive Health Care 


\section{RESUMEN}

SILVEIRA, F. La práctica de la Salud Bucal en los equipos de Salud de la Familia. 2011. Tese (Doutorado) - Escola de Enfermagem de Ribeirão Preto, Universidade de São Paulo, Ribeirão Preto, 2011.

Esta investigación tiene como objetivo investigar las posibilidades y límites para la construcción de prácticas de Salud Oral en la producción del cuidado a la Salud por un Equipo de Salud de la Familia. La interacción del conocimiento y la articulación de acciones entre actores de diferentes disciplinas de salud pueden conducir a una relación interdisciplinar y conformar un campo de competencias y responsabilidades dirigidas para acciones de Salud Bucal Colectiva. El Ministerio de Salud ha enfatizado, junto con los equipos de salud, la adopción de prácticas interdisciplinares a través de políticas de Atención Básica a la Salud, Estrategia de Salud de la Familia y de las Directrices Nacionales de Salud Bucal. Se trata de un estudio cartográfico del cotidiano del equipo desde la perspectiva de la Investigación-Intervención y basada en el Movimiento Institucional. Se trabajó con datos primarios producidos en las reuniones del equipo administrativo y de discusión de casos de familia que fueron grabadas en audio y posteriormente transcritas. También fueron parte de los datos el diario de campo de las actividades de observación participante y de las reuniones del grupo de investigación y de estudio. En el curso del investigación fueron producidos analizadores que tuvieron el objetivo de movilizar el equipo para producir un conocimiento a respecto de su proceso de trabajo y de la Salud Oral, tales como la organización de la agenda de la Salud Oral; el equipo y una de sus familias: el caso de la familia del Sabiá Laranjeira y la discusión sobre la inserción de la Salud Oral en el Equipo de Salud de la Familia Rubi. Han sido identificados ejes transversales al del conocimiento producido. Uno de ellos se refiere a las relaciones entre los trabajadores del equipo, que la consideraran como yuxtaposición de saberes y construida a partir de las relaciones interpersonales. Otro expresa una de las tensiones que el equipo vivencia con asistencia, atención a la salud y clínica ampliada. Estas tensiones se basan en los desencuentros de la oferta y de la demanda de servicios en la unidad y en la valorización exclusiva del aparato tecnológico de la salud. El tercer eje se trata de la alienación presente en el proceso de trabajo, determinada por la percepción fragmentada de los trabajadores y usuarios a respecto del objeto de la producción del cuidado a la salud. El último eje expone las tensiones en el ámbito de la Atención Básica en Salud y de la Estrategia Salud de Familia en función de formación del profesional de la salud para el trabajo equipo. El método Cartográfico posibilitó acompañar la procesualidad del equipo y exponer tensiones presentes en su proceso de trabajo. He sido verificado que la construcción de un campo de conocimientos y prácticas vuelto para acciones de Salud Oral Colectiva se constituí en proceso influenciado por las tensiones del cotidiano del trabajo en equipo, y que determina su configuración o no. Sin embargo, en momentos en que la interacción y articulación fueron construidas se mostró potente para componer prácticas de salud más calificado.

Palabras clave: Cuidado a la Salud; Odontología en Salud Colectiva; Interdisciplinaridad; Programa Salud de la Familia; Atención Integral de Salud. 


\section{LISTA DE SIGLAS}

ABS - Atenção Básica à Saúde

ACS - Agente Comunitário de Saúde

AERP - Ambulatório Especializado de Ribeirão Preto

AL - Aluno

ALE - Aluno de enfermagem

ALM - Aluno de medicina

ALN - Aluno de nutrição

ALO - Aluno de odontologia

APS - Atenção Primária à Saúde

ASB - Auxiliar de Saúde Bucal

CADE - Centro de Apoio ao deficiente

CAP - Centro de Atenção Primária

CD - Cirurgião-dentista

CEDEM - Centro Especializado do Deficiente Mental

DO - Docente

EF - Enfermeiro

EMCD - Escola Municipal da Criança Deficiente

ESB - Equipe de Saúde Bucal

ESCD - Escola de Socialização da Criança Deficiente

ESF - Estratégia Saúde da Família

FI - Fisioterapia

FMRP - Faculdade de Medicina de Ribeirão Preto

FORP - Faculdade de Odontologia de Ribeirão Preto

IBGE - Instituto Brasileiro de Geografia e Estatística

MD- Médica

NSF - Núcleo de Saúde da Família

OPAS - Organização Pan-americana de Saúde

PA - Pesquisa Ação

PACS - Programa de Agentes Comunitários de Saúde

PANAN - Programa Ampliado de Atendimento ao Aprendiz Nacional

PI - Pesquisa Intervenção

PP - Pesquisa Participante

PS - Psicólogo

PSF - Programa de Saúde da Família

RFA - Residente em Farmácia

RFI - Residente em Fisioterapia

RMFC - Residente em Medicina de Família e Comunidade.

RNU - Residente nutrição

SMSRP - Secretaria Municipal da Saúde de Ribeirão Preto

SUS - Sistema Único de Saúde

TO - Terapeuta Ocupacional

TSB - Técnico de Saúde Bucal

UBS - Unidade Básica de Saúde

USF - Unidade de Saúde da Família

USP - Universidade de São Paulo 


\section{SUMÁRIO}

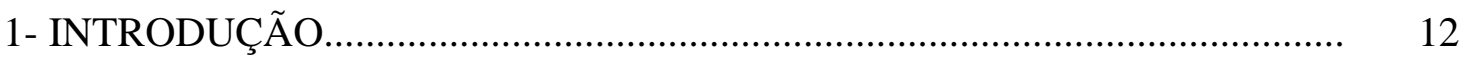

1.1- Apresentando a problemática e o recorte da pesquisa................................... 12

1.2- Equipe da Unidade da Saúde de Família Rubi: pensando a equipe como um dos eixos da construção da integralidade da atenção.

1.3- O núcleo de competência e de responsabilidade da Saúde Bucal - Saúde Bucal Coletiva............................................................................................... 20

1.4- As indagações no contexto da pesquisa...................................................... 26

1.5- O objetivo da pesquisa........................................................................... 27

2- OS CONCEITOS FUNDAMENTAIS DO ESTUDO: preparando o caminho... 28

2.1- Atenção Primária à Saúde/Atenção Básica em Saúde...................................... 28

2.2- Saúde Bucal na Estratégia Saúde da Família.................................................... 31

2.3- Trabalho em Equipe - elemento estruturante para o campo de competência e



3- CARTOGRAFANDO A SAÚDE BUCAL NA SAÚDE DA FAMÍLIA............ 41

3.1- Fazendo aproximação com a cartografia........................................................ 41

3.2- A opção pela Pesquisa Intervenção (PI)....................................................... 45

3.3- Uma aproximação com os conceitos da Análise Institucional/Movimento



3.3.1- As sociedades segundo a Socioanálise........................................................ 52

3.4- Construindo o campo de análise e de intervenção da Prática de Saúde Bucal na USF Rubi

3.5- Aspectos éticos necessários à entrada no campo e à realização da pesquisa.

3.6- Construindo as etapas da Pesquisa Intervenção

3.6.1- A sensibilidade da equipe da USF Rubi com questões de Saúde Bucal

3.6.2- Qual o desejo da equipe?

3.6.3- Analisadores

3.6.4- Diagnóstico provisório e planejamento preliminar. 
3.6.5- Diagnóstico de planejamento definitivo

4- OFERTANDO UMA VIAGEM SOBRE A DISCUSSÃO EM TORNO DA PRÁTICA DE SAÚDE BUCAL - MODULANDO A DEMANDA NAS EQUIPES.

4.1- Implicações do pesquisador. 68

4.2- Caminho empreendido e a constituição dos analisadores. 73

4.2.1- Revendo a agenda de Saúde Bucal da equipe da USF Rubi

4.2.2- A equipe e uma de suas famílias: o caso da família do Sabiá Laranjeira

4.2.3- Discutindo a Saúde Bucal com a equipe da USF Rubi....

5- CARTOGRAFANDO A EQUIPE DA USF RUBI. 84

5.1- Relações estabelecidas entre os atores disciplinares. 85

5.2- A assistência, a atenção e a clínica ampliada na equipe Rubi 89

5.3- Alienação no processo de produção de cuidado em saúde pela USF Rubi 108 5.4- A Saúde Bucal na arena da atenção básica em saúde e da Estratégia Saúde da Família.

6- CONSIDERAÇÕES FINAIS.

REFERÊNCIAS. 


\section{1- INTRODUÇÃO}

\subsection{Apresentando a problemática e o recorte da pesquisa}

Esta pesquisa é um estudo de caso a respeito dos saberes e das práticas que sustentam uma práxis específica no âmbito da saúde, a prática de Saúde Bucal em uma equipe de Saúde da Família. Este estudo insere-se nas atividades do Núcleo de Pesquisa e Estudos em Saúde Coletiva - NUPESCO e na linha de pesquisa Práticas, Saberes e Políticas de Saúde1.

A formulação do objeto da pesquisa, "A prática de Saúde Bucal em uma equipe de Saúde da Família”, está relacionada à trajetória profissional do pesquisador, que vem participando de dois grupos de trabalho multiprofissionais: a Unidade de Avaliação e Controle do Departamento Regional de Saúde de Ribeirão Preto e a unidade de atendimento a pacientes com AIDS no Centro de Saúde Escola do Sumarezinho da Faculdade de Medicina de Ribeirão Preto da Universidade de São Paulo (FMRP-USP). Esses serviços construíram sua história enquanto grupos de profissionais, tendo características de possuírem um objetivo comum, uma linguagem própria, uma divisão de trabalho com equidade e um projeto próprio, que era reconhecido pelos seus membros.

Por outro lado, chamavam atenção a localização física dos serviços odontológicos nas unidades de saúde e o isolamento das equipes de Saúde Bucal, em relação a outros grupos de trabalho na mesma unidade de saúde, o que demonstrava ausência de interação entre as áreas de saberes e das práticas da saúde. Uma possível interação criaria potencial para construção de práticas de Saúde Coletiva nas unidades.

Na vida acadêmica, houve uma primeira incursão no estudo das práticas na odontologia, cujo objeto de pesquisa foi o atendimento odontológico de pacientes com AIDS, que suscitou questões relacionadas à biossegurança, ao cuidado, à atenção à saúde, à responsabilidade profissional, à humanização, aos aspectos biopsicossociais da doença. O resultado desses estudos foi a dissertação de Mestrado "Prática Odontológica e a AIDS", cuja metodologia pertence à área da psicologia social.

\footnotetext{
${ }^{1}$ Linha de pesquisa vinculada ao Departamento de Enfermagem Materno-Infantil e Saúde Pública da Escola de Enfermagem de Ribeirão Preto da Universidade de São Paulo.
} 
Mais recentemente, atuamos junto a uma Unidade de Saúde da Família (USF), um serviço de saúde que busca construir um processo de trabalho em equipe do tipo integrador, ou, nos dizeres de Peduzzi (2001), um processo em que os trabalhadores esforçam-se para a conformação de uma equipe do tipo integração, que tem proporcionado uma compreensão mais aprimorada da integração entre seus diversos membros atuantes. Essa integração pode tornar possível o compartilhamento de saberes e práticas de disciplinas distintas da área da saúde e uma composição de projetos terapêuticos oferecidos à sua população adstrita. Por outro lado, tornaram-se mais evidentes as dificuldades da integração de parte dos saberes da Saúde Bucal aos saberes das outras áreas da saúde, o que impediu a criação de um campo de conhecimento e de práticas comuns a todos os profissionais da equipe, o que podemos denominar de campo de Saúde Bucal Coletiva.

\subsection{A Equipe da Unidade de Saúde da Família Rubi: pensando a equipe como um dos eixos da construção da integralidade da atenção}

A Unidade de Saúde da Família Rubi (USF Rubi), vinculada à Universidade de São Paulo e localizada no Distrito Oeste do município de Ribeirão Preto, é o local onde exercemos a função de cirurgião-dentista (CD) desde a criação da unidade, no ano de 2001.

A USF Rubi foi instalada em uma chácara que possui um espaço interno adequado para a organização da assistência à saúde, contando, entre outras dependências, com quatro consultórios, sala para reuniões e grupos com usuários da unidade. No espaço externo, há uma quadra de esportes e um jardim arborizado, um espaço agradável que possibilitou, logo no início das suas atividades, abrigar e criar ações de promoção à saúde, tais como atividades físicas, Festa Junina, exposição de talentos, cursos de cabeleireiro, biscuit e dança.

A equipe da USF Rubi é composta por profissionais de diferentes formações na área da saúde; portanto, o grupo é multiprofissional e possui um objetivo comum, o de responsabilizar-se pela saúde das famílias residentes em sua área de referência, segundo as diretrizes da Estratégia Saúde da Família, formuladas pelo Ministério da Saúde (BRASIL, 1994; 2000b). A equipe planeja suas ações a partir das necessidades de saúde da sua comunidade, que é essencialmente constituída por pessoas adultas e idosas, que têm a depressão como um dos agravos mais frequentes.. 
Um dos disparadores para a organização do trabalho da equipe são as reuniões, que contam com a participação de todos os profissionais. Essas reuniões são destinadas à: discussão de casos de famílias, à organização da unidade e à educação permanente. Os membros da equipe alternam-se na coordenação das reuniões. A reunião administrativa é registrada em ata e as observações sobre as famílias são registradas no prontuário da família, e discutidas pela equipe. A liderança desses encontros é exercida pelo profissional que apresenta a família ou o assunto para discussão, seja ele técnico ou administrativo.

Peduzzi (2001), em relação à conformação do trabalho em equipe na saúde, apresenta os elementos básicos para a distinção dos tipos de trabalho em equipe, caracterizando-os segundo o processo de trabalho instituído, podendo ser do tipo integração ou agrupamento. Segundo a autora, o trabalho em equipe do tipo agrupamento implica justaposição de ações e é caracterizado pela fragmentação da atenção à saúde e o trabalho em equipe do tipo integração permite a articulação das ações e a interação dos agentes, caracterizadas pela construção de possibilidades de recomposição dos saberes e dos trabalhos especializados. Assim, cada categoria profissional participa com seu núcleo de competência e responsabilidade e, ao mesmo tempo, todos contribuem para a construção de um campo de competência que seja comum à equipe e que poderia ser pensado em torno da construção do campo de Saúde Coletiva.

Os conceitos de campo e núcleo podem ser encontrados nos textos de Campos, Chakour e Santos (1997) e Campos (2000). Núcleo de competência e responsabilidade diz respeito a uma especificidade, a atribuições exclusivas de uma especialidade que delimita uma área de saberes e práticas, formada pela aglutinação de conhecimento e a conformação de um determinado padrão concreto de compromisso com a produção de valores de uso. O campo de competência e responsabilidade é uma área mais geral, sem limites delimitados, e que inclui os principais saberes de especialidades raízes, gerando um espaço de interação de disciplinas, um espaço entre disciplinas, em que atores sociais de cada disciplina ou profissão buscariam, em outras disciplinas, apoio para cumprir suas tarefas teóricas e práticas, conformando uma nova práxis. Contudo, a conformação desses espaços seria um processo contínuo de negociações, em vista da impossibilidade de serem arbitradas somente pela racionalidade técnica, definidas por normas e diretrizes. No entanto, estão presentes nessa arena interesses políticos, profissionais e pessoais.

Esse movimento entre disciplinas para a conformação de um campo de competências também pode ser compreendido pelo conceito de interdisciplinaridade. Almeida Filho (1997) 
diz que na interdisciplinaridade há reciprocidade e enriquecimento mútuo entre as disciplinas, com uma tendência à horizontalização das relações de poder entre campos implicados, o que leva a uma fecundação e aprendizagem mútua, que somente se efetuam por uma recombinação dos elementos internos.

Na mesma direção, Peduzzi (2001) salienta as características que devem ser desenvolvidas pela equipe para desempenhar um trabalho do tipo integração. A comunicação entre os agentes do trabalho é praticada como dimensão intrínseca ao trabalho em equipe e há uma elaboração de linguagens comuns, objetivos comuns, propostas comuns, ou mesmo de uma cultura comum, cujas finalidades são interagir e, nesse processo, construir consensos pertinentes a cada contexto. Dessa forma, a comunicação, com o estabelecimento de uma linguagem comum e o estabelecimento de sentidos e significados para a equipe na obtenção de consensos possíveis, é um dos elementos para a constituição da equipe de integração.

O reconhecimento da construção de dispositivos que funcionem como sinalizadores de sua integração pela equipe pode se constituir em um eixo em torno do qual se dá a dinâmica cotidiana de trabalho e de interação e pode estar materializado pelo projeto de cuidado à saúde específico para cada equipe e direcionado para um plano de ação diante de uma situação concreta de trabalho. Nesse movimento, a equipe esforça-se para reconhecer, na sua prática, o projeto assistencial hegemônico dominante, para, em seguida, reelaborar a sua práxis. A divisão do trabalho deve buscar a menor desigualdade entre os diferentes trabalhos e os respectivos agentes, proporcionando maior integração na equipe e, à medida em que o trabalho em equipe é construído, efetivamente, na relação intrínseca entre trabalho e interação, tornam-se possíveis as oportunidades de os trabalhadores interagirem em situações livres de coação e de submissão, na busca de consensos acerca da finalidade e do modo de executar o trabalho (PEDUZZI, 2001).

A relação entre as especificidades dos trabalhos especializados e a flexibilidade da divisão do trabalho deve contemplar a coexistência de ações privativas das respectivas áreas profissionais e das ações que são executadas, indistintamente, por agentes de diferentes campos de atuação. Ou seja, os profissionais realizam intervenções próprias de suas respectivas áreas, mas também executam ações comuns, nas quais estão integrados saberes provenientes de distintos campos. Quanto à autonomia técnica, há complementaridade e colaboração no seu exercício e não há independência dos projetos de ação de cada agente.

Um dos grandes desafios postos às equipes de Saúde da Família é a organização do trabalho de equipe, para que se constitua em uma equipe de integração. A equipe da USF 
Rubi possui atividades que são importantes para a organização do trabalho da equipe. Uma delas é a reunião de discussão de casos de família, que ocorre duas vezes por semana e que conta com a participação de todos os seus membros. Essa reunião também comunica à equipe novos cadastros de famílias. Uma nova família é cadastrada a partir de uma caracterização das informações obtidas com a visita domiciliar para cadastramento e com a Ficha A2 do SIAB (BRASIL, 1998), seguida pela classificação de risco para as famílias (VIEIRA, 2001). Na reunião também discutem-se casos de famílias em que haja alguma modificação, isto é, uma nova situação de saúde ou condição social que mostre a melhora ou o agravamento de quadros anteriores. Essas discussões determinam nova avaliação e/ou nova conduta na organização do cuidado desenvolvido pela equipe.

Como a USF Rubi é vinculada à Universidade de São Paulo (USP), ela não apresenta as características estritas presentes nas regulamentações do Ministério da Saúde para Saúde da Família (BRASIL, 2001). A unidade conta com a figura do coordenador, que, em geral, é um docente ligado à USP e que participa das reuniões e de outras atividades acadêmicas desenvolvidas na unidade. Contudo, as discussões são lideradas pelo profissional que tem maior proximidade com a família ou por aquele que apresentou o caso Nesse processo, os agentes comunitários de saúde têm uma liderança expressiva.

A equipe reconhece que as reuniões são momentos fundamentais para a discussão das casos das famílias; são momentos que asseguram a participação de todos os trabalhadores e possibilitam a contribuição de cada um para a compreensão do processo de saúde-adoecimento e para a construção dos projetos terapêuticos para as famílias ou grupos com risco comum da comunidade.

Nesses oito anos de atividade na USF Rubi, houve uma busca intensa pela construção do espaço de organização do trabalho, em que, atualmente, pode-se notar a incorporação de uma forma própria de organização, que inclui o reconhecimento unânime desse espaço, o consenso em torno da necessidade de não citar nomes de membros das famílias discutidas para evitar a exposição dos pacientes e o ajuste da proposta da Estratégia Saúde da Família do Ministério da Saúde à realidade local.

Outra atividade fundamental no processo de trabalho da USF Rubi são as reuniões administrativas, momento em que ocorrem a organização do trabalho e da unidade de saúde, a

\footnotetext{
${ }^{2}$ A ficha A é a ficha de cadastro da família que dispara o processo de acompanhamento pela equipe de Saúde da Família.
} 
elaboração de propostas coletivas de trabalho e a resolução de conflitos internos à equipe. Cabe, aqui, salientar que a coordenação da unidade reconhece o momento da reunião como legítimo para a organização do processo de trabalho da equipe.

Ayres (2009, p. 3), ao discutir a organização das ações de atenção à saúde, modelos e práticas, remete ao princípio de integralidade do Sistema Único de Saúde (SUS). “ a integralidade nos desafia a saber e fazer o "que" e "como" pode ser realizado em saúde para responder universalmente às necessidades de cada um”. O autor aponta quatro eixos--necessidades, finalidades, articulações, interações-- que nos ajudam a compreender as diversidades e tensões no cotidiano da atenção à saúde, com base na ideia de integralidade.

$\mathrm{O}$ primeiro é o eixo das necessidades, que diz respeito à qualidade e à natureza da escuta, acolhimento e resposta às demandas de atenção à saúde. Trata-se de desenvolver sensibilidade e capacidade de resposta às necessidades que vão além da prevenção, da correção e recuperação de distúrbios morfológicos ou funcionais do organismo, mas sem descuidar destas (AYRES; 2009).

Neste ponto, a questão que surge é se os diversos atores da equipe de Saúde da Família possuem sensibilidade para os problemas da boca: dor, lesão em mucosa, sorriso feio ou mau hálito. E, havendo essa sensibilidade, pergunta-se, também, qual é a percepção da responsabilidade da demanda em relação aos problemas e quais são os instrumentos disponíveis ou que deveriam estar disponíveis a esses profissionais para lidar com essa demanda?

O segundo eixo trata das finalidades e diz respeito a graus e modos de integração entre as ações de promoção da saúde, prevenção dos agravos, tratamento de doenças e sofrimentos e recuperação da saúde/reinserção social (AYRES, 2009). Aqui, o objetivo é criar sinergismos que aprimorem o desenvolvimento das ações, tanto da perspectiva da racionalização meiosfins, como do conforto e conveniência para indivíduos, famílias e comunidades.

Há evidências de que os agravos à saúde e à Saúde Bucal tenham fatores de risco em comum (SHEIHAM, MOYSÉS, 2000; SHEIHAM, WATT, 2000). Um determinado hábito de viver pode levar ao desenvolvimento de várias doenças ou agravá-las, como ocorre com quem possui uma dieta de alto consumo de açúcar refinado e baixo teor de fibras, o que pode levar o indivíduo a desenvolver ou agravar diabetes mellitus, hipertensão arterial, doenças cardíacas, cárie dentária e obesidade. A abordagem por meio dos fatores de risco comuns pode potencializar medidas de prevenção, construção de políticas saudáveis, criação de ambientes que apoiem escolhas saudáveis, fortalecimento de ações comunitárias, desenvolvimento de habilidades de autocontrole e autonomia pessoal para práticas de autocuidado em higiene e saúde, e reorientação 
de serviços odontológicos, compondo um campo de competência e responsabilidade para o trabalho na Atenção Básica/Saúde da Família.

O terceiro eixo é o das articulações e diz respeito aos graus e modos de composição de saberes interdisciplinares, equipes multiprofissionais e ações inter-setoriais no desenvolvimento das ações e estratégias de atenção à saúde (AYRES, 2009). O propósito é criar as melhores condições para oferecer resposta efetiva às necessidades de saúde em uma perspectiva ampliada. Esse eixo está presente nos princípios da Estratégia Saúde da Família, proposta pelo Ministério da Saúde (BRASIL, 2000; 2004), e aponta que a Atenção Básica tem como foco principal as famílias e a comunidade, sob responsabilidade de uma equipe multiprofissional, cujo processo de trabalho deve ser pautado pela interdisciplinaridade e pelo planejamento estratégico.

O último eixo, a natureza e a qualidade das interações na prática do cuidado, trata da construção de condições efetivamente dialógicas entre sujeitos participantes dos encontros relacionados à atenção à saúde, seja de pessoa a pessoa, seja na perspectiva de equipes/comunidades, sem que as aspirações dos eixos anteriores não possam ser realizadas (AYRES, 2009).

Um sujeito pode construir vínculos diferentes com cada ator de uma equipe de saúde, segundo afinidades pessoais. Em função disso, o sujeito pode relatar o seu agravo à saúde à aquele com quem tiver maior vínculo, não necessariamente àquele profissional cuja disciplina lhe proporcione um núcleo de saberes e competências para o acompanhamento de sua saúde.

Diante disso, surgem duas prerrogativas para o trabalho em equipe: a primeira refere-se à escuta, que está vinculada à sensibilidade e à capacidade de dar respostas, determinada pelo vínculo profissional/pessoa, profissional/comunidade, equipe/comunidade e a segunda, à existência de um espaço em que as demandas originadas da escuta sejam postas em discussão para elaborar projetos terapêuticos, a partir das necessidades de saúde expressas pelos usuários.

Campos, Chakour e Santos (1997), discutindo a equipe de saúde, diz que a crescente especialização diminui a capacidade resolutiva do cuidado à saúde e aumenta a alienação dos profissionais em relação aos resultados de suas práticas. Torna-se difícil, segundo o autor, nessa situação, identificar quem se responsabiliza pelo resultado global do atendimento. Mesmo quando há uma equipe multiprofissional, esse arranjo organizacional, por si só, não garante a produção da integralidade do cuidado. Esse é, certamente, um desafio vivido pela equipe da USF Rubi.

Assim, nesse processo de construção do trabalho em equipe na USF Rubi, algumas questões postas em discussão já parecem ser tratadas de uma maneira mais integradora, a 
exemplo das atividades coletivas de controle da dengue, vacinação de idosos, grupo de reeducação alimentar e cuidados básicos com acamados. Embora os saberes relacionados à Saúde Bucal sejam valorizados pelos profissionais da equipe de Saúde da Família e estejam presentes nas discussões de casos de famílias e nas reuniões administrativas, sua incorporação na prática da equipe é ainda incipiente, sendo que a sensibilidade e capacidade de resposta aos cuidados de Saúde Bucal, assim como o desencadear de ações, são reconhecidas como responsabilidades exclusivas do dentista. As situações existentes na USF acabam sendo remetidas a este profissional para sua resolução.

Campos, Chakour e Santos (1997, p. 248) considera que "o desafio seria combinar graus de polivalência com certo nível necessário e inevitável de especialização" pelas equipes. Assim, no que diz respeito à aplicação dos conceitos de campo e de núcleo de competência e responsabilidade, seja na formação ou na prática profissional, "o núcleo marcaria, dessa forma, a diferença entre os membros de uma equipe. Por campo ter-se-iam saberes e responsabilidades comuns ou confluentes a várias profissões ou especialidades" (CAMPOS, CHAKOUR E SANTOS, 1997, p.248).

Segundo Ferreira (2010), o significado de medicina é o da arte e ciência de evitar ou curar doença. Por sua vez, a odontologia é a parte da medicina que se ocupa da higiene, do tratamento e da profilaxia das doenças dentárias e conjunto de ciências que se estudam para o exercício da profissão de cirurgião-dentista (CD). Assim se pode delimitar o núcleo de competência da odontologia. Na maioria dos países europeus, a odontologia é uma especialidade da área médica. Já nos países americanos, a odontologia constitui-se em uma área de conhecimento distinto, exercida pelo $\mathrm{CD}$, cuja regulamentação da profissão tem o seu marco histórico na Reforma Sabóia, que institucionaliza os cursos de odontologia por meio do Decreto $\mathrm{n}^{\circ}$ 9.311, de 2 de outubro de 1884. A partir dessa data,, a odontologia passou por um processo de formação de um núcleo de saberes e práticas voltado para o cuidado de um aparelho do corpo humano, denominado estomatognático (SILVA; SALES-PERES, 2007).

Como já apontado anteriormente, uma das possibilidades que se coloca para pensarmos do ponto de vista prático este conceito de campo refere-se à abordagem por meio dos fatores de risco comuns às distintas áreas profissionais (medicina, odontologia, enfermagem, por exemplo), assim como o aprendizado da leitura de necessidades de saúde, compondo um campo de competência para a Saúde Bucal. 


\subsection{O núcleo de competência e de responsabilidade da Saúde Bucal - Saúde Bucal Coletiva}

A odontologia manteve-se, até o final do século passado, restrita a um modelo de assistência denominado "Odontologia de Mercado", caracterizado pelo trabalho privado, autônomo, em consultórios isolados e independentes. $\mathrm{O}$ ensino, a pesquisa e a assistência odontológica eram centrados no trabalho cirúrgico-restaurador, na assistência individual. Era presente, portanto, de forma majoritária na prática privada. A partir do início do século XX, a odontologia foi inserindo-se gradualmente no serviço público de saúde e construindo seus modelos de assistência e, às vezes, de atenção à Saúde Bucal (NARVAI, 2006).

Chaves (1977), que possuía formação acadêmica em medicina e odontologia, escreveu um livro que se tornou referência para a odontologia e para a prática da odontologia sanitária, a partir da década de 1960. Nele, o autor conceitua Saúde Bucal como estado de harmonia, normalidade ou higidez da boca e que só tem significado quando acompanhada, em grau razoável, da saúde geral do indivíduo. O conceito de Saúde Bucal é uma abstração útil, ao considerarmos que saúde é um estado do indivíduo que não pode subsistir com saúdes parciais dos diversos órgãos e sistemas. O emprego de Saúde Bucal é justificado para facilitar a identificação de objetivos parciais em modelos de atenção à saúde, desde que não se perca de vista a limitação deste conceito, pois o autor centra a conceituação de saúde na perspectiva multicausal, não considerando a determinação social do processo saúde-doença. Contudo, cabe ressaltar sua importância ao assinalar-se a relação do estado geral de saúde do indivíduo com a sua Saúde Bucal.

Durante os anos de 1980, foi acrescido à expressão "Saúde Bucal" o termo "coletiva", porque parte dos profissionais e intelectuais da área da Saúde Bucal afiliaram-se ao movimento da Saúde Coletiva e dele receberam uma grande influência. Dessa forma, a Saúde Bucal Coletiva assume as ciências sociais como categoria analítica, com o propósito de romper com o assistencialismo odontológico e, ao mesmo tempo, construir uma referência teórica para as ações de Saúde Bucal (NARVAI, 1994).

No campo da Saúde Bucal Coletiva, há uma permanente discussão em torno dos polos curativo e preventivo presentes na prática de Saúde Bucal. Narvai (1992) explora essa polaridade ao diferenciar assistência e atenção à Saúde Bucal. Assistência está restrita ao campo odontológico, à recuperação da Saúde Bucal por meio de ações cirúrgicorestauradoras, dirigidas a consumidores individuais, o que tem reconhecimento pelo seu 
desenvolvimento científico-tecnológico e pela contribuição para alcance de melhores níveis de Saúde Bucal do conjunto da população, garantindo competência técnica no alívio do sofrimento e obtenção de conforto, o que é imprescindível para garantir a integralidade da prática odontológica (NARVAI, 1992). Entretanto, o autor chama atenção para o fato de que questionamentos têm sido motivados a respeito da sua capacidade de curar a cárie dentária, constituindo-se em críticas ao denominado "paradigma cirúrgico-restaurador".

Por outro lado, a atenção à Saúde Bucal é constituída por um conjunto de ações que inclui a assistência odontológica individual e busca atingir grupos populacionais por meio de ações coletivas com o objetivo de manter a Saúde Bucal. Essas ações podem acontecer em outros setores, a exemplo da geração de empregos, renda, habitação, saneamento e lazer ou até mesmo internamente à área odontológica, como no caso da difusão em massa de informações, ações educativas, controle de dieta e medidas de higiene bucal. Dessa forma, a atenção à Saúde Bucal tem como objetivo atuar nos determinantes do processo saúde-doença, o que gera a necessidade de ações em áreas que estão além da odontologia, requerendo articulação e coordenação de ações multissetoriais (NARVAI, 1992).

O paradigma da atenção à Saúde Bucal proporcionou mudanças nos agentes sociais, no processo de trabalho e no objeto da prática odontológica, incluindo as alterações no ambiente de trabalho, onde o antigo gabinete dentário foi substituído por outros espaços de trabalho, a exemplo das clínicas modulares. Abandonou-se o trabalho isolado e incluíram-se outros sujeitos do processo de trabalho, tal como o auxiliar e o técnico de Saúde Bucal.

Botazzo (1989) afirma que, nesse processo de construção de uma nova prática da odontologia, a Saúde Bucal Coletiva é um campo que, à medida em que a odontologia vai se tornando cada vez mais integral, vai também se tornando cada vez menos odontologia. O autor diz que a essência da questão está na compreensão de que a prática ou assistência odontológica às pessoas limita-se às ações clínicas e cirúrgicas direcionadas ao indivíduo. Já a atenção à Saúde Bucal incorpora a prática odontológica às ações sobre as causas das doenças, sejam estas de natureza biológica, social, econômica ou política. Portanto, situa-se num campo extraclínica, englobado por práticas de saúde e de outros setores sociais e não mais no campo estrito da assistência odontológica.

Segundo esses aspectos, pode-se dizer que o campo conformado no processo de trabalho de equipes de saúde, a exemplo da Estratégia Saúde da Família, formado pela integração de práticas de saúde, de um conhecimento próprio da odontologia e intermediado 
pelo da Saúde Coletiva, que tem nas ciências sociais uma de suas categorias analisadoras, pode ser denominado de campo de Saúde Bucal Coletiva.

O Ministério da Saúde criou um incentivo financeiro para a inserção de equipes de Saúde Bucal no Programa Saúde da Família (BRASIL, 2000a) e propôs diretrizes para essa inserção, especificando as atribuições de todos os membros da equipe de Saúde da Família a respeito da Saúde Bucal, mas não avançou na construção de um processo de trabalho em equipe (BRASIL, 2001), o que trouxe um desafio para o campo da Saúde Bucal Coletiva. Mais adiante, o Ministério da Saúde, por meio das Diretrizes da Política Nacional de Saúde Bucal (BRASIL, 2004), aponta que, para a adequação do processo de trabalho em Saúde Bucal, fazem-se necessários:

Interdisciplinaridade e Multiprofissionalismo: a atuação da equipe de Saúde
Bucal (ESB) não deve se limitar exclusivamente ao campo biológico ou ao trabalho
técnico-odontológico. Ademais de suas funções específicas, a equipe deve interagir
com profissionais de outras áreas, de forma a ampliar seu conhecimento, permitindo
a abordagem do indivíduo como um todo, atenta ao contexto socioeconômico-
cultural no qual ele está inserido. A troca de saberes e o respeito mútuo às diferentes
percepções devem acontecer permanentemente entre todos os profissionais de saúde
para possibilitar que aspectos da Saúde Bucal também sejam devidamente
apropriados e se tornem objeto das suas práticas. A ESB deve ser - e se sentir -
parte da equipe multiprofissional em unidades de saúde de qualquer nível de atenção
(BRASIL, 2004, p. 6).

A fim de procurar contemplar essas premissas, no momento da conformação das equipes das USFs pela Universidade de São Paulo e em vista do entendimento por parte dos profissionais e pelo serviço, optamos pela presença de um dentista que pudesse fazer a aproximação com as questões de Saúde Bucal, mesmo sem a equipe preconizada pelo Ministério da Saúde (BRASIL, 2004), de modo a buscar o fortalecimento da Atenção Básica e criar a possibilidade de as USFs serem campo de estágio para formação acadêmica e de pósgraduação na área de odontologia.

Do ponto de vista do ensino, esses serviços de Saúde da Família constituem-se espaços para formação de alunos de diferentes cursos da área da saúde. No caso do curso de Odontologia3, desde o primeiro ano de graduação, os alunos se fazem presentes com atividades curriculares, que se iniciam no primeiro ano, com o reconhecimento da área de cada USF ligada à USP, e no segundo, com a elaboração de um diagnóstico de saúde. Ambas as atividades têm duração de uma semana, em horário integral. No terceiro ano, realizam-se atividades de educação em saúde e levantamento epidemiológico em espaços sociais. No

\footnotetext{
${ }^{3}$ Aqui trata-se especificamente do curso de Odontologia desenvolvido pela Faculdade de Odontologia de Ribeirão Preto da Universidade de São Paulo.
} 
quarto ano, passa-se por uma imersão no trabalho de uma das equipes de Saúde da Família, por um período de quatro semanas, com jornada de 30 horas semanais. Nesse caso, a atribuição do aluno é exercer as funções de um CD na unidade.

As cinco USFs vinculadas à USP e localizadas na área básica da UBDS Citrino continuam possuindo apenas dentistas inseridos em suas equipes. As USFs Prata e USF Rubi contam com um $\mathrm{CD}$, com jornada de trabalho de 40 horas, com vínculo empregatício com a Faculdade de Odontologia de Ribeirão Preto - USP, a qual supervisiona as atividades dos alunos do quarto ano. As USF Safira e USF Onix possuem um CD, cada um com jornada de trabalho de 24 horas, que realiza assistência odontológica e supervisiona as atividades dos alunos, com vínculo empregatício com a Faculdade de Medicina de Ribeirão Preto - USP. A USF Esmeralda possui também um CD, que possui jornada de 40 horas de trabalho semanal, está vinculado à Secretaria Municipal de Saúde de Ribeirão Preto e realiza atividades de assistência e supervisão dos alunos.

As atividades restauradoras e cirúrgicas são realizadas nos cinco consultórios da UBDS Citrino, que possui três atendentes de consultório dentário que participam do atendimento dos pacientes da área de abrangência das USFs ligadas à USP.

A distribuição das atividades dos profissionais e dos alunos guarda relação com o que é preconizado pelo Ministério da Saúde (BRASIL, 2004): 70\% da carga horária são destinadas a atividades clínicas (consultas e ações cirúrgicas restauradoras) e o restante da jornada de trabalho é destinado a atividades na USF, seja na participação em reuniões de discussão de casos de famílias e de organização da unidade, em atividades de grupo e ações de prevenção na unidade de saúde, seja na comunidade ou consulta de saúde. 


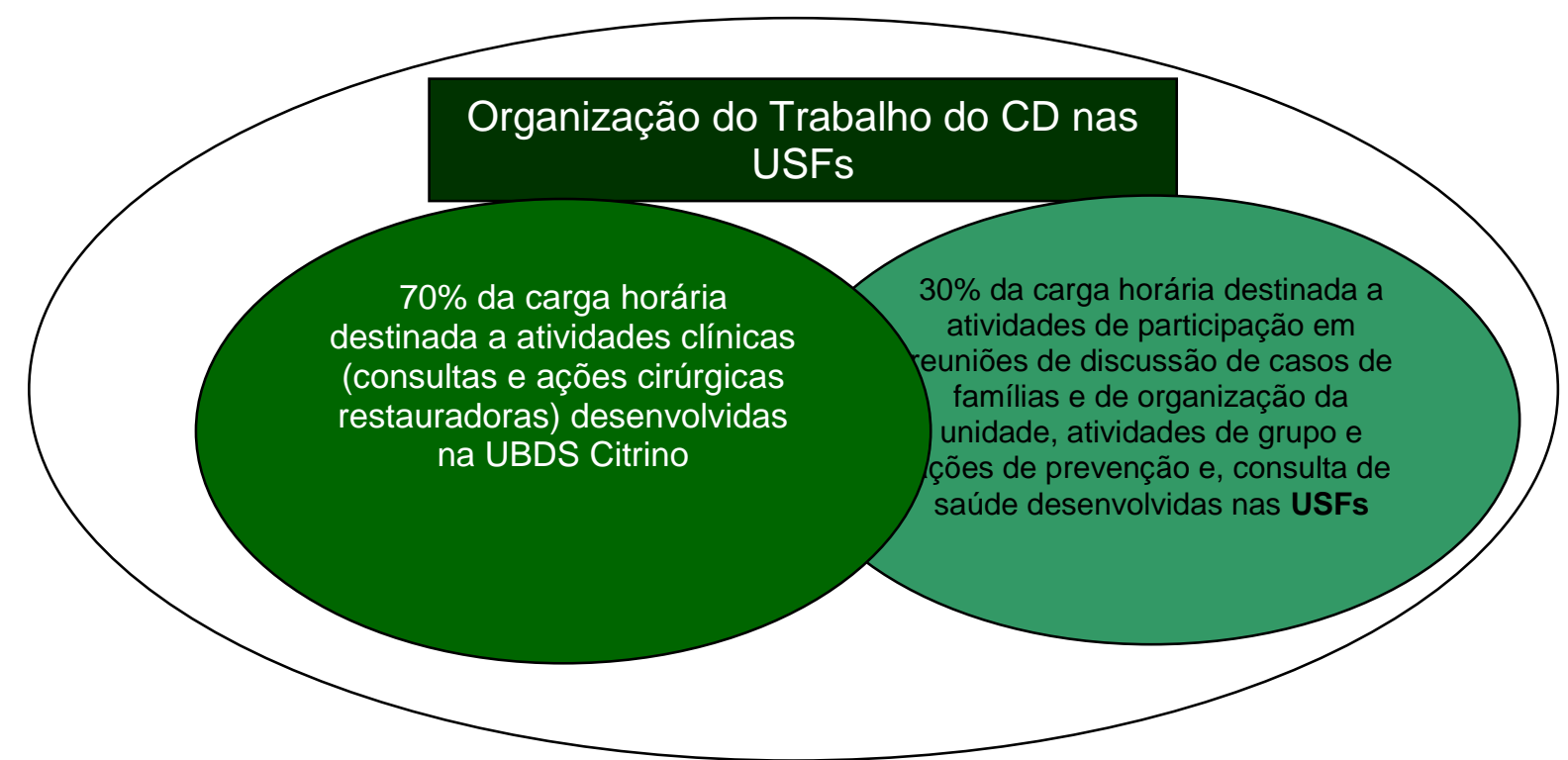

Figura 1: Representação esquemática da organização do trabalho do CD nas USFs da UBDS Citrino. Ribeirão Preto, 2011

Os usuários da USF Rubi têm como porta de entrada para atenção à Saúde Bucal o agendamento para o Grupo de Saúde Bucal, o serviço de urgência odontológico e as interconsultas geradas durante o atendimento realizado por outros profissionais da unidade. $\mathrm{O}$ agendamento para grupo é realizado por todos os profissionais da equipe e tem como objetivos formar um grupo de usuários que iniciam seguimento odontológico, estabelecer um contrato de convivência, proporcionar trocas de experiências entre os usuários e informar aos pacientes a Estratégia Saúde da Família (ESF) e a atenção em Saúde Bucal. O grupo ocorre uma vez a cada quatro semanas, com a participação e colaboração de outros membros da equipe, e todos os usuários são agendados para as consultas clínicas, individuais ou para a família.

A consulta tem as finalidades de criar vínculo profissional-paciente-família; conhecer a família, sua dinâmica e relações de afetividade; conhecer as condições de saúde do(s) membro(s) familiar(es) em tratamento; conhecer os motivos que levaram o usuário a procurar o atendimento odontológico, além de motivá-lo a perceber sua boca e falar sobre ela; estabelecer um status do risco para os agravos de Saúde Bucal; compor um plano de tratamento visando à prevenção e à recuperação da Saúde Bucal e desenvolver as ações de prevenção que não necessitem do recurso do equipamento odontológico. Paralelamente ou no término dessa fase, conforme a necessidade de tratamento do usuário ou da estratégia de 
motivação para adesão à proposta de seguimento, os usuários são agendados para tratamento restaurador-cirúrgico nos consultórios odontológicos da UBDS Citrino.

O pronto-atendimento odontológico funciona na UBDS Citrino e tem a finalidade de resolver as necessidades de tratamento imediato e urgências, tais como realização de restaurações extensas em dentes anteriores, cimentação e reparos em próteses, diagnóstico e intervenção em lesões bucais, abscessos e dor de dente. O usuário pode acessar o serviço de urgência durante o dia, por meio do encaixe na agenda, ou no período vespertino, que é exclusivo para essas situações.

As interconsultas são destinadas ao acompanhamento dos casos seguidos por outros profissionais e que necessitam de uma avaliação rápida, sendo muito frequentes os casos de lesões bucais. São realizadas em conjunto com médicos e enfermeiros. Quando uma situação identificada por qualquer profissional requer atendimento imediato, os profissionais de saúde, que não um $\mathrm{CD}$, tem acesso direto ao agendamento da USF, à UBDS Citrino ou ao prontoatendimento.

As questões que necessitam do compartilhamento com a equipe para a sua compreensão e construção de projetos terapêuticos podem ser remetidas às discussões de casos de família. Essa é uma conduta que tende à se tornar uma prática comum entre os profissionais da equipe.

Nessa atividade, percebemos que o conhecimento sobre a relação entre o modo de vida das pessoas, riscos para as doenças e as ações para seu controle estão presentes em um campo de competência, ou seja, é comum aos membros da equipe. Os profissionais reconhecem que o CD está integrado à equipe, compondo as discussões de casos de família em busca da compreensão do processo saúde-doença das famílias e a elaboração de estratégias individuais e coletivas, cujo objetivo é proteger, promover ou recuperar a saúde da população adstrita.

Porém, esse campo de competência comum à equipe está restrito a problemas que não são específicos da área de Saúde Bucal. Parte do saber relacionado à Saúde Bucal não faz parte dessas práticas desenvolvidas nas USFs, a ponto de possibilitar a construção coletiva de uma prática de Saúde Bucal, mesmo a equipe reconhecendo que há relação direta entre os agravos de saúde e os de Saúde Bucal ou que ambos tenham os mesmos riscos em comum. Dessa forma, quando há um problema de Saúde Bucal em uma das famílias em discussão, ele é remetido ao $\mathrm{CD}$, para que se informe e/ou apenas se organize o projeto terapêutico necessário. Embora a equipe da USF Rubi manifeste interesse pelos assuntos de Saúde Bucal 
relacionados a medidas de prevenção ou curativas, esee saber não é utilizado para compor um campo de conhecimento no planejamento dos projetos terapêuticos.

Situação semelhante foi observada pelos docentes da disciplina de Saúde Bucal do $2^{\circ}$ Curso de Especialização em Saúde da Família, em 2005, realizado pelo Polo de Educação Permanente em Saúde do Nordeste Paulista, para profissionais médicos, enfermeiros, cirurgiões-dentistas,, psicólogos e biólogos em Ribeirão Preto, São Paulo. Sua proposta foi construir, coletivamente, o campo de conhecimento em Saúde Bucal sobre as principais doenças bucais e medidas de prevenção, a partir da leitura e discussão de textos em grupos multiprofissionais. Havia uma tarefa de conclusão, que foi pactuada com o grupo, logo no início da disciplina, que era a elaboração de um consenso para as equipes de Saúde da Família a respeito dos riscos comuns e medidas de prevenção para doenças bucais e sistêmicas. Essa tarefa foi desenvolvida com muita dificuldade e observou-se desconforto dos CDs por haver outros profissionais lidando com um saber que até então era restrito a eles. Por outro lado, verificamos que os outros profissionais tinham o mesmo desconforto ao discutirem algo que não era de seu núcleo de competência e que, até aquele momento, era tratado como "isso é coisa do dentista", conforme relatado na avaliação final do curso. Tais questões contextualizadas, a partir de uma prática de produção de cuidados e de produção de processos de ensinoaprendizagem, levam à construção de indagações presentes neste estudo.

\subsection{As indagações no contexto da pesquisa}

Essas duas experiências relacionadas à ESF, uma ligada à prática profissional e a outra à formação, levam-nos a perguntar: 1) quais são os motivos de resistência dos profissionais não CDs em incorporar parte dos conhecimentos de Saúde Bucal como campo de competência das equipes na ESF?; 2) a resistência por parte dos profissionais não CDs pode estar na crença de que a criação de um campo de competência resultaria em acúmulo de atividade à sua rotina de trabalho; 3) existiria um constrangimento por parte dos CDs com a possibilidade da "perda de autonomia", poder, prestígio social, monopólio do saber ou descaracterização da profissão?

Definir quais conhecimentos de Saúde Bucal poderiam ser apropriados pela equipe e como sensibilizar esses profissionais para a incorporação desses conhecimentos como parte da prática de Atenção Básica são atitudes que, se tomadas, podem contribuir para o seu 
fortalecimento. Portanto, esta investigação refere-se a um estudo das possibilidades de construção de um campo de competência e responsabilidade de Saúde Bucal, que se caracterize pela interação de saberes e articulação de ações no cuidado à saúde. Nesse movimento, há preocupação em analisar qual o interesse da equipe em obter, construir e lidar com tal conhecimento para incorporar a Saúde Bucal nos projetos terapêuticos da Atenção Básica em Saúde.

A realização desta investigação possibilitará melhorar a qualidade da atenção à saúde prestada pelas equipes de referência em Saúde da Família, por meio da potencialização das ações de promoção de saúde, do enriquecimento das práticas de saúde e de Saúde Bucal e da construção coletiva de critérios de risco, projetos terapêuticos e consensos de intervenções. Também produzirá um conhecimento que poderá subsidiar a discussão acadêmica a respeito das alterações curriculares que vêm ocorrendo nos cursos de odontologia e que têm priorizado a formação segundo os princípios do SUS e da Atenção Básica à Saúde.

Por fim, a produção de conhecimento sobre a construção do campo de competência e responsabilidade e a divulgação dessa vivência poderá incentivar outras Equipes de Saúde da Família a percorrerem um processo de construção interdisciplinar da gestão do cuidado e da unidade de saúde, contribuindo para o fortalecimento da ESF e do SUS.

\section{$1.5 \mathrm{O}$ objetivo da pesquisa}

As considerações apresentadas na introdução deste estudo a respeito do trabalho em equipe e a inserção da Saúde Bucal na Estratégia de Saúde Família permitem delimitar seu objeto de pesquisa, isto é, a produção de cuidados de Saúde Bucal por uma Equipe de Saúde da Família. Movido por esse querer, o de acompanhar o processo de trabalho de uma equipe de saúde, como um território de produção de saberes, práticas, subjetivações e subjetividades, o objetivo desta investigação é cartografar a experiência de uma Equipe de Saúde da Família com relação às possibilidades da construção de um campo de conhecimento e responsabilidade para a práxis de Saúde Bucal. 


\section{CONCEITOS FUNDAMENTAIS DO ESTUDO: PREPARANDO O CAMINHO}

Como o problema desta pesquisa trata da inserção da prática da Saúde Bucal na ESF, esta busca suas fundamentações nos conceitos de trabalho em equipe, na perspectiva da Saúde Bucal na Estratégia Saúde da Família e na Atenção Primária à Saúde/Atenção Básica em Saúde. Iniciaremos discorrendo sobre o tema mais amplo, que se volta à Atenção Primária à Saúde/Atenção Básica em Saúde, passando pela articulação com a Saúde Bucal na Estratégia Saúde da Família e o mais específico para a construção do objeto de pesquisa: o trabalho em equipe.

\subsection{Atenção Primária à Saúde/Atenção Básica em Saúde ${ }^{4}$}

A Organização Mundial de Saúde motivou vários fóruns que contribuíram decisivamente para a formação de um pensamento a respeito da Atenção Primária à Saúde (APS). Em função do reconhecimento às crescentes iniquidades sociais e de saúde presentes em quase todos os países, adotou-se uma série de princípios para construir a base da atenção primária dos serviços de saúde para os países da Comunidade Europeia, incluindo-se a publicação da Carta de Lubliana, em 1996 (MENDES, 2002; STARFIELD, 2004).

Esses princípios referem-se à organização dos sistemas de saúde, de forma que sejam dirigidos por valores de dignidade humana, equidade, solidariedade e ética profissional; direcionados para a proteção e promoção da saúde; centrados na pessoa; focados na qualidade; baseados em financiamento sustentável para permitir a cobertura universal e acesso equitativo e direcionados para a atenção primária (THE LJUBLJANA..., 1996).

Starfield (2004), que tem se destacado na conceituação da APS, define-a por meio dos seus atributos:

1. Atenção ao primeiro contato. As unidades que realizam APS devem ser a porta de entrada do sistema para todas as necessidades e problemas pelo quais as pessoas buscam

\footnotetext{
${ }^{4}$ Neste estudo, estamos tomando os termos Atenção Básica em Saúde (terminologia mais comumente utilizada no Brasil) e Atenção Primária à Saúde como sinônimos.
} 
atenção à saúde, acessível geográfica e socialmente, e com reconhecimento pela população da unidade de saúde como provedora de cuidados e de atenção à saúde.

2. Longitudinalidade. A unidade de APS, a partir do reconhecimento da área de sua competência, da identificação da população eletiva e dos sujeitos dessa área, deve manter uma fonte regular de atenção e de uso ao longo do tempo. Deve haver interação entre o profissional de saúde e os pacientes, na forma da cooperação mútua.

3. Integralidade. A unidade de APS, ao considerar que a atenção deve ser direcionada à pessoa e não à enfermidade, propõe-se a reconhecer os problemas de saúde mais frequentes e organizar-se de forma a lhes oferecer atenção, seja na própria unidade ou em outros serviços.

4. Coordenação. Trata da continuidade da atenção à saúde, seja pelos profissionais ou por meio dos registros de informações dos atendimentos e pelo reconhecimento adequado dos problemas no decorrer do tempo.

5. Foco na família. Considera a família como sujeito da atenção, o que exige uma interação da equipe de saúde com essa unidade social e o conhecimento integral de seus problemas de saúde.

6. Orientação Comunitária. Voltada ao reconhecimento das necessidades familiares segundo o contexto físico, econômico, social e cultural em que vivem, o que exige uma análise situacional das necessidades de saúde das famílias.

Gil (2006), estudando as diferentes compreensões acerca da concepção da APS e da Atenção Básica à Saúde (ABS), verificou que as interpretações para APS são ambíguas, o que é explicado pela trajetória histórica de como esse conceito foi gerado nos fóruns internacionais. Essas variações têm um espectro que se volta: (1) para APS como estratégia de reordenamento do setor saúde; (2) para APS como estratégia de organização do primeiro nível de atenção do sistema de saúde e (3) para APS como programa com objetivos restritos e voltados especificamente à satisfação de algumas necessidades mínimas de grupos populacionais em situação de extrema pobreza e marginalidade.

Esses aspectos são trazidos igualmente em documentos oficiais de organismos internacionais. A Organização Pan-americana de Saúde (2007) discute que a renovação da APS deve ser parte integral do desenvolvimento dos sistemas de saúde, apontando a necessidade de se estabelecer um marco conceitual sustentado por valores, princípios e características essenciais de um sistema de saúde.

Os valores oferecem uma base moral para as políticas e programas. Nesse âmbito, são observados três pontos: direito, ao nível de saúde mais elevado possível, focando-se na questão da 
universalidade e do direito à saúde; equidade, ou a ausência de diferenças injustas no estado de saúde, no acesso à atenção à saúde e aos ambientes saudáveis, que traz imediatamente a concepção de justiça social; e solidariedade, que se refere ao esforço conjunto da sociedade para se conseguir o bem comum. Este aspecto pode ser igualmente pensado nas relações que se estabelecem nos distintos níveis de ação governamental (OPAS, 2007).

Os princípios servem de ponte entre os valores e os elementos estruturais e funcionais do sistema de saúde: dar respostas às necessidades de saúde da população; oferecer orientação para qualidade, sendo, para isso, necessário dotar os trabalhadores de conhecimentos clínicos, epidemiológicos e sociais adequados para a resposta mais oportuna aos problemas e às necessidades identificadas; exigir responsabilidade e prestação de contas dos governos; desejar justiça social; alcançar sustentabilidade, que se volta para o planejamento e compromisso a longo prazo; obter participação, considerando o papel da população no processo de tomada de decisão; e atingir intersetorialidade (OPAS, 2007).

As características essenciais da APS são os elementos estruturais e funcionais do sistema de saúde que viabilizam os seus valores e princípios: acesso e cobertura universal; primeiro contato; atenção integral, integrada e contínua, o que requer a construção de rede de atenção que possa atender aos problemas e às necessidades das pessoas; orientação familiar e comunitária, que indica que o sistema não se foca exclusivamente na perspectiva individual ou clínica e, nesse sentido, toma os pressupostos da Saúde Pública e, como elemento fundamental, a família e a comunidade; ênfase na promoção e na prevenção; atenção apropriada, que sustenta que foco da atenção deve centrar-se na pessoa e não na doença, exclusivamente; mecanismos de participação ativa; marcos político, legal e institucional sólidos; políticas e programas próequidade; organização e gestão otimizadas; recursos humanos apropriados; recursos adequados e sustentáveis, e ações intersetoriais (OPAS, 2007).

Esse conjunto de aspectos vem influenciando a definição de políticas de saúde pelo mundo. O Brasil não foge à regra; pode-se verificar que o Ministério da Saúde (BRASIL, 2007, p.12), ao apresentar, em 2006, a Política Nacional de Atenção Básica, define ABS da seguinte forma:

[...] Atenção básica é um conjunto de ações de saúde que englobam a promoção, prevenção, diagnóstico, prestação do cuidado (tratamento e reabilitação) desenvolvidas através do exercício de práticas gerenciais e sanitárias democráticas e participativas, pautadas numa abordagem transdisciplinar, sob a forma de trabalho em equipe, dirigidas a populações de territórios (território-processo) bem delimitados, das quais assumem responsabilidade, utilizando tecnologias de elevada complexidade e baixa densidade, que devem resolver a maioria dos problemas de saúde das populações (de maior frequência e relevância), sendo seu contato preferencial com o sistema de saúde orientado pelos princípios da universalidade, acessibilidade, continuidade, integralidade, responsabilização, humanização, vínculo, equidade e participação social. 
Em adição, as mudanças ocorridas nas últimas décadas nos padrões de morte e morbidade associadas a transformações demográficas, traduzindo-se por um envelhecimento da população, têm determinado uma mudança no perfil das doenças mais frequentes na população, em quem as doenças transmissíveis são substituídas por doenças não transmissíveis e causas externas. No Brasil, assim como em outros países em desenvolvimento, há uma dupla carga das doenças, em função da transição epidemiológica e demográfica, levando os Sistemas de Saúde a conviverem com as necessidades de organizar seus serviços, em função da ocorrência de doenças agudas e crônicas. A organização de Sistemas de Saúde baseados nos princípios da Atenção Básica à Saúde tem sido indicado como alternativa para o enfrentamento dessa realidade(OPAS, 2005,2007).

\subsection{Saúde Bucal na Estratégia Saúde da Família}

A partir da definição da Política Nacional de Atenção Básica, a Saúde da Família é tomada como estratégia estruturante do sistema de saúde, visando à reorganização da atenção básica no país. Portanto, é importante localizá-la em sua trajetória e retomar a questão da Saúde Bucal nesse processo.

O Programa de Agentes Comunitários (PACS) e o Programa Saúde da Família (PSF), na década de 1990, ganham destaque como estratégias de mudanças do modelo hegemônico de atenção básica em saúde, respaldadas pela forte ideia de direito público à saúde, garantido pelo sistema de saúde brasileiro, o SUS, pelas Leis Orgânicas 8080 e 8142 e, mais recentemente, pela Portaria $\mathrm{n}^{\mathrm{o}}$ 2.488, de 21 de outubro de 2011 (BRASIL, 2011), que definem as diretrizes e os princípios do sistema. Dentre eles está o acesso universal à saúde como um direito público a ser garantido pelo Estado, que faz parte do imaginário coletivo e tem grande adesão dos organismos gestores do sistema de saúde, organizações não governamentais, sindicais e do movimento popular (FRANCO; MERHY, 2003).

O Ministério da Saúde, reconhecendo que, na verdade, o PSF constitui-se em uma estratégia para reorganização do sistema de saúde, passa a denominá-lo, no contexto da definição da Política Nacional de Atenção Básica (BRASIL, 2007), no ano de 2006, de Estratégia Saúde da Família (ESF), denominação que será utilizada nesta pesquisa.

A ESF propõe que se promovam mudanças no modelo vigente de assistência à saúde centrada no médico, essencialmente curativa e com custo incompatível com a universalização 
da atenção à saúde e com o financiamento pelo Estado (BRASIL, 1994). A ESF também tem os objetivos de avançar na implantação do SUS, por meio do fortalecimento dos seus princípios doutrinários e organizacionais, e reorganizar a ABS, por meio das práticas da vigilância da saúde.

O fato de a ESF ser centrada no núcleo familiar possibilita ampliar o conhecimento a respeito do modo de viver dos indivíduos, famílias e comunidade, tornando a compreensão e atenção do processo saúde-doença mais efetivas. Além disso, prioriza as ações de promoção à saúde, as abordagens coletivas, sem descuidar-se das atividades clínicas na busca pela integralidade das ações. Como já trazido, muitos dos aspectos apontados enquanto valores, princípios e organização estrutural e funcional da APS, considerando a ESF, são reafirmados no documento recente da Organização Pan-Americana de Saúde (OPAS, 2007), a Renovação da Atenção Primária à Saúde nas Américas.

Do ponto de vista de sua organização, a Equipe de Saúde da Família é responsável por uma área de referência, com 800 a 1.000 famílias, em média 3.000 indivíduos e composta, no mínimo, por médico, enfermeiro, auxiliar ou técnico de enfermagem e agentes comunitários de saúde (BRASIL, 2007). Esses aspectos conceituais e operacionais que sistematizam certa forma de compreender a ESF, como uma proposição que conforma a ABS no país, têm se firmado como uma opção técnico-política para a ação em saúde no país, reconhecida internacionalmente.

Assim, podemos dizer que a Equipe de Saúde da Família pode ser considerada uma instituição, cujo significado corrente corresponde ao encontrado no dicionário Aurélio (FERREIRA, 2010) e que se refere ao ato de instituir, o de estabelecimento, da coisa instituída ou estabelecida. Para a sociologia, segundo Barbier (1985), instituição é o estudo objetivo das relações que surgem e se reproduzem, com base na coexistência de diferentes pessoas ou grupos em uma sociedade. Fornece um significado, localizando-a tanto no nível geral, das organizações e dos estabelecimentos, como no nível pessoal, mais precisamente, de um simbolismo, quase sempre inconsciente e bastante impositivo, presente em filigranas e sem descontinuidade do macrossocial ao microssocial.

Segundo Barbier (1985), a instituição é uma célula simbólica que contribui para as trocas sociais com fins de reprodução, por meio da sua dimensão universalista, imaginária e instituída, e de produção, pela sua dimensão particular, real e instituinte e que nega o equilíbrio do instituído. A tensão dinâmica entre produção e reprodução sociais, de dimensão singular, simbólica e de institucionalização, realiza o estado de totalização parcial e de 
autorregulação conflituosa, sempre inacabado, da dialética instituinte/instituído. Ainda, esse mesmo autor caracteriza instituição como uma célula simbólica dialetizada, matriz essencial do sistema habitus das pessoas e dos grupos sociais de determinada sociedade e detentora de uma dinâmica dialética instituída e instituinte.

Célula é uma analogia à unidade fundamental dos seres vivos, a célula biológica, estrutura necessária e suficiente para o aparecimento de todas as funções vitais, o que expressa o caráter vivo e dinâmico do sistema social. Assim, a célula precisa manter trocas com o seu meio para sobreviver e se desenvolver, defender-se e adaptar-se a diversos tipos de agressão; é regulada pela temporalidade, nascimento ou criação, desenvolvimento e morte.

As Equipes de Saúde da Família são formadas por profissionais de saúde, cujo objetivo é dar respostas a problemas de saúde de uma determinada área geográfica. Esse conjunto de profissionais, mais ou menos articulados, vão desenvolver uma forma de produzir o cuidado de saúde para sua população adstrita, a qual se modifica durante o tempo, em função das demandas de saúde geradas pelas famílias e membros dessa área. Há outras solicitações externas à equipe, que geram demandas, levando a uma mobilização dos profissionais e, por vezes, da comunidade, a exemplo da Campanha de Combate à Dengue. Por outro lado, ao considerarmos que é considerado substitutivo, portanto, instituinte, o projeto da ESF causará reações de profissionais de saúde e usuários do serviço que se identificam com o modelo tradicional de assistência à saúde, ou seja, do modelo instituído.

O outro aspecto considerado, o simbólico, diz respeito ao conjunto de sistemas simbólicos presentes em todas as culturas, tais como a linguagem, as regras matrimoniais, as relações econômicas, a arte, a ciência e a religião. Os sistemas simbólicos expressam certos aspectos das realidades físicas e sociais e, principalmente, as relações que esses dois tipos de realidade mantêm entre si, assim como a relação entre os sistemas (BARBIER, 1985).

Assim, a Equipe de Saúde da Família, cujo objetivo também é prover cuidado de saúde à família, traz para o seu processo de trabalho um simbolismo relacionado à instituição família, seja de natureza moral, ética, ou voltada às relações sociais.

O Ministério da Saúde insere as Equipes de Saúde Bucal nas Equipes da ESF, com a finalidade de ampliar a atenção à Saúde Bucal da população brasileira, o que pode implicar a conformação de duas instituições, as Equipes de Saúde da Família e os Serviços de Saúde Bucal. Essa inserção é realizada por meio das Portarias Ministeriais n 1444 (BRASIL, 2000) e $n^{\circ} 267$ (BRASIL, 2001), que criaram incentivo financeiro e diretrizes para a reorganização da atenção à Saúde Bucal prestada nos municípios por meio da inserção de equipes de Saúde 
Bucal na ESF, e estabelece duas formas para que esse processo ocorra: uma, com equipe formada por um CD e um Auxiliar de Saúde Bucal (ASB) e outra, composta por um CD, um ASB e um Técnico de Saúde Bucal (TSB). Essa última equipe recebe maior incentivo financeiro.

Consequentemente, insere-se uma célula simbólica, a Saúde Bucal, que historicamente apresenta-se de forma independente de outros serviços nas unidades de saúde, com relação à organização de ações de saúde para uma mesma população, e está centrada na assistência individual e curativa. Trata-se de uma célula simbólica que está em fase de consolidação, mas que tem como um dos seus principais eixos a atenção básica de saúde, o trabalho em equipe de forma interdisciplinar, com foco na família e na promoção da saúde.

A odontologia, segundo Narvai (1994, 2006), iniciou a sistematização de suas práticas em saúde pública a partir da década de 1950, por meio da introdução de métodos e técnicas de planejamento e de programação em saúde. Gradativamente, ampliou-se e fortaleceu-se, de forma mais intensa, após a criação do SUS e elaborou e implantou vários modelos de atenção à Saúde Bucal nessa trajetória. Esses modelos foram formulados em momentos distintos e cada um deles guardou relação direta com o modelo de saúde hegemônico e o momento histórico, construídos a partir do núcleo de competência da odontologia.

O movimento da Saúde Bucal Coletiva, que tem forte influência da Saúde Coletiva e cria uma ruptura com o modelo de odontologia Integral, traz elementos importantes para a construção da prática de Saúde Bucal na ESF: a prática coletiva; a promoção da saúde; a hierarquização em níveis de atenção; a universalização das ações básicas; a adequação tecnológica com a realidade social e cultural, autossuficiente e confiável; o trabalho centrado na equipe de Saúde Bucal; participação comunitária na construção da atenção. Esse movimento tem o propósito de romper com o assistencialismo odontológico e, ao mesmo tempo, construir uma referência teórica para as ações de Saúde Bucal (NARVAI, 1994, 2006).

Como já foi anteriormente observado, Botazzo (1989) afirma que a Saúde Bucal situase num campo extraclínica e engloba práticas de saúde e de outros setores sociais, compondo um campo ampliado de ação a que poderíamos chamar de Saúde Bucal Coletiva e que permite vislumbrar as possibilidades de interação com outras áreas da saúde, com o objetivo de se construir o trabalho em equipe.

Essa ampliação das ações do CD, voltada para a integralidade da atenção em saúde, foi contemplada pelo Ministério da Saúde, por meio das Diretrizes da Política Nacional de Saúde 
Bucal (BRASIL, 2004), da Portaria 648 (BRASIL, 2007) e da Portaria 2488 (BRASIL, 2011), que estabelecem, dentre as atribuições do cirurgião-dentista na equipe da ESF:

[...] III - realizar a atenção integral em Saúde Bucal (promoção e proteção da saúde, prevenção de agravos, diagnóstico, tratamento, acompanhamento, reabilitação e manutenção da saúde) individual e coletiva a todas as famílias, a indivíduos e a grupos específicos, de acordo com planejamento local, com resolubilidade;

[...] VI - acompanhar, apoiar e desenvolver atividades referentes à Saúde Bucal com os demais membros da equipe, buscando aproximar e integrar ações de saúde de forma multidisciplinar.

Capistrano (1999), analisando o desenvolvimento da Saúde da Família no município de São Paulo - Projeto Qualis, destaca a inserção da Saúde Bucal na ESF, como forma de proporcionar uma atenção à saúde integralizada e de melhor qualidade. Outros autores (ALBUQUERQUE, ABEGG, RODRIGUES, 2004; BALDANI et al., 2005; CAVALCANTE et al., 2006; MATOS, TOMITA, 2004; OLIVEIRA, SALIBA, 2005; SANTOS, ASSIS, 2006; SANTOS et al., 2007) também refletiram sobre a inserção da Saúde Bucal na ESF, destacando os seus potenciais com relação ao fortalecimento da atenção primária à saúde e do SUS.

Um dos aspectos a ser considerado nesse processo refere-se à constituição da equipe de trabalho na ESF. A organização do trabalho em equipe passa pela definição de objetivos comuns a todos os profissionais envolvidos que, no caso, são as atribuições de todos os membros da equipe de Saúde da Família. Em um sentido mais amplo, o trabalho em equipe cuida da saúde das famílias de uma área adstrita, de forma cooperativa, convergindo seus objetivos para uma dada situação, de forma a haver integração de saberes e articulação de ações e não soma ou superposição.

Operar de forma cooperativa não implica trabalhar sem conflitos, pois eles são importantes para o processo de formação do grupo; portanto, são inevitáveis e universais. O trabalho cooperativo também não constitui um grupo primário, ligado pelo afeto, e sim se configura como um grupo secundário, que se liga por papéis e funções (CAMPOS, 2000).

Um conjunto de profissionais trabalhando sob um mesmo teto, com horários previstos para discussão e encaminhamento de casos de família, configura um processo de trabalho multidisciplinar, que pode ser caracterizado pela simples justaposição, num trabalho determinado, dos recursos de várias disciplinas, descartando um trabalho de equipe, cooperativo e coordenado. No trabalho multidisciplinar, a solução de um problema só exige informações tomadas de empréstimo a duas ou mais especialidades ou setores de conhecimento, sem que as disciplinas levadas a contribuírem para aquela que as utiliza sejam 
modificadas ou enriquecidas. Portanto, consiste em agrupamento de módulos disciplinares, sem relação entre elas (JAPIASSU, 1976). Assim, a colaboração é pautada pelo monólogo de cada especialista envolvido no processo, não havendo integração conceitual ou metodológica.

De outra forma, a interdisciplinaridade está fundamentada no campo unitário do conhecimento, em que a colaboração entre diversas disciplinas ou entre os setores heterogêneos de uma mesma ciência conduz a interações propriamente ditas; isto é, há certa reciprocidade nos intercâmbios, de tal forma que, no final do processo interativo, cada disciplina sai enriquecida e é transformada. A interdisciplinaridade caracteriza-se pela intensidade das trocas entre os especialistas e pelo grau de integração real das disciplinas, no interior de um projeto específico de pesquisa (JUPIASSU, 1976).

Podemos dizer que o processo de colaboração interdisciplinar ocorre todas as vezes em que nos reconhecermos diante de um empreendimento interdisciplinar, em que ele conseguir incorporar os resultados de várias especialidades, ao tomar de empréstimo de outras disciplinas certos instrumentos e técnicas metodológicas, fazendo uso dos esquemas conceituais e das análises que se encontram nos diversos ramos do saber, a fim de fazê-los integrarem e convergirem, depois de terem sido comparados e julgados (JUPIASSU, 1976).

Por último, cabe considerar o cuidado em saúde, que, segundo Boff (2003), significa solicitude, zelo, atenção e bom trato para com o outro. É um modo de ser, em que as atitudes passam a ser centradas no outro, com dedicação e solicitude. A atitude de cuidado pode provocar preocupação, inquietação e sentido de responsabilidade, porque a pessoa que tem cuidado se sente envolvida e afetivamente ligada ao outro.

Boff (2003) descreve duas formas de o homem coexistir e relacionar-se com todas as coisas do mundo: o trabalho e o cuidado. A forma de trabalho configura o situar-se sobre as coisas para dominá-las e colocá-las a serviço dos interesses pessoais e coletivos, exigindo objetividade, que, por sua vez, impõe certo distanciamento da realidade, a fim de estudá-la como a um objeto para acumular experiências e dela assenhorar-se. Continua Boff (2003, p. 94):

[...] cumpre enfatizar que os "objetos" não são objetos em si. São feitos pela razão, pois ela os isola de seu meio, os separa de outros companheiros de existência e os usa para seus interesses. A "objetividade" é uma projeção da razão. Os ditos "Objetos" na verdade, são sujeitos que têm história, acumulam e trocam informações e pertencem à comunidade cósmica e terrenal.

O modo de ser cuidador não se opõe ao do trabalho, mas lhe confere a tonalidade de não vermos nele tudo como objetos, mas sujeito-sujeito. A relação deixa de ser de domínio e passa a ser de convivência e interação. 
Merhy (2002) diz que, no campo da saúde, o objeto a ser trabalhado é a produção do cuidado, por meio do qual se crê que se atinjam a cura e a saúde, que são, de fato, os objetivos a que se quer chegar.

Por outro lado, estar doente significa um dano à totalidade da existência. Não é uma parte do corpo que sofre, mas é a vida que adoece, em suas várias dimensões: em relação a si mesmo, experimentando os limites da vida mortal; em relação à sociedade, ao se isolar, deixar de trabalhar e ter que se tratar em uma unidade de saúde; em relação ao sentido global da vida, descrédito na confiança fundamental da vida, perguntando-se por que exatamente ficou doente. Para a Saúde Bucal, essa constatação corresponde ao fato de as pessoas sentirem-se constrangidas, ou mesmo impedidas, à convivência social diante de um problema de Saúde Bucal, que, a princípio, não é causa de mortalidade, mas as impede de mastigar os alimentos ou expressar emoções.

\subsection{Trabalho em Equipe - elemento estruturante para o campo de competência e responsabilidade?}

Como apontado anteriormente, a questão do trabalho em equipe é um dos conceitos estruturantes da presente investigação. Utilizaremos a tipologia de Peduzzi (2001) para sustentar a reflexão aqui proposta, considerando-se os elementos que a autora aponta para a construção da equipe de integração. O primeiro elemento considerado é a comunicação entre os agentes do trabalho, que trata do uso da mediação simbólica da linguagem para articular as ações, a coordenação, a integração dos saberes e a interação dos agentes; ou seja, a comunicação entre os profissionais é o denominador comum do trabalho em equipe, o qual decorre da relação recíproca entre trabalho e interação.

Essa comunicação pode dar-se de três diferentes formas. Na primeira, a comunicação aparece externa ao trabalho. Desse modo, ela não é realizada; quando muito, é exercida apenas como instrumentalização da técnica, como recurso para sua otimização. Os agentes experimentam tensão entre o comunicativo e o instrumental, sem um agir comunicativo. $\mathrm{Na}$ segunda, a comunicação ocorre em caráter pessoal, em que os agentes dão destaque à dimensão das relações pessoais, baseadas no sentimento de amizade e camaradagem e operam em uma sobreposição das dimensões pessoal e tecnológica. Assim, conhecer o profissional equivale a conhecer como é executado seu trabalho e o saber técnico que o fundamenta. Essa sobreposição 
leva a uma redução da interação, com o que se reduz a noção de trabalho em equipe na mesma direção: a das boas relações interpessoais. Mesmo havendo certa comunicação, não ocorre o agir comunicativo. A terceira diz respeito a uma comunicação que é praticada como dimensão intrínseca ao trabalho em equipe. Os agentes destacam, como característica do trabalho em equipe, a elaboração de linguagens comuns, objetivos comuns, propostas comuns, ou mesmo cultura comum. Buscam a elaboração de um projeto assistencial comum, construído por meio da intricada relação entre execução de intervenções técnicas e comunicação dos profissionais (PEDUZZI, 2001).

Peduzzi (2001) afirma que essa situação trata da perspectiva do agir comunicativo no interior da técnica, o que, dada a hegemonia instrumental do agir técnico, também acaba por gerar tensões. Enquanto o agir técnico, ou agir instrumental, busca um dado fim a priori, independente do percurso, o agir comunicativo é uma situação em que as mediações são o próprio fim, ou seja, a finalidade é interagir e, nesse processo, construir consensos pertinentes a cada contexto.

O segundo critério para reconhecer o tipo de trabalho em equipe é o reconhecimento da construção pela equipe de um dispositivo que funciona como sinalizador de sua integração, um eixo em torno do qual se dá a dinâmica cotidiana de trabalho e de interação, caracterizados pelo projeto assistencial comum. Esse projeto comum trata de um plano de ação para uma situação concreta de trabalho coletivo em equipe e é específica para cada equipe e não conforma uma prescrição de funcionamento para outras equipes. Os agentes partem de uma determinada realidade e constroem, pelo trabalho e pelo agir comunicativo, um projeto pertinente às necessidades de saúde, tal como percebida pelos usuários e profissionais. Neste processo, a equipe leva em consideração o projeto assistencial hegemônico, que não pode ser ignorado, por ser o modelo dominante de atenção à saúde, mas reelabora-se, gerando um novo projeto comum, dentro de certo campo de possibilidades(PEDUZZI, 2001).

$\mathrm{O}$ terceiro critério refere-se à divisão do trabalho em saúde e parte-se do reconhecimento da prática médica como fundadora da técnica científica moderna na área da saúde e, portanto, núcleo original do qual derivam os outros trabalhos especializados. Os trabalhos que se separam ou se agregam ao trabalho do médico compõem um conjunto diversificado de áreas profissionais, necessárias à implementação da totalidade das ações que podem viabilizar a atenção integral à saúde. Configuram-se em trabalhos tecnicamente diferentes, mas também desiguais quanto à valorização social (PEDUZZI, 2001). 
Peduzzi (2001) observou que, no trabalho coletivo em que há menor desigualdade entre os diferentes trabalhos e os respectivos agentes, há uma maior integração na equipe. $\mathrm{Na}$ medida em que o trabalho em equipe é construído, efetivamente, na relação intrínseca entre trabalho e interação, maiores são as possibilidades de interagirem em situações livres de coação e de submissão, na busca de consensos acerca da finalidade e do modo de executar o trabalho.

O quarto critério trata das especificidades dos trabalhos especializados e da flexibilidade da divisão do trabalho. As diferenças técnicas que caracterizam as especificidades do trabalho de cada área da saúde expressam a possibilidade de contribuição da divisão do trabalho para a melhoria dos serviços prestados, uma vez que a especialidade permite aprimoramento do conhecimento e do desempenho técnico em determinada área de atuação, bem como maior produção. Os profissionais de saúde destacam a necessidade de preservar as especificidades de cada trabalho especializado, o que implica manter as diferenças técnicas correlatas e, por outro lado, expressam a necessidade de flexibilizar a divisão do trabalho, para que haja coexistência de ações privativas das respectivas áreas profissionais e ações que são executadas, indistintamente, por agentes de diferentes campos de atuação. Ou seja, os profissionais realizam intervenções próprias de suas respectivas áreas profissionais, mas também executam ações comuns, nas quais estão integrados saberes provenientes de distintos campos, tais como recepção, acolhimento, grupos educativos, grupos operativos e outros. No seu estudo, Peduzzi (2001) observou que quanto maior for a ênfase na flexibilidade da divisão do trabalho, maior proximidade se terá da equipe-integração e, quanto maior a ênfase na especificidade dos trabalhos, mais próximo se estará da equipe agrupamento.

O último critério é o da autonomia técnica. Peduzzi (2001) aponta, em seu estudo, três concepções distintas: 1) o profissional trabalha com autonomia plena, buscando alcançar o mais amplo espectro de independência na execução de suas intervenções; 2) o profissional ignora o âmbito de autonomia no qual realiza seu trabalho, e 3) o profissional apreende o caráter interdependente em relação ao julgamento e à tomada de decisão de outro agente, dada a complementaridade dos trabalhos especializados.

A autora observou que, no trabalho em equipe do tipo integração, há complementaridade e colaboração no exercício da autonomia técnica e não há independência dos projetos de ação de cada agente. Com relação ao tipo agrupamento, a complementaridade objetiva que os trabalhos especializados convivem com a independência do projeto assistencial de cada área 
profissional ou mesmo de cada agente, expressando a concepção de autonomia técnica plena dos agentes.

Esse conjunto de conceitos, separados nos tópicos enunciados acima, na tentativa de esclarecê-los, estão articulados e sustentam o caminho empreendido nesta investigação, permitindo lançar um olhar comprometido com as nuances aqui apontadas, para a realidade da USF Rubi e de sua equipe, no desenvolvimento do trabalho na ABS. 


\section{CARTOGRAFANDO A SAÚDE BUCAL NA SAÚDE DA FAMÍLIA}

Esta investigação insere-se no campo da Saúde Coletiva, a qual, nas últimas cinco décadas, tem se constituído em um campo em construção de teorias e práticas em saúde e é caracterizada pela produção de um conhecimento interdisciplinar das áreas da saúde e das ciências sociais, passando a ter, no social, uma categoria analítica básica para a compreensão do processo saúde-doença-cuidado (FELIPE, 1989).

Dentre os conteúdos temáticos desenvolvidos no campo da Saúde Coletiva, têm-se identificado estudos referentes à política de saúde; à organização de programas e serviços de saúde; à interdisciplinaridade no trabalho, na educação, no ambiente e na saúde; à Saúde Bucal; às representações sociais; aos estudos sobre subjetividades e aos fatores psicossociais (NUNES, 2010).

O campo da Saúde Coletiva tem a sua especialidade no seu objeto, o coletivo, o qual the atribui sentidos de meio, de conjunto, de indivíduo, de interação entre elementos, de conjunto de efeitos ou consequências da vida social e, finalmente, de coletivo transformado em social, como campo específico de práticas (CANESQUI, 1995). O objeto da Saúde Coletiva não é representado estritamente por corpos biológicos, mas por corpos sociais. Em outras palavras, não se trata de lidar com meros indivíduos, mas com sujeitos sociais, grupos e classes sociais e relações sociais referidas ao processo saúde-doença (FELIPE, 1989).

A abordagem adotada, em vista da natureza do objeto de pesquisa, é a Pesquisa-intervenção (PASSOS; KASTRUP; ESCÓSSIA, 2009), cujo método é a cartografia (DELEUZE; GUATTARI, 2009) uma vez que este estudo analisa as possibilidades da construção de um campo de saberes e práticas de Saúde Bucal por uma Equipe de Saúde da Família, com a possibilidade de, em processo, transformar a realidade social e epidemiológica encontrada. Ainda é importante apontar que a opção pela pesquisa- intervenção e pela cartografia tem, como sustentação, os conceitos apresentados de APS/AB, Saúde Bucal na Saúde da Família e trabalho em equipe, mediados pelo arcabouço teórico do movimento institucionalista.

\subsection{Fazendo aproximação com a cartografia}

No processo de construção do objeto de estudo e da metodologia, partimos da compreensão de que se tratava da inclusão da prática de Saúde Bucal em uma equipe de trabalhadores de saúde. Dentre as modalidades de pesquisa participante, a pesquisa-ação poderia ser uma alternativa em razão das possibilidades de produção de conhecimento em 
torno da articulação entre teoria e prática, sujeito e objeto, entre a ação desenvolvida por um grupo e o conhecimento que dela se depreende.

Entretanto, a ausência de evidências científicas, no campo da Saúde Bucal, que pudessem oferecer maior consistência e coerência à opção da metodologia da pesquisa-ação, tornou-se necessário procurar outras alternativas de pesquisa participante. Em função disso, verificou-se que a pesquisa-intervenção apresentava maior possibilidade de articulação e coerência com a abordagem da análise institucional. Ou seja, a pesquisa-intervenção apresenta consistência e coerência metodológicas e maior possibilidade de compreensão da articulação teoria/prática e objeto/sujeito.

A cartografia é o método da pesquisa-intervenção que se presta a acompanhar processos, diferente do sentido dado pelos referenciais positivistas ao método, que tem a intenção de acompanhar para alcançar metas prefixadas (méta-hódos). A cartografia é uma reversão (hódos-méta), propõe-se a um caminhar que traça, no percurso, suas metas, sempre considerando os efeitos do processo do pesquisador sobre o objeto da pesquisa, o pesquisador e seus resultados (PASSOS; KASTRUP; ESCÓSSIA, 2009), movimento trilhado na presente investigação, em que, a cada passo, foram se revendo os resultados e as possibilidades junto à Equipe de Saúde da Família.

O método da cartografia foi descrito por Deleuze e Guattari (2009), no livro Mil Platôs, no qual os autores apresentam um sistema que busca contemplar a multiplicidade da realidade, a partir de uma crítica à percepção do mundo, baseada em um sistema binário, com uma lógica dicotômica. Deleuze e Guattari (2009) fazem uma analogia às características estruturais do sistema radicular ou fascicular, concebida pela Botânica, utilizando o sistema binário e o rizoma para abordar a multiplicidade da realidade.

Deleuze e Guattari (2009) recorrem a seis características para facilitar a compreensão do rizoma. Duas delas referem-se à cartografia e decalcomania. A decalcomania está relacionada à lógica binária, a um modelo estrutural ou gerativo, baseada na ideia de eixo genético ou de estrutura profunda, uma unidade pivotante e objetiva, sobre a qual se organizam estados sucessivos, em uma estrutura profunda. Deleuze e Guattari (2009, p. 22), dizem que a decalcomania

[...] tem como finalidade a descrição de um estado de fato, o reequilíbrio de correlações intersubjetivas, ou exploração de um inconsciente já dado, nos recantos obscuros da memória e da linguagem. Ela consiste em decalcar algo que se dá já feito, a partir de uma estrutura que sobre codificada ou de um eixo que suporta. A árvore articula e hierarquiza os decalques, os decalques são como folhas de árvores. Diferente é o rizoma, mapa e não decalque. 
O mapa está inteiramente voltado para uma experimentação ancorada no real e não reproduz um inconsciente fechado sobre ele mesmo; ele o constrói e contribui para a conexão de campos. Um mapa deve ser produzido, construído, sempre desmontável, reversível, suscetível de receber modificações constantemente, com múltiplas entradas e saídas, com suas linhas de fugas.

Passos, Kastrup e Escóssia (2009) continuam dizendo que cartografar é uma Pesquisaintervenção, em que o conhecer e o fazer se tornam inseparáveis, dados por uma prática do conhecer que se refere ao fazer e ao criar uma realidade de si e do mundo, sem a pretensão da neutralidade ou suposição de sujeito e de um objeto implicacional, conhecido previamente segundo a relação que os liga.

Deleuze e Guattari (2009) continuam compondo a cartografia, dizendo que um rizoma é feito de platôs, os quais podem ser definidos como uma região contínua de intensidades, vibrando sobre ela mesma, e que se desenvolve, evitando toda orientação sobre um ponto culminante ou em direção a uma finalidade. Também é toda multiplicidade conectável com outras hastes subterrâneas superficiais, de maneira a formar e estender em rizoma. Um rizoma conecta um ponto qualquer com outro ponto e cada um de seus traços não remete necessariamente a traços da mesma natureza.

O CD ou a Equipe de Saúde Bucal, tradicionalmente, desenvolve suas atividades de forma isolada do restante dos profissionais de saúde das unidades de saúde, o que é uma realidade distinta dos médicos e enfermeiros, auxiliares e técnicos de enfermagem, cuja prática profissional acontece no trabalho em equipe nas unidades de saúde e ambientes hospitalares, ainda que majoritariamente de forma fragmentada.

O saber relacionado à prática de um CD compõe um platô que está conectado a outros platôs, compostos por saberes de outras disciplinas, como, a microbiologia, a bioquímica, a engenharia de materiais, a epidemiologia, a estatística e a sociologia. As especialidades odontológicas clínicas irão intensificar algumas das conexões no mesmo platô. A especialidade Saúde Bucal Coletiva, que possui uma especificidade em torno do serviço público de saúde, do SUS, das Ciências Sociais, da Epidemiologia, rompe com a atividade puramente clínica, compondo outro platô, conectado com platôs estabelecidos por cada uma das especificidades da área, de outras disciplinas e, fundamentalmente, da odontologia.

Nas palavras de Passos, Kastrup e Escóssia (2009), Guattari propõe o conceito de transversalidade como aumento dos quanta comunicacionais intra e intergrupos, em uma instituição, para problematizar os limites do setting clínico. Segundo Guattari (2004), o tema da 
transversalidade se desdobra no tema das redes comunicacionais, na análise da dinâmica comunicacional nas instituições, colocando, lado a lado, o que é distinto, tornando grupo-sujeito e grupo sujeitado como dinâmicas que diferem, mas não se separam. O que importa é o que se passa entre os grupos, nos grupos, no que está para além e aquém da forma dos grupos, entre as formas ou no atravessamento delas. A rede conecta termos, dando consistência ao espaço intermediário. Os grupos, as instituições e as organizações são redes de inter-relações, isto é, relações entre relações; portanto, trata-se de acompanhar os processos intermediários, o que Guattari denomina de Método da Cartografia do Intermediário.

Guattari (2004) diz que transversalidade é uma dimensão que pretende superar dois impasses. Um se refere à verticalidade pura, relacionada à hierarquia dos organogramas de uma estrutura piramidal. O outro se refere a uma simples horizontalidade que organiza os iguais de forma cooperativa, levando ao aumento do coeficiente de transversalidade.

Podemos exemplificar essa situação com os momentos que algumas Equipes de Saúde da Família criaram e que são destinados à discussão de casos de família. Nessas reuniões, são apresentadas informações a respeito das condições socioeconômicas, de agravos à saúde e dos riscos para o adoecimento, o que pode gerar ou não a elaboração de projetos terapêuticos. Observando uma dada equipe de Saúde da Família, pudemos verificar que, em alguns momentos, houve um esforço para minimizar a hierarquia de poder presente na equipe e o resultado foi um alto grau de comunicação. Em outros momentos, a soberania médica se fez valer, e o grau de comunicação intragrupo tornou-se baixo.

A ESF é uma estratégia para uma mudança do modelo hegemônico de saúde, caracterizado por um funcionamento centrado no médico e essencialmente focado em ações curativas. Por outro lado, o fato de a odontologia trabalhar de forma isolada e autônoma dos outros profissionais expressa uma fragmentação do corpo e da atenção à saúde, o que poderia ser expresso por meio da caricatura, uma representação em que, para alguns, o corpo não tem boca e, para outros, a boca é um ser ambulante, demonstra haver um baixo coeficiente de transversalidade.

O Ministério da Saúde, ao normatizar as modalidades de inserção de profissionais da área de Saúde Bucal, organizados em equipes, nas Equipes de Saúde da Família, não disponibiliza mecanismos para operar a inserção da boca no corpo e vice-versa e acaba por reproduzir a dicotomia, separando a saúde centrada no corpo da Saúde Bucal.

A inserção da equipe de Saúde Bucal em outra, a de Saúde da Família, no contexto do desenvolvimento de um processo de trabalho interdisciplinar que gera processos grupais, irá 
causar estranhamentos, explicitar diferenças e distanciamento entre as duas equipes e pede reconfigurações de universos referenciais (DELEUZE; GUATTARI, 2009). No cotidiano da equipe pode haver troca de saberes e práticas entre os profissionais, o que pode desencadear nessa arena, a manifestação de subjetividades relacionadas ao objeto da odontologia, o cuidado a boca, o tratamento odontológico, e o despertar de sentimentos com relação a perda de poder, de democratização de saberes e os relacionados às vivências individuais com o cuidado odontológico, ás vezes traumáticas. Uma das formas de tornar possível que a equipe deixe de reproduzir os modelos de assistência odontológica centrados no procedimento cirúrgicorestaurador e passe a repensar o modelo de atenção à Saúde Bucal seria um possível diálogo a respeito dessas questões, para que o dentista possa democratizar o conhecimento da Saúde Bucal de uma forma horizontalizada e submetê-la ao grupo.

\subsection{A opção pela Pesquisa-intervenção (PI)}

A pesquisa-ação (PA), a pesquisa-intervenção (PI) e a pesquisa participante (PP) são métodos que se filiam a um paradigma reconhecido como pesquisa participante. Foram constituídas em diferentes momentos e todas se apresentam como proposta de mudança na produção do conhecimento, sobretudo nas relações entre teoria-prática e sujeito-objeto (ROCHA; AGUIAR, 2003).

Rocha e Aguiar (2003) afirmam que a literatura científica estrangeira preocupa-se em diferenciar as pesquisas participativas das não participativas; já a literatura brasileira destacar diversas tendências metodológicas que envolvem o conceito de participação, que é polêmico e de difícil compreensão. Assim, tornou-se necessário compreender os tipos de pesquisas participantes e suas premissas metodológicas, com a finalidade de identificar qual delas seria a mais adequada para investigar o processo de construção de um campo de conhecimento e de prática relacionado à Saúde Bucal por uma Equipe de Saúde da Família.

Brandão (2001) lembra que a prática atual da PP é recente, embora formas pioneiras tenham sido realizadas, a exemplo do questionário de uma enquete realizada por Karl Marx entre operários, cujo propósito era fazê-los pensar sobre sua condição, enquanto respondiam a um questionário. Seu objetivo não era apenas coletar dados, mas associar a produção de conhecimento à transformação da prática, por meio da conscientização e sensibilização. 
Paulon (2005), ao discutir as distinções entre os tipos de pesquisas participantes, destaca que há avanços proporcionados por essas metodologias, em função de suas críticas às concepções conservadoras que regiam as ciências sociais, as quais dicotomizam teoria e prática e sujeito e objeto, na tentativa de neutralizar a ação do pesquisador. O autor remete-se aos questionamentos a respeito da posição que o pesquisador assume em seu campo de pesquisa, às relações que estabelece com os sujeitos de sua investigação, aos efeitos que essas relações produzem em suas observações e à possibilidade de que a análise dos dados seja enriquecida ou deturpada por tais efeitos. Em síntese, ele se remete ao problema da objetividade versus neutralidade do trabalho de investigação.

Adicionalmente, Oliveira e Oliveira (1985 apud ROCHA; AGUIAR, 2003) localizam os tipos de pesquisas participativas no campo da prática, considerando que são estratégias de pesquisa que têm como proposta a participação de grupos sociais na busca de soluções para os problemas do cotidiano e envolvem um processo de compreensão e mudança da realidade. Continuam dizendo que, para desenvolver uma metodologia participativa, é necessária uma mudança na postura do pesquisador e dos pesquisados, uma vez que todos são coautores do processo de diagnóstico da situação-problema e da construção de vias que possam resolver as questões. É um processo contínuo que acontece no curso da vida cotidiana, transformando os sujeitos e demandando desdobramentos de práticas e relações entre participantes. Rocha e Aguiar (2003) acrescentam que o fundamental nas pesquisas participativas é que o conhecimento produzido esteja permanentemente disponível para todos e possa servir de instrumento para ampliar a qualidade de vida da população.

Thiollent (2001) diz que toda PA é um tipo de PP, mas nem toda PP é PA, uma vez que a PP preocupa-se com o papel do investigador dentro da situação investigada, problematiza a relação do pesquisador/pesquisado para estabelecer a confiança e outras condições favoráveis a uma melhor captação de informações, mas não problematiza a relação entre investigação e ação dentro da situação considerada.

No caso da presente investigação, o pesquisador está inserido na equipe, como trabalhador; portanto, considera-se que as questões de estranhamento relacionadas à inserção de um novo sujeito no ambiente de trabalho já estão de certa forma minimizados, restando um novo status a ser trabalhado, que é de um trabalhador-pesquisador. Nesse sentido, busca-se desde o recorte da investigação, quando da exploração do campo, estabelecer uma "distância ótima" necessária à problematização desta dupla relação "equipe/membro da equipe" “equipe/pesquisador". Não é movimento simples e ausente de conflitos, mas sempre presente, 
de modo a buscar um campo de visão da problemática investigada. Portanto, trata-se de ir além de observar as práticas de Saúde Bucal desenvolvidas pela equipe, sem que haja estranhamento da presença do pesquisador pelos pesquisados, para verificar as possibilidades de mudanças entre teoria e prática e sujeito e objeto, em busca de uma nova Saúde Bucal, construída pela interdisciplinaridade e que pode potencializar suas ações.

É consenso atribuir a Kurt Lewin o desenvolvimento de pesquisas de campo com uma possibilidade distinta de articulação entre teoria e prática, sujeito e objeto nas investigações sociológicas, psicológicas, educacionais e organizacionais (TRIPP, 2005; ROCHA, AGUIAR, 2003). Também é atribuída a Kurt Lewin a criação da Action Research, PA, e a dinâmica de grupo, ambos fundamentados na psicossociologia ativa frente às questões sociais, em que a gênese social precedia a gênese teórico-metodológica. Essa proposta se afirma como instrumento para resolver problemas de ajustamento das populações marginais, trabalhar as crises nas relações de trabalho, aliviar tensões em situações problemáticas. Também teve utilidade para desenvolver as ciências sociais, por meio de ações concretas na realidade (TRIPP, 2005; ROCHA, AGUIAR, 2003; BARBIER, 1985, 2007). Nesse sentido, o método da PA oferece maiores possibilidades de responder às questões entre teoria e prática, que, segundo Thiollent (2001), é um tipo de pesquisa participante centrada no agir.

Segundo Barros (1994 apud ROCHA; AGUIAR, 2003, p.2), Lewin ao propor a PA, desestabiliza o mito da objetividade na produção do conhecimento, destacando que a implicação do pesquisador está presente no processo de investigação e que, por estar incluído no campo, sua ação de pesquisar modifica o objeto estudado.

Rocha e Aguiar (2003) afirmam que, para Lewin, a ordem social é naturalizada e as crises e conflitos são interpretados como desordens, efeitos disfuncionais, cujas resistências à mudança são alvos de intervenção. As análises ocorrem no nível micro-organizacional, com a perspectiva de aperfeiçoar recursos e relações para um funcionamento social adequado. Enquanto a pesquisa tem um caráter utilitário, o pesquisador tem a função de facilitar as relações humanas e mantém cisões, como teoria/prática e sujeito/objeto, definindo uma linha de chegada a priori e modelos a serem atingidos.

Paulon (2005) define a PA como uma modalidade de pesquisa participante, centrada na ação, uma vez que o pesquisador social contribui efetivamente com relação aos problemas de um coletivo pesquisado, ou seja, há uma intenção de dispor de instrumentos teórico-metodológicos em prol dos objetivos existentes no grupo sob o qual sua ação vai ser desenvolvida. $O$ autor continua dizendo que a atitude do pesquisador é direcionada para a elucidação dos diversos 
interesses e aspectos envolvidos na situação, incluindo-se aí, necessariamente, a relação existente entre os objetivos da pesquisa e os objetivos da ação. A PA preocupa-se com a articulação constante entre a ação desenvolvida por um grupo e o conhecimento que dela se depreende.

Entretanto, Paulon (2005), ao diferenciar a PA e a PI para verificar qual é o método mais adequado para a compreensão da teoria/prática e objeto/sujeito, diz que, enquanto o primeiro método fundamenta-se na necessidade de que o agir seja planejado para que os sujeitos da pesquisa modifiquem o objeto de pesquisa, para que suas ferramentas teóricas surtam efeitos sobre o campo prático, o projeto político da PI destina-se ao reequacionamento da relação sujeito-objeto e o redirecionamento da relação teoria/prática.

Passos e Barros (2000) lembram que, em Lewin, a gênese social do objeto da pesquisa precede à gênese teórica e metodológica, enquanto na proposta da PI a gênese teórica e social são indissociáveis. O momento da pesquisa é o momento da produção teórica e, principalmente, da produção do objeto e daquele que conhece; o momento da pesquisa é o momento da intervenção, já que pesquisadores e sujeitos estão implicados no processo de produção de conhecimento. Os autores assinalam, ainda, que há um caráter utilitário na PA em sua versão praxiológica; por outro lado, a PI tem como mote o questionamento do "sentido" da ação.

Outro aspecto importante observado por Passos e Barros (2000) é que a PA tem como objetivo a mudança de comportamento, entendida como a chegada a um determinado resultado previamente definido, enquanto a PI interessa-se pelos movimentos, as metamorfoses, não definidos a partir de um ponto de origem e um alvo a ser atingido, mas como processos de diferenciação. Trata-se de dar um sentido à PA à luz do pensamento do Movimento Institucionalista, não se tratando mais de uma metodologia com justificativas epistemológicas, e sim de um dispositivo de intervenção no qual se afirme o ato político que toda investigação constitui, porque a PI acentua, a todo o tempo, o vínculo entre a gênese teórica e a gênese social dos conceitos, o que é negado implícita ou explicitamente nas versões positivistas tecnológicas de pesquisa (Rodrigues; Souza, 1987, apud ROCHA; AGUIAR, 2003).

A respeito dessa ressignificação, Barbier (1985) conceitua PA como atividade de compreensão e de explicação da práxis dos grupos sociais por eles mesmos, com o objetivo de melhorar essa práxis. O referencial do Movimento Institucional leva a PA a um tipo particular, cujo objeto refere-se ao campo institucional no qual gravita o grupo em questão. Trata-se de desconstruir as redes de significações da qual a instituição é portadora. 
Passos e Barros (2000) ainda fazem consideração a respeito das metodologias que utilizam questionários e entrevistas, técnicas consideradas fidedignas, mas que criam a ilusão de que o pensamento de cada um pode ser "agarrado" na coleta de dados. A expectativa é de objetividade e organização dos problemas. A crença é que se melhor apreende a realidade quanto mais versões se acumulem sobre ela. Tais premissas mantêm, de todo modo, o objeto como algo a ser apreendido; tal apreensão é garantida pela estrutura a priori do fenômeno que se quer conhecer. A PI, como instrumento de aproximação com o campo, mostra-nos que ambos, pesquisador e pesquisado, ou seja, sujeito e objeto do conhecimento, constituem-se no mesmo momento e no mesmo processo.

Outra distinção apontada por Passos e Barros (2000) entre PA e PI é a compreensão da implicação do pesquisador. Kurt Lewin aponta para os aspectos afetivo/libidinais do pesquisador na PA. A noção de implicação na análise institucional não se resume a uma questão de vontade, de decisão consciente do pesquisador, mas inclui uma análise do sistema de lugares, o assinalamento do lugar que ocupa o pesquisador, daquele que ele busca ocupar e do que lhe é designado ocupar, como especialista, com os riscos que isto lhe implica. Trata-se da análise das relações sociais entre observador e observado, que quase sempre estão ocultas.

René Lourau, analista institucional, diz que a implicação é o cerne do trabalho socioanalítico e não consiste em apenas analisar os outros, mas em analisar a si mesmo a todo momento, inclusive no momento da própria intervenção, de forma individual e coletiva, o que é uma atividade intensa e muitas vezes penosa. As implicações podem ser da ordem libidinal, que estão presentes nos grupos e em qualquer situação de vida, e trata-se dos sentimentos afetivos homossexuais ou heterossexuais. Podem ocorrer na forma de jogos de sedução, visando ao exercício de certa hegemonia de poderes e podem ser ideológicos e políticos, que, durante a investigação, podem gerar situações de conflito (ALTOÉ, 2004; RODRIGUES, 1993).

A Análise Institucional Socioanalítica, que influencia a PI, é uma corrente desenvolvida na França, durante as décadas de 1960 e 1970, e tem por objetivo interrogar os diversos sentidos cristalizados nas instituições. A intervenção está associada à construção e/ou utilização de analisadores, que é um conceito-ferramenta elaborado por Felix Guattari. Esses analisadores seriam acontecimentos que causam rupturas, que catalisam fluxos, que produzem análise, que decompõem. Eles assinalam as múltiplas relações que compõem o campo em relação a intervenção e da análise (PASSOS; BARROS, 2000). 
Considerando-se o conjunto desses elementos teóricos acerca das possibilidades entre os tipos de Pesquisas Participantes, a opção que se mostrou mais articulada aos objetivos e à perspectiva colocada para o presente estudo foi a Pesquisa-Intervenção, uma vez que o objetivo desta pesquisa não está restrito aos aspectos da inserção do pesquisador no campo de pesquisa ou à construção de uma prática de Saúde Bucal. Antes, busca-se compreender o processo de construção, por uma equipe de Saúde da Família, de um campo de Saúde Bucal Coletiva, as relações dos profissionais com esse campo, as suas potencialidades e seus limites.

Acompanhar processos é um tributo da cartografia, que é o método da PI, no sentido da processualidade, cujo objetivo é a investigação de processos de produção de subjetividade (PASSOS; KASTRUP; ESCÓSSIA, 2009). Assim, processualmente, ao se constituir a opção mais adequada, também foi se definindo e constituindo como suporte teórico para realização deste estudo a Análise Institucional5 (BAREMBLITT, 2002).

Durante todo o percurso trilhado, trabalhamos com as concepções de provisoriedade do conhecimento produzido e a construção de momentos da pesquisa, que se sucedem sem se separar, como o próprio ato de caminhar, onde um passo segue o outro num movimento contínuo e cada momento da pesquisa traz consigo o anterior e se prolonga nos momentos seguintes (PASSOS; KASTRUP; ESCÓSSIA, 2009). Não se considerou uma forma rígida para a realização da pesquisa, segundo etapas predeterminadas, sendo esta edificada a partir das informações levantadas, interpretadas e/ou compreendidas, o que determinou as atividades seguintes.

\subsection{Uma aproximação com os conceitos da Análise Institucional/Movimento Institucionalista}

Segundo Lourau (1996), a gênese do pensamento institucional tem sua origem, pelo menos a partir da Antiguidade grega, configurando em um problema para a metafísica, filosofia e política. O autor ainda destaca a realização de uma obra de socioanálise, uma inversão na reflexão sobre a instituição que era baseada na situação de fato, implícita ou explícita. Em 1792, o filósofo Jean-Jacques Rousseau inaugura uma corrente da análise institucional para a qual o Estado não será mais a providência da vida social e passa a confiar

\footnotetext{
${ }^{5}$ BAREMBLITT, G. Compêndio de Análise Institucional e outras correntes. Teoria e Prática, de (2002). Cabe destacar que há várias correntes que integram o Movimento Institucionalista, constituindo-se em um conjunto de escolas e tendências.
} 
a legitimidade não mais à situação de fato e, sim, ao povo soberano. Nessa fase, o conceito de instituição foi muito mais detalhado pelos povos e homens políticos do que tinha sido estudado pelos teólogos e filósofos do direito ao longo de mil anos.

Mais recentemente, a Análise Institucional desenvolveu-se no campo das Ciências Humanas, promovendo uma diversidade de escolas e correntes. Barbier (1985) destacou quatro tipos de Análise Institucional, segundo suas publicações e práticas sociais: análise institucional socioanalítica ou socioanálise, sociopsicanálise institucional, análise institucional de inspiração sociológica e a esquizoanálise.

Uma delas é a Análise Institucional Socioanalítica, ou socioanálise, que foi desenvolvida por Georges Lapassade e Rene Lourau. A Análise Institucional Socioanalítica desenvolve uma intervenção a partir de um pedido de uma organização-cliente, orientada de acordo com os conceitos da Análise Institucional, numa situação criada pela instalação de um dispositivo analisador. A intervenção analítica refere-se às estruturas sociais visíveis e sobretudo invisíveis, às relações sociais antagônicas e veladas de que se compõe uma instituição (BARBIER, 1985).

Outra corrente é a Sociopsicanálise Institucional, que tem, entre seus representantes, Georges Mendel. É um método de análise coletiva que considera as manifestações do inconsciente, a problemática do poder institucional e o fato de cada trabalhador, dentro da instituição, pertencer a uma classe social definida pelo lugar que ocupa no processo de produção. A função dos sociopsicanalistas é detectar o fenômeno da autoridade que aparece nos grupos institucionalizados, tanto nas suas dimensões fantasmáticas de raízes pré-edipianas, quanto nas suas incidências políticas. Como método, visa analisar os grupos sociais homogêneos na instituição, para permitir o desvendamento das alienações específicas do político e a elaboração das posições e da consciência da classe social (BARBIER, 1985).

A terceira corrente é a Análise Institucional de inspiração sociológica, que pode ser observada nas publicações de Pierre Bourdieu e Jean Claude Passeron sobre o sistema de ensino institucionalizado e sua violência simbólica. Seu método é restrito à investigação tradicional da pesquisa sociológica, denominada análise institucional no papel, em razão do estudo de documentos e pesquisa de campo. Seu objeto são as relações que os homens possuem com as instituições, podendo confundir-se com a antropologia cultural e social (BARBIER, 1985).

A última corrente, a Esquizoanálise, pertence à linha do pensamento de Nietzsche e Reich, e tem em Gilles Deleuze e Felix Guattari seus propositores. Sua concepção está 
fundamentada no reconhecimento da máquina desejante, que é da ordem da produção e não da representação, conforme afirmado pela psicanálise. O objetivo da esquizoanálise é a raspagem, uma desconstrução do inconsciente, das crenças e representações, possibilitando que sujeitos passem por processos de desterritorializações e de reterritorializações. A Análise Institucional, na perspectiva da Esquizoanálise, consiste em ver que, por trás da hierarquia indivíduo/grupo/sociedade e suas várias modalidades sociológicas, movem-se interminavelmente constelações fluidas e instáveis de forças ativas e inertes que se organizam e se desorganizam ao sabor das crises, dos desejos e dos comprometimentos. Possuem a característica de ser provisório, o que sugere as qualidades de fluidez e dinamicidade do social (BARBIER, 1985).

Para Baremblitt (2002), as escolas e tendências do Movimento Institucionalista possuem características comuns que se configuram em ideais máximos do movimento e que podem ser traduzidas na sua proposição de propiciar, apoiar e deflagrar em coletivos, processos de autoanálise e autogestão. A autoanálise consiste em que os coletivos sejam protagonistas de seus problemas, necessidades, interesses, desejos e demandas, tornando-os capazes de enunciar, compreender, adquirir ou readquirir um pensamento e um vocabulário próprio, que lhes permitam conhecer a própria vida. Portanto, não se trata de que alguém venha de fora ou de cima para dizer-lhes quem são, o que podem, o que sabem, o que devem pedir e o que podem ou não conseguir. O processo de autoanálise ocorre simultaneamente com o de autogestão, em que o coletivo articula-se, institucionaliza-se, e se organiza para construir dispositivos necessários para produzir, ele mesmo, ou para conseguir os recursos de que precisa para a manutenção e o melhoramento de sua vida sobre a terra.

Esse conjunto de conceitos dá o suporte para que o percurso da pesquisa seja traçado e efetivado, assim como estabelece possibilidades para um movimento de criação de um campo de competência e responsabilidade na prática de saúde bucal na Estratégia Saúde da Família.

\subsubsection{As sociedades segundo a Socioanálise}

Com a finalidade de compreender a Pesquisa-intervenção, fundamentada na corrente da Socioanálise do Movimento Institucionalista ou Análise Institucional, é necessário que se apresentem alguns dos conceitos que lhe dão sustentação e são necessários ao seu 
entendimento, tais como sociedade, história, instituição, organização, estabelecimento e equipamento.

Como apontado acima, o Movimento Institucionalista possui dois objetivos básicos, a autoanálise e a autogestão. A “autoanálise” refere-se à capacidade de as comunidades serem protagonistas de seus problemas, de suas necessidades, de suas demandas, que possam enunciar, compreender, adquirir ou readquirir um vocabulário próprio que lhes permita saber sobre suas vidas. Simultaneamente, ocorre a "autogestão", caracterizada pela articulação da comunidade, pela sua institucionalização e pela sua organização, para construir os dispositivos para a obtenção de recursos necessários para o melhoramento de sua vida (BAREMBLITT, 2002).

Assim, segundo Baremblitt (2002), o institucionalismo aponta que a história não está relacionada ao registro dos fatos segundo datas de sua existência, mas um devir da sociedade no tempo, ou seja, transformação incessante e permanente pela qual as coisas se constroem e se dissolvem noutras coisas

Baremblitt (2002) traz os significados distintos de Sociedades e Instituições. A "Sociedade" é uma forma organizada de associação humana, é uma rede, um tecido de instituições. As "Instituições” são lógicas, árvores de composições lógicas que, segundo a forma e o grau de formalização que adotam, podem constituir-se em leis ou normas e, quando são apresentadas de forma manifesta, podem ser pautas ou regularidades de comportamentos. Uma instituição não necessita de uma formalização para ter suas leis, normas ou códigos escritos para existir, a exemplo das sociedades ágrafas, que também possuem seus códigos e são transmitidos de forma verbal. As lógicas significam a regulação de uma atividade humana, caracterizam uma atividade humana e se pronunciam valorativamente em relação a ela, clarificando o que deve ser, o que está prescrito, o que não deve ser, o que está proscrito e o que é indiferente.

Baremblitt (2002), ainda a respeito das Instituições, define-as como entidades abstratas e, para cumprirem sua função de regulação da vida humana, necessitam de materializar-se em dispositivos concretos, nas organizações. As "organizações" são formas materiais, muito variadas, que compreendem desde um grande complexo organizacional, a exemplo de um ministério, até um pequeno estabelecimento. Assim as organizações dão vida, concretizam uma realidade social que as instituições enunciam. Por outro lado, as organizações necessitam de objetivos, de sentido e de direcionamento, que são formulados pelas instituições. 
As “organizações", que são um complexo grande, possuem unidades menores, a exemplo dos estabelecimentos. Para Baremblitt (2002), os "Estabelecimentos" incluem dispositivos técnicos, exemplificados pelas maquinarias, instalações, arquivos, aparelhos e recebem o nome de equipamentos. Há situações em que esses equipamentos possuem uma realidade muito ampla, podendo formar um grande sistema de máquinas, um grande equipamento, formando uma situação em que a realidade material do equipamento coincida com o do estabelecimento.

Por último, Baremblitt (2002) fala a respeito do "agente", que são seres humanos, os mobilizadores, os suportes, os operadores, os protagonistas da atividade dessas unidades. Os agentes protagonizam práticas, as quais podem ser verbais, não verbais, discursivas ou não, práticas teóricas e, ou, técnicas. Essas unidades acabam operando transformações na realidade por meio das ações realizadas pelos agentes.

Com base nesses conceitos, podem-se identificar essas unidades no presente estudo. $\mathrm{O}$ Ministério da Saúde é a organização onde se materializam as leis, normas, diretrizes e pautas da instituição, o Sistema Único de Saúde (SUS). No arcabouço dessa instituição, localiza-se a proposta da Estratégia Saúde da Família e das Diretrizes Nacionais de Saúde Bucal. A USF Rubi é um estabelecimento da organização. Os agentes são os trabalhadores que compõem a equipe da USF Rubi.

Baremblitt (2002) ainda aponta que, em uma instituição, podem distinguir-se duas vertentes importantes. Uma é a vertente do "instituinte" e a outra é a do "instituído". "Instituinte" são os momentos de transformação institucional ou também as forças que tendem a transformar as instituições ou que tendem a criá-las. Em outras palavras, são forças produtivas de códigos institucionais. Esse grande momento inicial do processo constante de produção e de criação de instituições tem um produto, gera um resultado e este é o instituído. O "instituído" é o efeito da atividade instituinte.

O instituinte é um processo dinâmico. O instituído é o resultado e possui uma característica estática e congelada. O instituído cumpre um papel histórico importante, porque as leis criadas, as normas constituídas ou as pautas, os padrões, vigoram para regular as atividades sociais, essenciais à vida da sociedade.

As organizações também possuem uma vertente "organizada" e outra "organizante". A "organizante" refere-se a uma atividade permanentemente crítica e transformadora, que otimiza as organizações. O “organizado" pode ser exemplificado pelo famoso organograma ou fluxograma, 
que é necessário, mas que tem uma tendência histórica a esclerosar-se e a adotar uma série de vícios. A burocracia é o mais conhecido desses vícios.

Baremblitt (2002) destaca a importância de saber que, para que a vida social, entendida como o processo em permanente transformação que deve tender ao aperfeiçoamento, vise à maior felicidade, maior realização, maior saúde, maior criatividade de todos os membros, ela precisa ser regulada por instituições e organizações. É necessário também que a relação e a dialética entre o instituinte e o instituído, entre o organizante e o organizado (processo de institucionalização - organização) se mantenham permanentemente permeáveis, fluídas e elásticas na vida social.

Outras categorias de análise que permeiam as organizações, instituições, estabelecimentos, agentes e práticas são a "função" e o "funcionamento" e estão relacionadas às utopias sociais, segundo as quais as civilizações, sociedades ou grupamentos humanos constroem, à sua maneira, finalidades mais altas, objetivos mais nobres. A Revolução Francesa, exemplo desse tipo de utopia, contemplou diferentes formas de liberdade, igualdade, verdade e fraternidade. Entretanto, na vida humana tomada em um sentido amplo, a história mostra que três grandes situações viciosas, a dominação, a exploração e a mistificação - entendidas como desinformação ou engano-comprometem o objetivo utópico ativo.

Baremblitt (1992, p. 34) afirma que:

[...] cada sociedade em seus aspectos instituintes e organizantes, sempre tem uma utopia, uma orientação histórica de seus objetivos, que é desvirtuada ou comprometida por uma deformação que se resume em: exploração de uns homens pelos outros (expropriação da potência e do resultado produtivo de uns por parte dos outros), dominação, ou seja, imposição da vontade de uns sobre os outros e não respeito à vontade coletiva, compartilhada, de consenso, e mistificação, ou seja, uma administração arbitrária ou deformada do que se considera saber e verdade histórica, que é substituída por diversas formas de mentira, engano, ilusão, sonegação de informação etc.

A compreensão da oposição entre a utopia, no sentido do aperfeiçoamento da vida social e suas deformações, quer seja a exploração, a dominação ou a mistificação, facilita a compreensão de uma divisão que se estabelece entre função e funcionamento.

As instituições, organizações, estabelecimentos, agentes e práticas, na sociedade, apresentam uma função que está sempre a serviço das formas históricas de exploração, dominação e mistificação. Entretanto, essa função raramente se apresenta de forma clara, transparente, mas sim, deformada, como o objeto natural, desejado e lógico das instituições e das organizações, não se exprimindo claramente no nível do instituído e do organizado. Em outras palavras, os instituídos e os organizados estão, na maioria das vezes, a serviço da 
exploração, da dominação, da mistificação e manifestam essas deformações sociais de forma que pareçam naturais, desejáveis e eternas, ao passo que o instituinte e o organizante são sempre inspirados pela utopia. Essas forças e esses processos recebem o nome de funcionamento. $\mathrm{O}$ funcionamento é sempre instituinte, é sempre transformador, é sempre justiceiro e tende à utopia; por outro lado, a função é predominantemente reacionária, conservadora, está a serviço da exploração, da dominação e da mistificação e se apresenta aos olhos não atentos como eterna, natural, desejável e invariável.

Todos esses elementos conceituais permeiam a presente investigação, sustentando o trajeto e o processo de análise do empírico vivido, permitindo um caminho a ser percorrido pelo pesquisador cartógrafo que, junto com a equipe da USF Rubi, foi demarcando as possibilidades, assinalando as incertezas, removendo ou recolocando os pontos identificados como essenciais para a prática de Saúde Bucal pela equipe de saúde.

\subsection{Construindo o campo de análise e de intervenção da prática de saúde Bucal na USF Rubi}

O campo de análise refere-se à prática de Saúde Bucal de uma Equipe de Saúde Família, às suas limitações e às suas potencialidades para construir uma nova práxis que contemple os princípios descritos nas Diretrizes da Política Nacional de Saúde Bucal (BRASIL, 2004) e da Estratégia Saúde da Família (BRASIL, 2000b, 2001; 2007).

Este estudo foi realizado no município de Ribeirão Preto, São Paulo, Brasil, que possuía 604.682 habitantes em 2010 (IBGE, 2011). É uma das regiões mais ricas do Estado de São Paulo; tem bons indicadores sociais (saúde, educação e saneamento), localização privilegiada, próxima a importantes centros consumidores, e acesso facilitado, devido à boa qualidade da infraestrutura de transportes e comunicação. Destaca-se por constituir-se num polo de atração de atividades comerciais e de prestação de serviços, cuja área de influência extrapola os limites da própria região de governo, estendendo-se para as regiões de Franca, Barretos, São Carlos, São João da Boa Vista e outras cidades do próprio Estado de São Paulo e de outros estados. Também é um dos principais centros universitários e de pesquisa do Estado e do país. Ribeirão Preto destaca-se, também, pela qualidade de prestação de serviços na área da saúde (RIBEIRÃO PRETO, 2009).

Os serviços de atenção básica à saúde do município estão estruturados em cinco distritos de saúde; cada distrito conta com uma unidade Distrital, Unidades Básicas de Saúde 
(UBS) e Unidades de Saúde da Família (USF). Um dos distritos é o Distrito de Saúde Oeste, com uma população estimada em 141.998 habitantes, segundo as estimativas por distrito para o ano de 2009 (RIBEIRÃO PRETO, 2009) A Equipe de Saúde da Família que fez parte deste estudo localiza-se nesse distrito.

Os Núcleos de Saúde da Família (NSF), como são denominadas as USFs ligadas à Universidade de São Paulo (USP), são cogerenciados pela USP e Secretaria Municipal de Saúde de Ribeirão Preto. Esses núcleos possuiem, em cada equipe, um médico, um enfermeiro, dois técnicos ou auxiliares de enfermagem, cinco agentes comunitários de saúde (ACS) e uma população adstrita de aproximadamente 3.500 pessoas ou 800 famílias.

Cada NSF possui um coordenador docente, vinculado à USP, um médico com formação em Medicina da Família e Comunitária, uma enfermeira, duas auxiliares ou técnicas de enfermagem e cinco ACSs. Os núcleos constituem-se em campo de estágio curricular para os alunos dos cursos de graduação em Medicina, Enfermagem, Odontologia, Nutrição e Terapia Ocupacional; participam dos núcleos, também, acadêmicos e um docente de cada curso. Também é campo de estágio para os alunos residentes em Saúde da Família e Medicina Comunitária, e em Residência Multidisciplinar nas áreas de Nutrição, Farmácia, Fisioterapia e Fonoaudiologia e no curso de aprimoramento em Psicologia.

Com o propósito de selecionar o campo de intervenção, o projeto de pesquisa foi apresentado às USFs para obter aceitação para a realização do projeto nas unidades, mas, principalmente, tratava-se de ofertar à equipe uma atividade de construção coletiva de práticas de Saúde Bucal que poderia gerar na equipe, no mínimo, a demanda de conhecer esse campo de práticas ou mesmo de construir novas práticas.

O projeto de pesquisa foi apresentado às cinco USFs ligadas à USP. Em cada unidade, iniciou-se com uma breve apresentação do projeto, abordando-se a vivência do pesquisador em uma das unidades, as fundamentações teóricas do estudo, os objetivos da pesquisa, a metodologia de investigação, as contribuições da pesquisa para a equipe e, em seguida, foram apresentadas as dúvidas e a houve discussão sobre a viabilidade de execução do projeto na unidade.

Nessas discussões, foi possível verificar o interesse pelo projeto da equipe de cada unidade e, além disso, as USFs manifestaram-se formalmente no próprio projeto de pesquisa, o qual foi encaminhado à Direção Acadêmica da UBDS Citrino e disponibilizado aos pesquisadores posteriormente. 
As cinco USFs manifestaram-se favoráveis à execução do projeto em sua unidade. As unidades Prata e Safira fizeram ressalvas quanto à necessidade de acertar os horários para a pesquisa e a USF Rubi ressaltou seu interesse em vista da inserção do pesquisador na equipe, até aquele momento, como cirurgião-dentista; do fato de a pesquisa proporcionar retorno para a USF; da necessidade de interação dos conhecimentos da Saúde Bucal com as outras áreas de saúde e da possibilidade de crescimento e fortalecimento da equipe.

Em função da escolha do campo de intervenção, restava ainda discutir a implicação do pesquisador com as cinco unidades. Dentre elas, havia uma maior interação com as USFs Prata, Safira e Rubi devido às atividades de supervisão dos alunos de graduação da FORP/USP.

Nas duas primeiras unidades, a inserção ocorreu nos três últimos anos e nas três unidades as atividades realizadas eram as mesmas, de grupo de Odontologia, Consulta de Saúde Bucal e a participação pontual em reuniões de equipe para discussão de famílias.

O pesquisador trabalhava na equipe da USF Rubi desde sua criação, em 2001, e vivenciou, como membro da equipe, de dois processos: a construção do trabalho de aproximação aos modos de vida das famílias e compreensão dos processos de saúde-doençacuidado. Esses processos proporcionaram aos membros das equipes sentimentos de afetações, vínculo, pertencimento, em vista da dinâmica do trabalho desenvolvido e pelo reconhecimento dos usuários do trabalho realizado, pela coesão que o grupo de trabalhadores possuía em torno do modelo de saúde praticado e, por vezes, pela perda e frustrações devido aos desacertos entre os seus membros, ao sentimento de impotência frente a situações sociais familiares de difícil resolução e a falta de outras maneiras de lidar com as realidades. Durante esse processo, a equipe manteve-se coesa, mesmo com a substituição do médico e de uma das técnicas de enfermagem.

Assim, mediante a anuência das equipes e dos elementos acima considerados para a seleção do campo de intervenção, utilizou-se um quadro com os relatos das apresentações para cada unidade e, adicionalmente, com as manifestações formais do interesse da equipe na realização do projeto e com a implicação do pesquisador. Com os dados, concluiu-se que a USF Rubi demonstrou ser a melhor opção, pelo maior número de manifestações de interesse, de disponibilidade da equipe e da participação do pesquisador na unidade (Apêndice 1).

O campo de intervenção selecionado, portanto, foi a USF Rubi. A USF Rubi iniciou suas atividades no ano de 2001 e no seu território vivem e convivem, em sua grande maioria, famílias de classe média e pessoas idosas. Desenvolve grupos de atividade física para pessoas 
da terceira idade e de artesanato, de dança, de odontologia e de cuidadores para moradores de uma residência terapêutica para egressos do Hospital Psiquiátrico estadual sediado no município.

As reuniões de discussão de casos de família ocorrem rotineiramente às segundas e quintas-feiras, na primeira hora da manhã, em uma das salas de reunião da USF Rubi. Os objetivos das reuniões são apresentar informações das famílias da área, classificá-las para o risco de agravos à saúde e elaborar projetos terapêuticos. Participa da reunião a maioria dos membros da equipe, que se dispõem em uma roda, e todos podem apresentar famílias para discussão. A reunião quase sempre é coordenada pelo médico da unidade.

$\mathrm{Na}$ organização do trabalho da equipe, há elementos que a caracterizam como grupo, uma vez que geram relações sociais, interação entre atores sociais, ligados entre si por constantes de tempo e espaço e articulados por uma mútua representação interna, que se propõe de forma explícita a uma tarefa, quer seja, a discussão de casos de família (PICHONRIVIÉRE, 2005). Dessa forma, o processo grupal é gerado no cotidiano da equipe, independentemente da sua vontade e de ser consciente ou não. Dentre os vários tipos de grupo, podemos dizer que a equipe desenvolve, na maioria de seus encontros, um processo com elementos presentes no desenvolvimento de grupo operativo (PICHON-RIVIÉRE, 2005).

A produção dos dados foi realizada no período de fevereiro de 2010 a fevereiro de 2011, por meio de gravação de áudio das reuniões administrativas, discussões de caso; registro em diário de campo, registros das reuniões da equipe, do grupo de pesquisa e também foram utilizados os registros da equipe existentes na USF Rubi (atas produzidas pela USF). Posteriormente, as gravações foram transcritas pelo pesquisador. Assim, o material empírico desta investigação é constituído por um conjunto de registros oriundos das transcrições das atividades grupais (reuniões administrativas e discussões de caso), de narrativas6 produzidas pelo pesquisador sobre as atividades vivenciadas por ele junto à equipe da USF Rubi, sínteses

\footnotetext{
${ }^{6}$ Narrativa "é uma tradição de contar um acontecimento em forma sequencial, cuja composição mais simples inclui começo, meio e fim, e tem, em sua estrutura, cinco elementos essenciais: o enredo (conjunto de fatos); as/os personagens (quem faz a ação); o tempo (época em que se passa a história, duração da história); o espaço (lugar onde se passa a ação) e o ambiente (espaço carregado de características socioeconômicas, morais e psicológicas onde vivem as/os personagens) [...] Ao narrar um acontecimento, a pessoa reorganiza sua experiência, de modo que ela tenha ordem coerente e significativa, dando um sentido ao evento. 'É uma expressão simbólica que explica e instrui como entender o que está acontecendo’ (SILVA, TRENTINI, 2002, p. 425).
} 
devolvidas à equipe sobre às discussões processadas (como, por exemplo, a construção da agenda) e registros da própria equipe.

\subsection{Aspectos éticos necessários à entrada no campo e à realização da pesquisa}

Por tratar-se de uma pesquisa que envolve a participação de seres humanos, foram cumpridas todas as exigências da Resolução CNS 196/96, garantindo-se toda a proteção dos sujeitos da pesquisa. Foi solicitada a anuência dos responsáveis pelo serviço de saúde e o projeto foi submetido à avaliação do Comitê de Ética em Pesquisa do Centro de Saúde Escola “Dr. Joel Domingos Machado". O projeto foi aprovado mediante Parecer n 323/CEPCSE/FMRP-USP.

Cabe, mais uma vez, ressaltar que, antes do início das atividades de campo, foram apresentados aos participantes membros das equipes o projeto e seu conteúdo e, principalmente, o método de pesquisa adotado, seus procedimentos e técnicas de coleta de dados, esclarecendo que a investigação não traria risco para os participantes e mostrando quais benefícios o projeto traria para a equipe da USF Rubi, selecionada para seu desenvolvimento. $\mathrm{O}$ pesquisador, neste momento, reafirmou a garantia de confidencialidade e anonimato e o direito de o participante interromper sua participação na pesquisa, sem que houvesse prejuízos. Para a etapa efetiva de desenvolvimento da pesquisa, a aceitação dos participantes foi formalizada por meio do Termo de Consentimento Livre e Esclarecido, fornecido pelo pesquisador (Apêndice II).

\subsection{Construindo as etapas da Pesquisa-intervenção}

\subsubsection{A sensibilidade da equipe da USF Rubi com questões de Saúde Bucal}

Na implantação da USF Rubi, as discussões em torno da organização da Saúde Bucal na unidade de saúde eram mais frequentes e contavam com a participação dos trabalhadores da equipe. Foi possível discutir, nas reuniões administrativas, a proposta de realização de um grupo de odontologia, que tinha o propósito de possibilitar o acesso dos usuários ao serviço; 
de criar a consulta de Saúde Bucal, que tinha como novidade uma ação de Saúde Bucal que não usava cadeira odontológica, mas uma integração às outras áreas de saúde; de trabalhar com um prontuário único; de conhecer a dinâmica familiar; de deixar a equipe ser conhecida pela família; de criar vínculo entre família e dentista; de promover a prevenção de doenças bucais e a promoção à saúde, e de preparar o usuário para receber o atendimento odontológico na Unidade Distrital de referência, em um agendamento contínuo. Foi um dos momentos em que a equipe se mostrou mais motivada a discutir a Saúde Bucal, como também a participar das atividades de grupo e reforçar, junto à população, a necessidade de um segmento odontológico que garantisse ações de prevenção e promoção de Saúde Bucal.

Em um segundo momento, a equipe da USF Rubi passou a demonstrar interesse por algumas questões de Saúde Bucal, que se transformaram em temas para reuniões de Educação Permanente. Esses temas foram abordados por alunos do curso de graduação em Odontologia (FORP-USP) em estágio na USF Rubi, com apresentações breves, de duração de uma hora, que explicavam o uso de fluoretos e dentifrícios, ensinavam cuidados com próteses, lesões bucais e medição da capacidade-tampão da saliva. Tratava-se de questões pontuais, cuja abordagem pode não ter sido suficiente para estimular a sua inclusão no cuidado à saúde ou que atenderam ao interesse particular. Não há uma avaliação precisa do quanto foi incorporado ao cuidado prestado pela equipe nos diferentes espaços de produção do cuidado em saúde. Entretanto, foi possível observar um interesse crescente da equipe pela Saúde Bucal dos usuários.

A apresentação do projeto na USF Rubi para obter a aprovação de sua realização, que se constituiu em uma oferta para a equipe para uma construção coletiva, foi considerado um disparador importante e desencadeou uma demanda por parte da equipe. Ofertou-se às USF uma intervenção, explicou-se, a cada equipe, que o projeto tratava de um estudo sobre trabalho em equipe, da constituição de um campo de competência e responsabilidade para a Saúde da Família, fundamentado na Atenção Primária à Saúde, na Estratégia Saúde da Família, nas Diretrizes Nacionais de Saúde Bucal, que tinha como objetivos a construção coletiva de saberes e práticas de Saúde Bucal, assim como são os objetivos da pesquisa e o método de PI.

A oferta de intervenção originou expectativas expressas na discussão e no parecer da USF Rubi (Apêndice 1). Constatou-se a receptividade da equipe ao projeto e ao pesquisador, provavelmente também em função da sua inserção na equipe. 
Destacam-se duas demandas relacionadas ao objeto deste estudo: o interesse da equipe com relação a uma mudança, verbalizada "pelo fato de a pesquisa proporcionar retorno para o serviço" (Reunião Administrativa - 15/06/2009 ) e o interesse pelo trabalho em equipe do "tipo integração", em que os saberes integram-se, expressos na "necessidade de interagir os conhecimentos de Saúde Bucal com as outras áreas de saúde" (Reunião Administrativa $15 / 06 / 2009)$.

A equipe, para se manifestar de forma favorável à realização dessa intervenção, parece ter levado em consideração o fato de a pesquisa não ter o sentido apenas de coleta de dados, numa perspectiva de externalidade ao objeto da pesquisa, o que tem sido alvo de críticas por seus profissionais a outras pesquisas com as mesmas características.

Surgiram, durante a realização da reunião de apresentação da proposta à equipe, dizeres, tais como: "fato de a pesquisa proporcionar retorno para o serviço"; "crescimento e fortalecimento da equipe e produtos gerados pela pesquisa” (Reunião da USF Rubi), que traduziram uma expectativa com o aprimoramento do trabalho da equipe.

\subsubsection{Qual o desejo da equipe?}

Para Baremblitt (1992), demanda e encargo são inseparáveis e nunca coincidentes, pois a demanda é a solicitação formal, consciente, deliberada, e o encargo revela o real desejo e o inconsciente. A diferença entre eles pode ser explicado por meio de três tipos de determinações: a má fé, o desconhecimento ou o recalque.

A apresentação do projeto de pesquisa foi a oferta de um trabalho com a equipe, caracterizada pela construção coletiva de saberes e práticas em Saúde Bucal. A equipe na USF Rubi manifestou interesse, justificado pela necessidade de se integrar com esta área de conhecimento, pela inserção do pesquisador na equipe como cirurgião-dentista, que se dispõs a trabalhar coletivamente com os sujeitos da pesquisa e pela metodologia utilizada pelo projeto, configurando a demanda da USF Rubi com relação a este estudo.

Essa demanda pode ter sido formada pelas expectativas da equipe em torno de uma produção coletiva de novas práticas e saberes interdisciplinares para a atenção à Saúde Bucal da população de referência da USF, uma vez que a equipe demonstrava interesse pela organização da área e temas específicos. Esse desejo levaria à introdução de novas práticas de 
saúde no cotidiano do trabalho de todos os profissionais de saúde e de um novo comprometimento, o da atenção à Saúde Bucal. Isto faria que se coincidissem a oferta e a demanda.

Por outro lado, os profissionais da equipe compreenderam que essa interação de conhecimentos levaria a um incremento de atividades já realizadas e estaria disposta a assumila? Do ponto de vista teórico, da proposta da PI, nessa etapa iniciou-se a construção de um diagnóstico que subsidiou o planejamento da intervenção. Esse diagnóstico foi realizado por meio dos analisadores, identificados no processo de intervenção.

\subsubsection{Analisadores}

Segundo Lourau (1976), o dispositivo analisador vai desconstróir o instituído como forma das relações sociais dominantes e forma dominante do saber social mergulhado na impotência. Lourau (1976), afirma ainda que o analisador provoca a verdade da situação, fornece uma informação máxima sobre as implicações de cada um e indica sabiamente o local escondido do poder.

Segundo Baremblitt (1992), o conceito de analisador tem sua origem na Psiquiatria e está relacionado aos derivados do inconsciente, formação do inconsciente, formações transicionais ou transacionais, que são termos sinônimos, e referem-se aos sonhos, atos falho, entre outros pontos. Os analisadores podem ser históricos quando a própria vida histórica, social e natural os produz por conta própria, como resultado de suas determinações, ou construídos, que são dispositivos que os analistas institucionais inventam, introduzem nas organizações para provocar o processo de explicitação de seus conflitos e resolução. (BAREMBLITT, 1992).

Baremblitt (1992) enfatiza que os analistas institucionais, em sua prática, ao produzirem analisadores construídos, valem-se de todo e qualquer recurso do tipo artístico, cenográfico, dramático e outros, de forma que o analisador institucional passa a fazer parte orgânica do conjunto que vai estudar, produzindo, assim, um artefato próximo da vida cotidiana.

Para efeitos desta pesquisa, três situações foram consideradas como analisadores: 
- Revendo a agenda da Saúde Bucal da equipe da USF Rubi: A situação analisadora foi a organização da agenda dos atendimentos de Saúde Bucal, que foi discutida pela equipe nas reuniões administrativas. A agenda ocupou a pauta em cinco reuniões.

- A equipe e uma de suas famílias: o caso da família do Sabiá Laranjeira: Dentre as famílias que foram acompanhadas, uma delas foi a mais representativa do processo de trabalho da equipe, devido à sua complexidade, por gerar implicações e afetações na equipe, revelando o seu modo de funcionamento. Este estudo utilizou, portanto, as transcrições das discussões desse caso, com a utilização de nove discussões transcritas ou narrativas produzidas pelo pesquisador.

- Discutindo a Saúde Bucal com a equipe da USF Rubi: A situação analisadora foi um momento de reunião de equipe destinada à discussão sobre Saúde Bucal na USF Rubi, em que se utilizou um dispositivo para mobilizar os participantes para o processo de reflexão, fundamentado nas Diretrizes Nacionais de Saúde Bucal (BRASIL, 2004).

\subsubsection{Diagnóstico provisório e planejamento preliminar}

Com base nas informações obtidas pela análise da sensibilidade da equipe com relação à Saúde Bucal (o real desejo da equipe, a análise de implicação e o produto da análise dos analisadores), elaboramos um diagnóstico provisório e um planejamento de táticas, políticas e estratégias para serem utilizados junto aos profissionais da equipe.

Embora o diagnóstico provisório não seja completo (e não se espera que efetivamente o esteja), foram estabelecidos analisadores artificiais ou dispositivos para recolher dados para compor o diagnóstico, para criar condições para os profissionais expressarem o que ainda se encontrava velado. $\mathrm{O}$ objetivo desses analisadores é agitar o ambiente e gerar um material mais profundo, mais crítico e mais comprometido.

Esses analisadores podem ser um dispositivo que vá propor a discussão de uma forma indireta, deslocando a problemática da situação espontaneamente mencionada, a exemplo de um filme ou a seleção de uma situação vivenciada. Por outro lado, essa forma não é indutiva, porque o interventor não estabelece regras, não propõe um dispositivo agitador, um agenciamento ativador.

Assim, alguns analisadores foram propostos no desenvolvimento da investigação e desencadearam processos de desterritorialização e reterritorialização e possibilitaram destacar 
o funcionamento, o instituído, o instituinte, as subjetivações e subjetividades no processo de trabalho da equipe.

\subsubsection{Diagnóstico de planejamento definitivo}

Depois de executados os dispositivos do diagnóstico provisório, foram analisados os dados coletados e produzida a análise da demanda e do encargo definitivo.

Também foi necessário que o pesquisador realizasse a autoanálise da implicação, uma vez que ativamos ou mobilizamos um coletivo e o colocamos em condição de manifestar-se muito mais livremente, muito mais ricamente, mas ao mesmo tempo também fomos mobilizados, fomos igualmente ativados. Deve-se perguntar o que foi que este processo acordou, despertou em nós, e que não tínhamos percebido em todos os passos anteriores.

Nessa etapa foram elaboradas novas táticas, políticas e estratégias de intervenção,e foram construídos analisadores definitivos. Foram discutidos com a equipe a nova proposta de intervenção e um contrato de intervenção que requereu mais retribuição, envolveu maior compromisso e exigiu maior clareza quanto aquilo com o que estava se lidando e quais foram as ressonâncias inconscientes que foram despertadas.

Após executada a intervenção conforme planejada, foram realizadas as avaliações periódicas que são momentos de parada para identificar os resultados e voltar a analisar a implicação que se vinha gerando, os índices de transferências, resistência, produção, antiprodução, atravessamento e transversalidade.

No percurso desta investigação, foi possível restituir à equipe as sínteses das reuniões administrativas, apresentar os produtos gerados pela própria equipe neste processo e realizar intervenções que tiveram a intencionalidade de motivar a equipe a desenvolver a autoanálise e a autogestão, no sentido da criação de um campo de competência e responsabilidade de Saúde Bucal Coletiva.

Assim, para o processo de análise, uma vez constituído o corpus da pesquisa e considerados os analisadores utilizados para o processo de reflexão junto à equipe, mediante a análise de conteúdo em sua vertente temática (MINAYO, 2004), foram identificados e analisados quatro temas:

- Relações estabelecidas entre os atores disciplinares;

- A assistência, atenção e a clínica ampliada na Equipe Rubi;

- Alienação no processo de produção de cuidado em saúde pelo USF Rubi;

- A Saúde Bucal na arena da Atenção Básica e da Estratégia Saúde da Família. 


\section{Ofertando uma viagem sobre a discussão em torno da prática de Saúde Bucal - modulando a demanda nas equipes}

Como já vem sendo apontado, o campo de análise desta investigação refere-se à prática de Saúde Bucal na Estratégia Saúde da Família, suas limitações e potencialidades na direção da construção de uma práxis que contemple os princípios e diretrizes do SUS bem como aqueles descritos nas Diretrizes da Política Nacional de Saúde Bucal (BRASIL, 2004) e da ESF (BRASIL, 2000b, 2001; 2007). Essas diretrizes recomendam que as equipes de Saúde da Família desempenhem uma nova prática social de saúde pautada pela interdisciplinaridade e, especificamente, pela inclusão da Saúde Bucal na organização do processo de trabalho da equipe, assegurando, no plano macro, ou seja, das políticas de saúde pública no Brasil, o resgate dos cuidados em Saúde Bucal nos processos de saúde-doença e cuidado das unidades de saúde do SUS.

Neste estudo, buscamos compreender a construção desta prática social no espaço micro da sociedade, porque as pequenas mudanças ocorrem nos pequenos lugares intersticiais da vida natural, social, técnica e subjetiva, o plano em que ocorrem as pequenas mudanças, onde se localizam o instituinte, o desejo, a produção do novo e, ao se conectarem, resultam nas grandes mudanças (BAREMBLITT, 1992). Esse micro espaço no presente estudo é uma das USFs do município de Ribeirão Preto.

Com o propósito de identificar, entre as equipes de Saúde da Família, a unidade em que a oferta da pesquisa poderia suscitar demandas com relação à Saúde Bucal, o projeto de pesquisa foi apresentado ao Centro de Atenção Primária da FMRP/USP (CAP), com possibilidade de encaminhamento para as cinco USFs da área básica da UBDS Citrino, vinculadas à USP, como já apontado anteriormente. Expôs-se o projeto para cada equipe, para que fossem mostradas suas ideias principais, para que se verificassem o interesse e a receptividade ao trabalho e para que o resultado dessas ações fornecessem subsídios para possibilitar a seleção do campo de intervenção.

As apresentações foram previamente agendadas e compuseram a pauta de reunião de cada unidade; realizou-se uma exposição para cada USF. Todas as apresentações ocorreram no mês de maio de 2009, entre os dias 15 e 26, e tiveram uma duração média de 20 minutos. Para a USF Esmeralda, a apresentação foi realizada durante a reunião de discussão de casos de família e alguns profissionais estavam ausentes. Para as demais USFs, as apresentações ocorreram 
durante a reunião administrativa da unidade e contaram com a participação da maioria dos membros da equipe.

Iniciamos a apresentação com uma breve exposição. Falou-se da motivação para este estudo, a partir da experiência na construção do trabalho em equipe na USF Rubi e da preocupação com construção de uma prática de Saúde Bucal, que se fundamenta nos princípios da Atenção Primária à Saúde, Estratégia Saúde da Família e Diretrizes Nacionais de Saúde Bucal. Expusemos o objetivo da pesquisa voltada para a compreensão da construção da prática de Saúde Bucal em uma equipe de Saúde da Família, como formador de um campo de saberes e de práticas. Finalmente, comentamos a metodologia de investigação, destacando as características da pesquisa participante, em que todos são pesquisadores e geram produtos para o serviço e as possíveis contribuições da pesquisa para a equipe da USF. Em seguida, abrimos a palavra para os profissionais da unidade para esclarecimentos das dúvidas e discussão a respeito do interesse e viabilidade de execução do projeto na unidade. Essa rotina de exposição dos projetos de pesquisa é usual nas USFs ligadas à USP.

Nas discussões, de uma forma geral, houve manifestação de interesse pelo projeto de investigação e concordância para participação, bem como comentários de que o trabalho seria importante para a unidade. Observou-se que este projeto diferenciava-se dos demais porque ofereceria um possível retorno para a equipe.

Nas USF Prata e Safira, foram feitas ressalvas a respeito das dificuldades para a operacionalização da coleta de dados, em razão da sobrecarga de trabalho das equipes e da existência de outros projetos de pesquisa em andamento nas unidades, o que aumentava a sobrecarga de trabalho dos profissionais.

Na USF Safira, foi relatada a dificuldade em garantir a participação da maioria da equipe nos momentos da coleta de dados. O docente da Faculdade de Odontologia apoiou e justificou a realização do projeto nesta unidade, e o dentista concordou com a sua realização.

Na USF Ônix, o docente coordenador da equipe, também orientador deste estudo, estava ausente, o que possibilitou que os profissionais pudessem manifestar-se livremente. Nessa unidade, os profissionais relataram dificuldades de horário para realização do projeto e tentaram encontrar alternativas para possibilitar a sua realização. A USF Ônix foi a unidade em que o seu cirurgião-dentista justificou seu interesse na participação no projeto.

Na USF Esmeralda, o docente coordenador da equipe também estava ausente e a discussão centrou-se no receio de o pesquisador definir unilateralmente temas para a equipe discutir e gerar possíveis alterações no atendimento à população. 
Na USF Rubi, contamos com a participação do coorientador deste estudo, que também é membro da equipe e que colaborou na discussão, valorizando as características da metodologia com relação à participação dos profissionais como atores da pesquisa e as possibilidades de retorno para o serviço. As manifestações dos profissionais da equipe valorizaram a inserção do pesquisador na equipe desde a sua criação, a existência de um trabalho voltado à inclusão da Saúde Bucal na prática de saúde da equipe, a necessidade de aumentar a interação dos conhecimentos da área de Saúde Bucal com as outras áreas da saúde e o fato de a pesquisa proporcionar, para o serviço de saúde, e em específico para a equipe, um ganho na forma de produtos técnicos e conhecimento, levando ao fortalecimento da USF.

Ao encerrarmos a apresentação, informamos que, após recebermos a manifestação formal do CAP e a verificação de qual unidade apresentaria as melhores condições para a pesquisa ser desenvolvida, faríamos contato para comunicar a indicação da unidade e o agendamento do início do estudo.

Quanto às manifestações formais, realizadas por meio de parecer no projeto de pesquisa, as USF Ônix, Rubi e a Prata foram as primeiras a manifestarem-se. As cinco USFs expressaram-se favoráveis em participar do projeto (APÊNDICE 1).

Os pareceres das USF Safira e Esmeralda limitaram-se em afirmar que estavam de acordo. A USF Prata chamou a atenção para a necessidade de se discutir um horário para viabilização da investigação, em função de outro projeto de pesquisa, que demandaria muito tempo da reunião e da equipe. A USF Ônix fez ressalva para a necessidade de acertar os horários para a pesquisa. A USF Rubi destacou o tempo considerável que o pesquisador já trabalhava com a equipe, aprovou a pesquisa-ação como metodologia eleita, recomendou ao pesquisador realizar o projeto na unidade e afirmou que a equipe foi bastante receptiva aos objetivos da pesquisa e à questão a ser investigada.

\subsection{Implicações do pesquisador}

Os dados produzidos no percurso deste estudo serão historiados segundo a compreensão da história pelo Movimento Institucionalista (BAREMBLITT, 1992), ou seja, histórias têm o sentido de ser um processo de conhecimento que pretende reconstruir os acontecimentos nos tempos. Assume-se que essa reconstrução é feita a partir da perspectiva do próprio Movimento Institucionalista, do processo de trabalho em equipe, da Atenção Primária à Saúde, da Saúde 
Coletiva, da Saúde Bucal Coletiva e da Estratégia Saúde da Família e que seus registros incluem os desejos, os interesses e as tendências de quem faz a História, o que se denomina implicação.

Assim, resta discutir a implicação do pesquisador com relação a este estudo e a indicação de uma unidade para o desenvolvimento da investigação. Embora o pesquisador mantivesse contato com os cinco USFs desde o início das suas atividades, houve uma maior interação com as USF Prata, Rubi e Esmeralda, em função das atividades de supervisão junto aos alunos de graduação da FORP/USP, assim como da realização das ações de Saúde Bucal e acompanhamento de famílias, tais como atividades de Grupo de Odontologia, Consulta de Saúde Bucal e a participação em reuniões administrativas e reuniões de equipe para discussão de casos de famílias. Nas USF Prata e Esmeralda, a inserção ocorreu mais recentemente, a partir de 2007 e 2009, respectivamente, e as atividades ficaram restritas a supervisão dos alunos.

O pesquisador trabalha com a equipe Rubi desde sua implantação, em 2001, o que tornou-lhe possível vivenciar, como dentista dessa equipe, a sua instalação, organização e desenvolvimento. Assim, foi possível acompanhar, desde a montagem dos espaços físicos da unidade, a territorialização e cadastramento de famílias da sua área de referência, a estruturação das reuniões de discussões de casos de família e administrativas, os primeiros atendimentos dos usuários da comunidade, o planejamento, realização e avaliação dos primeiros grupos de reeducação alimentar, saúde da mulher e hipertensão arterial.

Nos momentos iniciais da unidade, tratava-se, nas reuniões administrativas, de assuntos relacionados à organização do trabalho na unidade, desde a forma de discussão das famílias, motivação para compreender a reunião administrativa como assembleia e local privilegiado para discussões e tomada de decisões, planejamento semanal, mensal e anual das ações da unidade, até as questões de assistência e as de ensino.

A USF Rubi possuía três coordenadores, que tinham uma utopia ativa (BAREMBLITT, $1992)^{7}$ com relação à construção de um processo de trabalho da equipe pautado pelos princípios do SUS e diretrizes da ESF, especialmente no que se refere à interdisciplinaridade, humanização do cuidado e atribuição dos mesmos valores entre as ações de recuperação e as de

\footnotetext{
${ }^{7}$ Para o Movimento Institucionalista, utopia ativa denomina as metas e objetivos mais altos e nobres que orientam os processos produtivos-desejantes-revolucionários dos movimentos e agenciamentos sociais, em seus aspectos instituintes e organizantes e que não estão colocadas em um futuro remoto ou terminal, a exemplo do "Fim dos Tempos". A utopia ativa possui uma imanência entre fins e meios, ou seja, o processo produtivo-desejante-revolucionário é seu próprio fim e meio em cada aqui e agora (BAREMBLITT, 2002).
} 
prevenção e promoção de saúde, tal como as consultas de saúde e a Festa Junina, Feira de Talentos, Programa de Integração da Comunidade e Tarde da Beleza. Aos poucos, a maioria dos trabalhadores da equipe passou a compartilhar essa utopia ativa no seu cotidiano. As ações inovadoras eram compartilhadas e apoiadas pela equipe e algumas reconhecidas pela comunidade. A relação entre os membros da equipe era de compartilhamento e solidariedade, mas também de reflexão e discussão exaustiva, que passavam pelos processos de avaliação, planejamento e execução de ações, momentos que revelavam a existência de divergências internas e que produziam momentos de tensão, mas também de pertença. Havia uma espécie de ritual: após as reuniões de discussão de casos de família e administrativas, havia um breve café da manhã, um ágape, para fortalecer as relações e a fraternidade, um novo compartilhar pelo café e pelo pão.

Esse contexto propiciou que a inserção do pesquisador na unidade se voltasse para a construção de uma prática de saúde direcionada à atenção à saúde da população, e não exclusiva da Saúde Bucal. Assim, foram possíveis uma aproximação para a construção coletiva dos projetos terapêuticos, uma ampliação da compreensão do processo saúde-doença-cuidado para além do recorte biológico e um compartilhamento das frustrações geradas pelas famílias que possuíam uma circunstância de saúde e social complexa. A vivência com a equipe e as longas discussões sobre a organização do seu processo de trabalho, muitas delas árduas, fortaleciam a crença nos profissionais a respeito do trabalho em equipe ser uma forma de qualificar o cuidado em saúde na USF.

Também foi possível compartilhar com a equipe a criação e implantação de ações de Saúde Bucal. Uma delas foi o Grupo de Saúde Bucal, que tinha o objetivo de acolher os usuários que buscavam tratamento odontológico, mas também educativo, para estimular hábitos para manutenção da Saúde Bucal, do funcionamento do serviço e da Estratégia Saúde da Família. A outra foi a consulta de Saúde Bucal, que tratava de realizar, em um ambiente de consultório comum, todas as seguintes atividades indispensáveis ao tratamento odontológico e que não necessitavam de equipamentos: mapa genealógico, elaboração da história de saúde, aferição da pressão arterial, teste de glicemia capilar, classificação para tabagismo e etilismo, elaboração de queixas relacionadas à Saúde Bucal, teste de fluxo salivar e classificação para o risco de cárie dentária, doença periodontal, câncer de boca e disfunção temporomandibular e planejamento de ações de controle e prevenção. Embora esse elenco de procedimentos tivesse a intenção de investigar riscos para o adoecimento bucal e possuísse formato de protocolo, havia também os propósitos de criar vínculo entre o profissional e o usuário e de tornar os momentos 
da consulta um local privilegiado para o cuidado em saúde interdisciplinar, uma vez que abordavam-se questões a respeito da sua saúde e da vida, como hipertensão arterial, glicemia, afetividade na relação familiar, emprego ou subemprego. Essas circunstâncias foram compartilhadas com a equipe por meio das discussões de casos de família e do registro em prontuário individual, inclusive a respeito da Saúde Bucal, tomando-se o cuidado de utilizar linguagem apropriada para a compreensão de todos os profissionais.

Embora a equipe multiprofissional da USF Rubi construísse um processo de trabalho que buscasse romper com o isolamento disciplinar e construir práticas e saberes interdisciplinares, na maioria das vezes, o que ocorria era a sobreposição de conhecimento das diversas disciplinas. Contudo, esse processo foi pautado pela discussão participativa e construção coletiva dos projetos terapêuticos.

Como um conjunto de pessoas reunidas periodicamente, a equipe da USF Rubi desenvolveu um processo grupal, vivendo as tensões entre a fusão e a serialidade, em função do receio de voltar a ser série, o que poderia levar à dispersão do grupo. Essa luta é a primeira característica do grupo e é superada quando os seus membros se ligam por meio de um juramento.. A segunda característica do grupo é a sua constituição como grupo, definida como ato, um ato do grupo em si mesmo, que o leva a trabalhar incessantemente (LAPASSADE, 1977). Esse processo levou o grupo a formular regras que permitissem a sua manutenção, tais como a participação de todos nas reuniões, discussão dos problemas da equipe apenas nas reuniões, atenção afetuosa entre os participantes com relação ao bem-estar de cada um e a crença de que s USF Rubi é "a equipe que deu certo". Também se criaram regras de comunicação entre seus participantes, como a proibição de mencionar os nomes das pessoas em discussão de casos e família, identificando-os apenas pelo número da família.

Esses processos proporcionaram aos membros da equipe sentimentos da ordem de ganhos e satisfações, em vista do reconhecimento por parte dos usuários do trabalho realizado, da credibilidade no modelo de saúde praticado e, por vezes, de perda e frustrações, em razão dos desacertos entre os seus membros, do sentimento de impotência frente a situações sociais familiares complexas, situações para as quais, a ausência de instrumentos de trabalho, principalmente para lidar com famílias intersetoriais, por exemplo, tornava a resolução impraticável. 
Entretanto, nesse percurso, apareceram muitas dificuldades para a construção de um campo de conhecimento em Saúde Bucal pela equipe, a ponto de não incluí-la na práxis do cuidado à saúde dos seus membros. O pesquisador foi levado a elaborar essa situação como um problema a ser investigado e, mais tarde, como objeto de pesquisa em sua tese de doutorado.

Cabe acrescentar que, a partir do ano de 2007, a equipe passou por movimentos organizacionais distintos, que a levaram a uma gradual mudança do seu processo de trabalho e, consequentemente, à perda da motivação para a construção coletiva de uma alternativa para o cuidado em saúde centrada na proposta da Estratégia Saúde da Família. Dentre essas situações, destaca-se a substituição gradual dos coordenadores da USF Rubi e, em seguida, dos dirigentes das organizações que tinham relação direta com a USF, o que imprimiu novas diretrizes de trabalho. Aconteceu a rotatividade dos profissionais: médico, auxiliar de enfermagem e agente comunitário de saúde. A USF Rubi passou quatro meses sem um profissional médico na equipe. Ainda, somando-se a esse quadro, inseriram-se, na equipe, novos alunos de graduação, aprimoramento e residência multiprofissionais, docentes e profissionais de áreas da saúde que, em algumas situações, corresponderam à primeira aproximação com o serviço de saúde de Atenção Primária à Saúde.

A luta legítima dos agentes comunitários de saúde pelo reconhecimento da profissão e por melhorias profissionais e salariais, culminou com a incorporação desses agentes de saúde no quadro de funcionários públicos da Prefeitura Municipal de Ribeirão Preto ${ }^{8}$, o que gerou fortalecimento da instituição Secretaria Municipal de Saúde de Ribeirão Preto na arena da equipe. A efetivação dos agentes comunitários de saúde trouxe benefícios para o serviço e a população, mas também fortaleceu as tensões entre as instituições presentes na unidade, gerando estresse e desgaste na equipe.

Assim, o dentista pesquisador deste estudo esteve e está imerso nesse processo grupal e da construção do processo de trabalho da USF Rubi, e, portanto, desejante de que o estudo fosse realizado nessa unidade.

\footnotetext{
${ }^{8}$ O Ministério da Saúde criou Programa de Agentes Comunitários de Saúde em 1991 e, em 2002, reconheceu o Agente Comunitário de Saúde (ACS) como profissional vinculado ao Sistema Único de Saúde. Em 2006 foi criada a possibilidade de os ACSs passarem a fazer parte do quadro de Funcionários Públicos da Federação, Estado e Município, dispensando o concurso público, desde que tivessem, dentre outras exigências, passado por processo seletivo público até a data de Promulgação da Emenda Constitucional No 51 de 14 de fevereiro de 2006.
} 


\subsection{Caminho empreendido e a constituição dos analisadores}

Assim, para a seleção do campo de intervenção, utilizamos dados obtidos durante a apresentação da proposta, referentes ao interesse da equipe pela apresentação, pela pesquisa e manifestada no parecer emitido pela USF Rubi à Direção Acadêmica da UBDS Citrino. Diante de um quadro que retrata esses dados, foi possível destacar que a USF Rubi demonstrou ser a opção mais adequada em vista do interesse e disponibilidade da equipe e inserção do pesquisador (Apêndice 1).

Selecionado o campo de intervenção, assumimos, junto à USF Rubi, o papel de dentistapesquisador, em fevereiro de 2010, e iniciarmos a produção dos dados.

Deparamos com uma situação peculiar e imediata na produção dos dados: o estranhamento com algo que a equipe entendeu como um intruso nas reuniões, o gravador de áudio, utilizado para o registro das reuniões. Foi perceptível, pelos comentários, o incômodo causado pelo gravador, porque alimentou algumas fantasias. Por exemplo, especulava-se quem escutaria as gravações; os participantes tinham a sensação de estarem falando para pessoas não presentes à reunião ou de estarem sendo avaliadas posteriormente. Essas impressões causaram uma mudança na atitude dos participantes na reunião. Uma das formas para compreendermos esta reação à observação pode estar relacionada à organização da equipe da USF Rubi, enquanto grupo.

Nos momentos de formação do grupo, a fusão da serialidade, que significa a liquidação, desreificação, descristalização ou degelo, levando ao nascimento do grupo por meio de uma brusca totalização da série, cria uma espécie de ser comum, mas que já coloca cada participante como foco das ações do grupo. O término da vivência da fusão é marcado pelo risco de dissolver-se novamente na serialidade e isso mobiliza o grupo a organizar-se como tal, realizando um estatuto de permanência no grupo, o juramento. Institui o poder de cada um sobre todos e de todos sobre cada um. É o lugar do nascimento do indivíduo comum. O grupo tornase reflexivo e coloca-se como grupo. Feito o juramento, o grupo passa para outro momento, que é o da sua organização. No momento da organização, o grupo se trabalha, faz-se grupo e só se mantém grupo, na medida em que se faz continuadamente. O grupo só age no objeto externo a ele, na medida em que age sobre si mesmo. Essa ação sobre si mesma é a única que o grupo 
exerce como grupo e resume-se em o grupo definir, dirigir, controlar e corrigir, sem cessar, a práxis comum (LAPASSADE, 1977).

Desse modo, o processo de organização do grupo pode ficar restrito ao estabelecimento de regras e condições, para impedir a sua dispersão, possibilitar o seu funcionamento e gerar um funcionamento paranoico. Submeter o grupo à observação é colocá-lo na condição de submeterse à avaliação de um terceiro, da ciência, de outras unidades de Saúde da Família, de outras pessoas e de outros pesquisadores. Em outras palavras, o grupo agora se vê em uma situação de ser julgado, da mesma forma que ele julga o próprio grupo.

Gonçalves (1994) também discutiu esse constrangimento causado nos profissionais, pela presença de um observador que registra ou documenta sua atividade, e que pode bloquear o desenvolvimento das atividades ou que leva à falsificação dos procedimentos, em referência aos que são habitualmente realizados. Quanto à primeira consequência, Gonçalves (1994) relatou que o constrangimento foi rapidamente disperso, fazendo com que os profissionais voltassem a realizar suas atividades de forma natural, o que também foi observado no caso deste estudo. Com relação à segunda consequência, Gonçalves (1994) não considera que seja possível a substituição completa de uma tecnologia de trabalho por outra, mas que poderia haver uma falsificação quando se procede na direção do que concebem como melhor, o que intensifica as concepções a respeito do objeto de trabalho, suas finalidades e suas articulações. Nesse caso, Gonçalves (1994) considerou essa substituição positiva, uma vez que se trata de um viés a favor da técnica e das hipóteses e não contra ela. A falsificação seria no sentido de procederem na direção do que concebem como melhor, o que intensifica as concepções a respeito do objeto de trabalho, suas finalidades e suas articulações.

Com a finalidade de atenuar esta reação à observação, foi retomado com os trabalhadores da equipe da USF Rubi o caráter confidencial das informações obtidas e o sigilo quanto aos nomes das pessoas participantes as quais também estavam expressas no Termo de Consentimento Livre e Esclarecido. Aos poucos, o gravador foi esquecido, e o grupo voltou ao comportamento natural.

Nessas reuniões houve um encontro entre os atores sociais das práticas de saúde da USF Rubi, local onde ocorrem agenciamentos, onde se processam modos de subjetivações e objetivações que são necessários para novidades produtivas. O inconsciente é produzido em cada agenciamento e em cada dispositivo que se autogera para originar um acontecimento e um sentido (BAREMBLITT, 2002). 
Os analisadores, conforme foi explicado na metodologia deste estudo, podem ser qualquer materialidade, discursos, monumentos estatutos, ou seja, é um fenômeno que já possui nele, elementos para se autoentender, para começar o processo de autoesclarecimento (BAREMBLITT, 2002). Podem ser analisadores históricos, que são fenômenos dados na trajetória de vida de forma histórico-social, determinada pela objetividade, subjetividade do homem em relação ao seu cotidiano, assim como a forma com que o homem se relaciona, na sociedade, com outros homens e com as coisas materiais. E podem ser analisadores superficiais, ou seja, dispositivos construídos e que são introduzidos nas organizações para propiciar o processo de explicitação dos conflitos e de resolução dos mesmos.

Durante a produção dos dados, entre as reuniões administrativas e reuniões de discussões de casos de família, foram percebidos dois analisadores históricos, ou seja, que não foram produzidos artificialmente, mas que foram localizados na trajetória da equipe, respeitando os seus processos e seus desejos, ou seja, localizados a partir das próprias necessidades da equipe: A organização da agenda da Saúde Bucal; A equipe e uma de suas Famílias: o caso da família do Sabiá Laranjeira. Também foi produzido um analisador artificial acerca de uma intervenção possível junto à equipe sobre Saúde Bucal, com o intuito de discutir a inserção da Saúde Bucal no processo de trabalho da equipe.

\subsubsection{Revendo a agenda da Saúde Bucal da equipe da USF Rubi}

Para introduzir o assunto, foi ofertado à equipe discutir a respeito de temas mais específicos da organização das portas de entrada para a Saúde Bucal na USF Rubi e que acabaram gerando a demanda por outros temas que estão relacionados à organização da Atenção em Saúde Bucal para os usuários da unidade, tais como, as portas de entrada e acesso ao atendimento odontológico, as urgências a pacientes eventuais, tratamento cirúrgicorestaurador, preventivo e de promoção à saúde, e a construção da interdisciplinaridade no processo de trabalho na equipe de Saúde da Família.

As discussões, a respeito da organização da Saúde Bucal na USF Rubi, foram previamente inseridas na pauta da reunião administrativa. As discussões foram iniciadas com uma breve explicação do assunto e um convite à equipe no sentido de avaliar as ações de Saúde Bucal desenvolvidas e de compartilhar a construção de novas práticas que proporcionassem melhor desempenho da área. 
Cabe ressaltar que a intencionalidade dos pesquisadores era mobilizar a equipe para caminhar por um processo de autoanálise e autogestão.

A inserção desses temas relacionados à Saúde Bucal na reunião administrativa remeteu à seguinte pergunta aos pesquisadores: a equipe reconheceria estes temas como objeto de seu processo de trabalho?

Essa inquietação se justifica por considerarmos a equipe um grupo organizado e detentor de um estatuto de permanência no grupo, o juramento do grupo. Isto faz com que o grupo seja seu objetivo imediato, se toma sempre e primeiramente como objetivo. Em outras palavras, ele se trabalha para poder trabalhar, procurar objetivos comuns (LAPASSADE, 1977). Portanto, o acolhimento dessa discussão pela equipe estava relacionado ao reconhecimento das ações da Saúde Bucal como um dos seus objetivos comuns.

$\mathrm{Na}$ primeira dessas reuniões, a pauta foi sobre a possibilidade de ampliar a consulta de Saúde Bucal na USF Rubi para dois períodos e, na UBDS, para três períodos de atendimento odontológico; ao mesmo tempo em que convidava a equipe para avaliar a organização, o grupo e a consulta de Saúde Bucal bem como a necessidade de criar vaga para o atendimento de eventuais com relação à Saúde Bucal. A proposta de ampliação foi motivada pela solicitação da equipe em oferecer atendimento em Saúde Bucal no período da tarde e a reivindicação dos alunos quanto ao atendimento cirúrgico-restaurador.

[...] CD Buriti: A ideia é a gente conversar um pouco sobre o atendimento odontológico, que eu sei que a DO Hibisco já adiantou para vocês que a gente tem a possibilidade e também a vontade de estar estendendo um pouco, aumentando o ritmo de atendimento aqui e o ritmo de atendimento lá na UBDS. Mas, também, eu gostaria de ver com vocês como é que está a organização, a questão do grupo, das consultas [...] só pra que a gente pudesse repensar essa organização, pra ver se está legal, se deve mudar alguma coisa, se a gente deve reservar horário para consultas eventuais aqui também. (Reunião Administrativa - 05/02/2010)

Embora a fala seja no sentido de uma conversa sobre a área de Saúde Bucal, o intuito era de promover "discussão" acerca do sentido e do significado desta palavra - "discussão" - no dicionário Aurélio de Língua Portuguesa (FERREIRA, 2010), ou seja, o debate, a controvérsia, a polêmica, o que muitas vezes gera um processo árduo e sofrível. Porém, Lapassade (1977), ao discutir processos grupais, diz que as discussões são indispensáveis, e que podem manifestar em determinado momento, uma virulência, sendo este o momento em que se colocam todas as formas e complexidades do objeto em discussão.

O segundo momento de discussão sobre a Saúde Bucal foi pautado seis meses depois, em decorrência da implantação das propostas sugeridas na primeira reunião. Para a existência deste intervalo de tempo, também contribuíram as demandas da equipe com relação ao seu 
processo de trabalho, embora assuntos relacionados à Saúde Bucal tenham surgido nas reuniões, mas de forma pontual.

Nessa ocasião, propôs-se novamente repensar a organização da Saúde Bucal, contextualizando a função do grupo para a unidade e para a Saúde Bucal desde a implantação da USF Rubi. Em seguida, foi introduzido um dado novo para discussão, quer seja, o número reduzido de usuários participantes do grupo de Saúde Bucal nos últimos meses.

[...] CD Buriti: Então para a gente poder lembrar um pouco, lá atrás quando começou o Núcleo, a gente propôs de começar todos os atendimentos com o grupo, que era uma reunião em que os pacientes vinham, cujo objetivo era explicar como funcionava o atendimento, estimular a discussão de alguns problemas de Saúde Bucal, fazer um contrato de convivência. E naquela época era muito interessante, porque a maioria dos pacientes estava vindo pela primeira vez e não sabiam o que era a Estratégia de Saúde da Família, nem como que poderia ser o atendimento odontológico dentro desta proposta de atendimento, do PSF. Bom, foi bastante interessante, isto ficou durante alguns anos e o que a gente tem visto, recentemente, é que este grupo está se esvaziando. De uma certa forma, alguns pacientes têm retornado para um novo ciclo de atendimento, é o segundo, terceiro ou quarto ciclo de atendimento, que é uma coisa interessante. Isto é importante. Os problemas de Saúde Bucal não são problemas que se resolvem de uma vez só, exigem continuidade de avaliação, de acompanhamento, demonstra até um certo vínculo, adesão ao tratamento. Mas a gente tem percebido também que tem tido um esvaziamento dos grupos. Então, uma coisa para ser discutido é isso, é a questão dos grupos, como que é? Como que vocês estão vendo? Será que é interessante mudar, fazer de uma forma diferente, uma forma diferente de estar trabalhando com a população da área do USF Rubi? E aí também surgiram algumas dúvidas com relação ao agendamento, o que agendar, o que não agendar. Então, eu acho que seria um momento interessante da gente estar revendo isso. (Reunião Administrativa 20/8/2011)

Nessa proposição para discussão de temas de Saúde Bucal foi relembrado o início das atividades da USF Rubi, um momento em que houve um empenho de toda a equipe no sentido de firmar o seu processo de trabalho, segundo as diretrizes do Programa de Saúde da Família (PSF), tendo como referência os Cadernos de Atenção Básica do Ministério da Saúde (BRASIL, 2000b) e criar uma identidade junto à população adstrita da USF. Uma das diretrizes que a diferencia das unidades convencionais de saúde acabou sendo tomada como uma das prioridades do seu processo de trabalho (BRASIL, 2000b). Trata-se de priorizar ações de identificação dos problemas de saúde e elaboração de práticas coletivas. Uma destas práticas são os grupos que podem ter a conotação de promover a saúde ou de monitorar doenças/agravos de diferentes naturezas. Também fazia parte desta estratégia a assistência integral prestada por meio de consultas periódicas, visando ao rastreamento de doenças em homens e em mulheres (SANTOS, 2010).

A prática de atenção à Saúde Bucal inseriu-se no contexto dessas diretrizes, uma vez que as portas de entrada se davam por um grupo, seguido por consultas de Saúde Bucal e atendimento cirúrgico-restaurador Os pacientes que apresentavam uma necessidade mais premente tinham os seus agendamentos antecipados, visando ao atendimento cirúrgicorestaurador e, para os casos de urgência, havia a disponibilidade de atendimento imediato na 
UBDS. Paralelamente, continuavam seu seguimento nas consultas de Saúde Bucal na USF. A inserção dos usuários para atenção à Saúde Bucal por meio do grupo e das consultas foi um dispositivo criado para concretamente valorizar as medidas de controle das doenças bucais e as ações de prevenção e promoção da saúde, sem descuidar da dimensão da recuperação da Saúde Bucal.

Porém, para a população, tratava-se de algo bastante inusitado, pelo menos naquele local, uma vez que havia uma proposta de acompanhamento odontológico sem equipamentos na USF Rubi. Assim, tornava-se necessário informar os usuários a respeito das mudanças da oferta de serviços e, principalmente, defender junto à população que a intenção das USFs estava para além de atender os doentes, mas não deixá-los adoecer e nem perder seus dentes, melhorando a qualidade da convivência com as doenças crônicas.

Nesse contexto de formação da USF, havia duas intencionalidades presentes no processo de trabalho da Saúde Bucal que se colocavam. Uma delas voltada para compor com a equipe, o processo de trabalho da unidade, e outra, no sentido de valorizar as tecnologias leves e leveduras (MERHY; ONOKO, 2002) no processo de trabalho da Saúde Bucal.

A literatura traz que o desejo de praticar o cuidado em Saúde Bucal, que vai além do cirúrgico-restaurador, também é compartilhado por dentistas e alunos de cursos de odontologia, assim como o relato de estranhamento por parte da equipe e da população com relação à atenção em Saúde Bucal (TEIXEIRA, 2006; REIBNITZ JÚNIOR; CAETANO; PRADO, 2009; GONÇALVES; RAMOS, 2010).

Nessa reunião, a discussão ocorre em torno do atendimento eventual, da urgência odontológica, da especificidade da odontologia e de problemas gerados na unidade em função da falta de informações a respeito de sua organização. A equipe mantém a atividade de grupo e pede a elaboração de critérios para a recepção de pacientes com necessidades de atenção em Saúde Bucal, um instrumento para ser manejado por toda a equipe.

No terceiro momento de discussão, são apresentados os critérios para recepção de pacientes que procuram o atendimento odontológico na USF Rubi e convida-se a equipe a pensar a Saúde Bucal como uma disciplina pouca conhecida pela equipe (Apêndice 3).

Inicialmente, o CD Buriti informou sobre a organização da nova agenda, as datas e a organização dos grupos de odonto. Discute-se um pouco sobre os exames radiográficos e retorna para os agendamentos, quanto ao número de usuários/famílias agendadas no grupo, grupos para o restante de 2010, férias dos alunos e do dentista. Em seguida, o dentista entrega para cada membro participante da reunião um diagrama com portas de entrada e tipos de paciente e uma definição de "problema". Lê inicialmente a definição, com o intuito de abrir a discussão da Saúde Bucal como um problema e algo ainda não bem conhecido pela Equipe. Em seguida apresenta-se a equipe as condições em que os usuários podem procurar o serviço, as alternativas de portas de entrada que são oferecidos e convida a equipe a pensar sobre a sua organização. Explora-se a condição do "paciente cordeiro", ressaltando o fato do paciente vir 
para marcar um horário para atendimento odontológico, ter um agravo de Saúde Bucal que necessite de atendimento urgente e não expressar a sua necessidade, levando-o a simplesmente seguir o fluxo. (Reunião Administrativa 03/09/2010)

A oferta para a equipe era a construção coletiva de um instrumento de trabalho, referente ao acolhimento do usuário que procura a atenção à Saúde Bucal. Para tanto era necessário desencadear uma discussão que propiciasse a troca de saberes e práticas de Saúde Bucal entre os profissionais da equipe, a ponto de possibilitar a abordagem do indivíduo de forma holística, por meio da ampliação do conhecimento sobre a área tornando a atenção à Saúde Bucal objeto das práticas de saúde da equipe, o que corresponde às recomendações das Diretrizes Nacionais de Saúde Bucal (BRASIL, 2004).

Durante essa reunião, foram apresentados e discutidos os critérios para recepção e orientação dos pacientes, mas não houve clareza do seu entendimento. Várias sugestões são apontadas e pauta-se a conclusão da organização da agenda para atendimento odontológico em outro momento.

Na sequência, é apresentada uma sugestão de um impresso específico como agenda para o ano de 2011, além de critérios para recepção e acolhimento dos pacientes.

Retoma-se a discussão da Saúde Bucal, lembrando que havia uma tarefa sobre a organização da agenda e inicia-se com uma síntese da reunião passada. Em seguida distribuiu-se para a equipe os critérios para agendamento/orientação dos pacientes e a agenda composta por impressos destinados à inscrição ao grupo e agendamento em 2011. Explica-se o objetivo dos impressos e são lidas as orientações para os pacientes, segundo a porta de entrada e os tipos de pacientes. (Reunião Administrativa 12/11/2011)

Esse movimento de pautar a discussão a respeito da atenção à Saúde Bucal, a partir das ofertas apresentadas pelos pesquisadores à equipe, a mobilizou na direção de apresentar as suas demandas, demonstrando que esta prática de saúde é um dos objetivos comuns da equipe.

Os dados produzidos nesses quatro momentos de discussão sobre a organização da agenda possibilitaram uma reflexão a respeito das instituições presentes na arena de uma equipe de Saúde da Família e que acabam gerando tensões na equipe em torno de uma prática assistencial, centrada na recuperação da saúde e pouco voltada para práticas coletivas de atenção à saúde. 


\subsubsection{A equipe e uma de suas famílias: o caso da família do Sabiá Laranjeira}

No início deste estudo também nos deparamos com uma das famílias da área de referência da USF Rubi, que por sua complexidade e capacidade de mobilizar a equipe, a tomamos como analisador, considerando mais especificamente a trajetória desta família, enquanto processo de compreensão do processo saúde-doença e planejamento de ações de cuidado por parte da equipe, no período de coleta de dados deste estudo.

Essa família que já havia sido apresentada nas discussões de caso de família na equipe da USF Rubi, trazida na maioria das vezes pelo ACS da microárea e abordada em outras nove reuniões de discussão de casos no período desta pesquisa. Foi possível perceber que no seu trajeto houve fases distintas de sua abordagem por parte da equipe, iniciando como certa resistência desta em abordá-la, num segundo momento com uma ação voltada para medicalização e institucionalização, em outro momento, com ações voltadas à construção da cidadania e de projeto de vida e, finalmente, a constatação dos limites que as circunstâncias que envolviam a família determinavam para os projetos terapêuticos discutidos e propostos.

Trata-se de uma família composta por três sujeitos, um pai, chamado Senhor Curió e seus dois filhos, uma menina de 18 anos, chamada Andorinha e um menino de 17 anos cujo nome é Sabiá Laranjeira. O encontro com esta família teve duas vertentes. Uma delas foi a demanda para o serviço de urgência odontológica da UBDS Citrino do Sabiá Laranjeira que, embora apresentasse uma necessidade premente de atendimento, não foi possível de ser realizada.

CD Buriti relata que o Sabiá estava sozinho no serviço de urgência e disse que queria tratar seu dente. O
dentista procura identificá-lo para realizar o atendimento e pede o cartão da unidade ou algum documento
de identidade e Sabiá está sem documentos pessoais. Pergunta-se a idade ao Sabiá, que responde 12 anos.
Verifica-se que a situação do dente fraturado não causa dor e que a intervenção irá requerer radiografia,
anestesia e intervenção endodôntica, sendo necessária a presença de um responsável para acompanhar o
atendimento do Sabiá. Então, o Sabiá é orientado a retornar com seu pai ou responsável para ser possível o
tratamento e localiza-se sua moradia com relação as áreas de referência das unidades de Saúde da Família,
constatando que Sabiá pertencia à unidade de Saúde de Família Rubi (Atendimento de Urgência - UBDS
CITRINO - 03/02/2011).

Nesse acolhimento pelo serviço de urgência chamaram a atenção os fatos que Sabiá não portava documentos pessoais nem mesmo o cartão de identificação de qualquer unidade de saúde, dizia ter 12 anos e aparentava ter mais idade, adicionalmente foi necessário repetir a mesma informação a respeito da necessidade de estar acompanhado por um responsável para realizar seu atendimento. Diante da situação de um problema odontológico que poderia evoluir para a dor a qualquer momento e que o prejudicava esteticamente, o CD Buriti levou o caso 
para ser discutido junto à equipe da USF Rubi, unidade de referência assistencial para a família do Sabiá Laranjeira.

A abordagem desta família, na discussão de caso de família em virtude do acolhimento da urgência do Sabiá, gerou outra vertente deste encontro que foi a necessidade da ACS Nogueira mobilizar a equipe para discuti-la.

\begin{abstract}
A ACS Nogueira disse na reunião de discussão de casos de família que está muito preocupada com um membro da família i, micro área s. É uma família composta por três pessoas, um pai, Sr Curió, uma filha, a Andorinha, de dezoito anos que tem uma deficiência mental e o Sabiá, de dezessete anos, que tem uma defasagem de aprendizagem, talvez, algum distúrbio mental, mas não tem nenhum diagnóstico. A defasagem de aprendizagem é bem visível e ele tem atitudes de uma criança de doze anos. A ACS Nogueira foi procurada por este menino, que pediu para ser atendido pelo dentista do USF Rubi, por ter um dente da frente, com a coroa fraturada. A ACS Nogueira o orientou a procurar o serviço de urgência, que é específico para resolver essa questão pontual e de fácil acesso e procurar o atendimento odontológico. Então, disse a ACS Nogueira, que o Sabiá, passou a semana toda na unidade, ele foi nessa segunda, na terça, procurando atendimento e que já tinha orientado tanto a ele quanto ao seu pai a procurar o serviço, por que o Sabiá não tinha dezoito anos e ele precisa que alguém, um adulto, uma pessoa com mais de dezoito anos seja responsável por ele durante o atendimento, para autorizar os procedimentos que seriam necessários. Então, o CD Buriti relatou o acolhimento realizado no serviço de urgência e percebi que havia percebido que era mesmo um incisivo central que tinha uma coroa fraturada, uma fratura de aproximadamente metade do dente, metade da coroa, visível, e havia um escurecimento dessa coroa e provavelmente, isso iria levar a uma intervenção endodôntica e seria importante que o pai autorizasse esse procedimento e o acompanhasse. Disse que esta situação foi explicada ao Sabiá três vezes, e nas três vezes nós começamos falando do mesmo ponto, ou seja, "olha seu pai não veio, precisa de alguém vir te acompanhar", e ele respondia como se ele tivesse chagado naquele momento no serviço sem saber por que o pai tinha que vir. Foi pedido o telefone do pai para que se entrasse em contato e ele disse que o pai não estava em casa e não tinha como entrar em contato. A ACS Nogueira, disse que nas três vezes que ele esteve na USF Rubi foi da mesma forma, que ela repetiu a mesma conversa, partindo-se do mesmo ponto de um pedido de uma solicitação pra resolver o problema do dente anterior e que o Sabiá Laranjeira foi ao serviço de urgência, provavelmente, por conta própria, o que é um risco também, porque uma criança que tem essa defasagem de aprendizagem andando na rua a noite ela está se expondo a um risco de tráfico e de outros perigos. Foi dito pela equipe que o $\mathrm{Sr}$ Curió parece que faz na medida do possível o que pode para cuidar da casa e dos dois filhos, mas que ele se sente muito cansado, às vezes até deprimido, tanto que segundo a MD Acácia, passou a fazer uso de antidepressivo, e que ele precisa de um certo apoio da equipe. No final, ficou acertado que a ACS Nogueira iria entrar em contato com o Sr. Curió, para que o Sabiá retornasse na sexta-feira para fazer o atendimento de urgência na UBDS Citrino, acompanhada pelo pai. (Reunião de Discussão de Casos de Família, 04/02/2011)
\end{abstract}

Percebemos que não houve sensibilização para uma construção conjunta no sentido de evidenciar os problemas de saúde desta família, das dificuldades do pai em cuidar das crianças e de uma estratégia para inserir o pai no tratamento odontológico dos filhos bem como no acompanhamento de saúde.

Nas discussões de família em que essa família voltou a ser abordada, foi percebido um envolvimento gradual dos profissionais, onde inicialmente o aprimorando em psicologia se dispôs a verificar a situação da Andorinha e do Sabiá na CADE e que resultou em informações, mas também possibilitou a reintegração da Andorinha na CADE, possibilidades de encaminhamentos para o Sabiá e acompanhamento psiquiátrico para o Sr. Curió. A terapia ocupacional, por meio dos alunos, supervisores e docentes acompanharam esta família, 
especificamente realizando terapia com o Sabiá no sentido da construção de projeto de vida e estímulo ao desenvolvimento de sua autonomia, ainda criou uma relação de trabalho multiprofissional e interdisciplinar com a Saúde Bucal e contribuiu com a equipe para uma ampliação do entendimento acerca da família, quanto aos seus limites, situação de risco para a Andorinha e o Sabiá, o que possibilitou estruturar os possíveis encaminhamentos junto a esta família.

\subsubsection{Discutindo a Saúde Bucal com a equipe da USF Rubi}

No desenvolvimento da investigação, foi proposto para a equipe da USF Rubi utilizar o horário de Educação Permanente com o objetivo de proporcionar uma atividade relacionada à Saúde Bucal junto à equipe. A proposta dos pesquisadores era mobilizar a equipe para discutir o seu processo de trabalho com relação à Saúde Bucal, e foi desenvolvida pelo pesquisador, contando com as observações da atividade pela coorientadora deste estudo. Para a equipe, foi feito um convite para discutir questões de Saúde Bucal na Estratégia Saúde da Família. Foi planejada uma dinâmica para aquecimento dos participantes com bexigas e para iniciar a discussão foram utilizadas frases das Diretrizes da Política Nacional de Saúde Bucal (BRASIL, 2004), referentes ao Processo de Trabalho em Saúde Bucal, a saber:

- A atuação dos serviços de saúde não deve se limitar exclusivamente ao campo biológico ou ao trabalho técnico;

- Nos serviços de saúde, deve haver interação com profissionais de outras áreas, de forma a ampliar seu conhecimento;

- A troca de saberes e o respeito mútuo às diferentes percepções devem acontecer permanentemente entre todos os profissionais de saúde;

- O profissional deve ser, e se sentir, parte da equipe multiprofissional em unidades de saúde de qualquer nível de atenção;

- A equipe deve estar capacitada a oferecer de forma conjunta ações de promoção, proteção, prevenção, tratamento, cura e reabilitação, tanto no nível individual quanto coletivo;

- As ações de promoção de saúde são mais efetivas se a escola, o local de trabalho, o comércio, a mídia, a indústria, o governo, as organizações não governamentais e outras instituições estiverem envolvidas; 
- A intersetorialidade implica envolver no planejamento os diferentes setores que influem na saúde humana: entre outros a educação, agricultura, comunicação, tecnologia, esportes, saneamento, trabalho, meio ambiente, cultura e assistência social;

- O conceito ampliado de saúde deve nortear a mudança progressiva dos serviços, evoluindo de um modelo assistencial centrado na doença e baseado no atendimento a quem procura, para um modelo de atenção integral à saúde, onde haja a incorporação progressiva de ações de promoção e de proteção, ao lado daquelas propriamente ditas de recuperação.

Era 7:30h e inicialmente consultamos os profissionais da USF Rubi que já estavam na sala de reuniões sobre a possibilidade de realizarmos a reunião na parte de baixo do prédio em função do espaço ser maior. Todos concordaram. Rapidamente todos se dirigiram para este espaço e logo iniciamos a atividade. Inicialmente, pedi para colocarem um papel enrolado dentro das bexigas e após enchê-la. Todos cooperaram e rapidamente todas as bexigas estavam cheias. Em seguida convidamos para a segunda atividade convidando-os a imaginar as bexigas como o nosso trabalho, nossas atividades, nossa família, as boas coisas da vida e pedi para que começássemos a jogar a bexiga e cuidar para que não caíssem no chão. Todos participaram de uma forma colaborativa. Apenas uma bexiga estourou. Após alguns minutos de atividade, pedi para diminuirmos aos poucos os movimentos e interrompemos a atividade. Convidei-os a sentarem. Quando todos já estavam acomodados, pedi para estourassem as suas bexigas. Como alguns estavam com dificuldades, procurei ajudá-los com um estilete. Em seguida orientei sobre a próxima atividade, dizendo que aquele papel dentro da bexiga podia possuir uma frase para ser comentada ou um conjunto de símbolos. Para os que saíram com as frases, foi pedido para comentarem se viviam aquilo ou não, para exemplificar com uma situação ou comentar as dificuldades. E para os que saíram com os símbolos, trocariam de lugar com o colega que quisessem. A primeira a responder foi MD Acácia. (Reunião sobre Saúde Bucal, 08/02/2011)

Após as falas a respeito de cada proposta das Diretrizes, foi apresentada à equipe a referência do material discutido, entregue a todos os membros uma cópia das Diretrizes Nacionais de Saúde Bucal (BRASIL, 2004) referente ao Processo de Trabalho das Equipes de Saúde Bucal. A seguir foram lidos e comentados os conceitos relacionados à discussão, e a reunião foi encerrada às $8 \mathrm{~h} 46 \mathrm{~min}$.

Da discussão foi possível agrupar as falas em temas relacionados ao processo de trabalho em equipe e à Saúde Bucal e possibilitou compreender melhor as questões relacionadas à inserção da Saúde Bucal na USF Rubi, com relação à tensão entre as ações de recuperação, prevenção e promoção à saúde, o trabalho interdisciplinar e as instituições presentes nesta arena. 


\section{CARTOGRAFANDO A EQUIPE DA USF RUBI}

Compartilhando as atividades cotidianas da USF Rubi, os pesquisadores reconheceram dois contextos do trabalho da equipe, que foram considerados analisadores para este estudo, uma vez que eram produtos do próprio processo de trabalho da equipe e mostravam-se potentes para produzir conhecimento sobre a inserção da Saúde Bucal na Estratégia Saúde da Família. Também foi produzido um analisador artificial, uma das últimas atividades na produção de dados e que teve o objetivo de discutir mais profundamente questões do objeto deste estudo.

Os analisadores histórico-sociais foram: Revendo a agenda da Saúde Bucal da equipe de Saúde da Família Rubi e a Família do Sabiá Laranjeira, que já faziam parte do trabalho da equipe, foram objeto de trabalho no período de produção dos dados deste estudo e continuam em pauta na dinâmica de trabalho da USF Rubi. Trata-se de momentos de trabalho da equipe, de reuniões da equipe, em que se discutiram estas questões e produziu-se conhecimento, provisório, verdadeiro para aquele momento e que o devir da equipe, pode levá-la a outras verdades, sem que haja expectativa por parte destes pesquisadores, que seja melhor ou pior, apenas gerando novos processos, construindo a sua história.

$\mathrm{O}$ analisador artificial foi uma intervenção, onde os pesquisadores se propuseram a discutir com a equipe da USF Rubi a inserção da Saúde Bucal na unidade, possibilitando discutir questões centrais deste estudo, como o trabalho em equipe, a interdisciplinaridade, as relações na equipe e a saúde bucal.

Vivenciar em equipe estes analisadores possibilitaram cartografar os movimentos da equipe no sentido dos limites e as potencialidades para construção de práticas de Saúde Bucal na Estratégia Saúde da Família. A cartografia possibilitou identificar eixos que são transversais aos analisadores, ou seja, estão presentes nas discussões dos três analisadores, mostrando-se potentes para realizar uma leitura dos processos que vivenciamos. Os eixos transversais aos analisadores são:

- Relações estabelecidas entre os atores disciplinares;

- A assistência, atenção e a clínica ampliada na Equipe da USF Rubi;

- Alienação no processo de produção de cuidado em saúde pelo USF H.

- A Saúde Bucal na arena da atenção básica em saúde e da Estratégia Saúde da Família. 


\subsection{Relações estabelecidas entre os atores disciplinares}

Logo no início da coleta de dados, podemos perceber uma disposição dos profissionais da equipe da USF Rubi em discutir questões da Saúde Bucal na reunião administrativa em função da dinâmica do próprio trabalho, sendo que a organização da agenda era uma das demandas da equipe. Parte desta disposição pode ter sido influenciada pela expectativa dos profissionais quanto à pesquisa. Também, percebe-se uma carência de informações por parte dos profissionais não dentistas a respeito do funcionamento da área de Saúde Bucal, tornandose um processo de (re)conhecer as ações da área. Foi necessário informar, em diversos momentos, as rotinas e as propostas da área. Esse processo resultou em novos posicionamentos acerca dessas ações.

[...] DO Cerejeira: CD Buriti, eu não estou entendendo uma coisa. DO Hibisco, aqui ele (CD Buriti) faz tudo isso que você falou, anamnese, evidenciação de placa, tudo é feito em conjunto, todo mundo ao mesmo tempo?

[...] ACS Ébano: já que a gente está esclarecendo dúvida, deixa eu colocar, por exemplo, a pessoa está com dor, ele pode procurar o próprio atendimento na UBDS o dia todo?

[...] MD Acácia: Talvez não esteja claro para a população e nem para a gente este seguimento odontológico, esteja claro quando é pressão alta, quando é diabetes, mas quando é boca, às vezes não é uma coisa clara para todo mundo. (Reunião Administrativa 20/8/2011)

O pouco conhecimento a respeito da Saúde Bucal por parte da equipe pode ser um dos motivos que levam a mesma a não se sensibilizar em reconhecer os problemas de Saúde Bucal dos usuários, conforme aconteceu com o Sabiá Laranjeira. Na primeira reunião de discussão de casos de família da equipe da USF Rubi que compõe o conjunto de análises realizadas neste estudo, o dentista informa à equipe sobre a procura pelo atendimento de urgência odontológica pelo Sabiá, com a expectativa de conhecer melhor a família e construir com a equipe uma estratégia para viabilizar o seu tratamento. A equipe colabora na compreensão dos problemas da família, mas não foi possível perceber a dimensão de um dos dentes anteriores fraturado para um adolescente que estava começando a conhecer a vida.

Essa carência de conhecimento pode estar relacionada com a não responsabilização por parte dos profissionais da equipe com os problemas de Saúde Bucal dos usuários da unidade. Por outro lado, a ACS Nogueira, quando procurada pelo Sabiá Laranjeira, em razão 
de uma demanda que necessitava de atendimento imediato, soube buscar a informação e orientá-lo quanto ao horário do atendimento e à necessidade de estar acompanhado por responsável, denotando responsabilização com o usuário.

Para outros profissionais da equipe da USF Rubi, o trabalho em equipe se dá por explicações das condutas tomadas ou discussão de casos esporádicos.

[...] RMFC Louveira: a frase "Nos serviços de saúde deve haver interação com profissionais de outras áreas de forma a ampliar o seu conhecimento" [...] é com esse sentido mesmo que eu vi ações na USF Rubi, que você vive uma questão, que tem um profissional específico para aquela área, para te ajudar, vai te explicar o porquê ele tem aquela decisão ou aquela conduta.

CD Buriti: você vive isto aqui ou já viveu isto em algum lugar.

RMFC Louveira: assim não, por que aqui além de ter um profissional dentro do espaço físico, de onde a gente está, você tem que ter esta relação mesmo com ele, muitas vezes ele está no consultório, você no seu e acaba não saindo nenhuma conversa.

CD Buriti: você tem um caso para nos contar, "um causo", para nos contar?

RMFC Louveira: durante a graduação fiquei também em um programa de saúde da família, só que o dentista ia lá e a gente nem via, e a gente não mantinha uma conversa, precisa de aconselhamento, câncer bucal, discutir um caso e não tinha, cada um com o seu horário, era separado e aqui há mais interação mesmo. (Reunião sobre Saúde Bucal, 08/02/2011)

O desconhecimento das ações de Saúde Bucal, ou a não responsabilização por parte dos profissionais, também nos remete à condição da ausência de interação e articulação entre as disciplinas de odontologia e de Saúde Bucal com outras da saúde presentes no processo de trabalho da equipe USF Rubi, o que pode caracterizar uma ausência de relações entre disciplinas ou uma atuação de forma multidisciplinar. Nessa forma de interação entre saberes e práticas, os profissionais tratam de uma mesma questão, assunto ou problema simultaneamente, tendo o mesmo objeto de trabalho, mas sem que os profissionais implicados estabeleçam entre si uma relação técnica e científica. Caracteriza-se pela condição de haver um agrupamento de disciplinas, uma justaposição, mas que mantém um isolamento disciplinar, configurando a construção de um sistema disciplinar de apenas um nível e com diversos objetivos (JAPIASSU, 1976; ALMEIDA FILHO, 1997).

Erdmann, Schlindwein e Souza (2006) afirmam que a saúde tem mais recentemente uma trajetória centrada na vida dos cidadãos e em função disto, poderá encontrar nas práticas interdisciplinares um espaço privilegiado para repensar teorias e práticas, inovando as formas de pensar a saúde, a doença e a prestação de serviços. 
Desse modo, se faz necessário o diálogo entre diferentes saberes na saúde, no sentido da produção de conhecimento, a ponto de desenvolver um tipo de interdisciplinaridade, ou seja, uma relação entre disciplinas, em função da prática dos atores sociais em religarem os saberes. Esta construção das interações entre as disciplinas no campo da teoria e da prática da saúde espera-se que evolua da multidisciplinaridade para pluridisciplinaridade, interdisciplinaridade e transdisciplinaridade. A construção da interdisciplinaridade é um processo de avanços e retrocessos, de experimentações e construção coletiva, sendo que o conjunto de profissionais pode desenvolver, em momentos distintos, formas distintas de interação de seus saberes, conforme nos indica Coimbra (2002, p.293), por meio de uma alegoria coreográfica:

[...] Numa ação interdisciplinar as partes envolvidas dão-se as mãos, movimentam-se juntas como um balé, voltadas para o tema central. Aproximam-se, afastam-se; interpelam-se, respondem-se; ora se exibe o solista, ora se impõe o coro. O essencial da interdisciplinaridade consiste em produzir uma ação comum, mantendo cada participante o que lhe é próprio.

Coimbra (2002) poderia ter ido além em sua alegoria, uma vez que na produção da ação comum, cada participante pode manter o que lhe é próprio em uma relação interdisciplinar, ou todos os participantes se modificarem, como no caso da transdisciplinaridade.

Na vivência do acompanhamento da família do Sabiá Laranjeira, é possível localizar em um fragmento que, embora haja um movimento para o cuidado à família pela equipe, ainda há uma comunicação fragmentada entre seus membros. Existe certa resistência colocada no fato de o usuário ser considerado da responsabilidade de um dos membros da equipe, ou seja, não há um processo consolidado em que a equipe possa discutir a situação das famílias sob sua responsabilidade de tal forma que haja comunicação horizontal entre eles, por exemplo, traduzida na solicitação da ACS Nogueira para acompanhar a visita à CADE, ou na lembrança da MD Acácia que segue o pai dos adolescentes. Uma das hipóteses para explicar esta comunicação truncada é a tendência da equipe em discutir questões clínicas que envolvam aspectos técnicos e biológicos do cuidado, as quais seduzem pela falsa impressão das certezas disciplinares e da criação de uma zona de conforto.

[...] PS Macieira: é a família i, que vocês lembram que a MD Acácia passou, um pai com duas crianças, que possivelmente tem um retardo mental, e a menina estava indo na CADE só duas vezes por semana, então eu liguei na CADE para saber o que estava acontecendo, e a psicóloga de lá quis marcar uma reunião comigo para explicar o caso. Eu estarei marcando na semana que vem, possivelmente na segunda 
feira. Vamos ver o que a gente pode fazer para aumentar esta frequência dela na CADE, ver se isto vai ser possível. Estagiária da TO, você que ir comigo na CADE?

MD Acácia: é ela que atende o pai do Sabiá Laranjeira.

A ACS Nogueira: gostaria de acompanhar a visita.

PS Macieira: Pode ser, vamos junto. (Reunião de discussão de casos de família do dia 22/04/2010)

Podemos observar que, para parte dos profissionais, o trabalho em equipe voltado à troca de saberes e ao respeito mútuo entre os membros localiza-se na interação entre as pessoas.

[...] MD Acácia: o grande desafio de trabalhar em equipe é respeitar o outro e conseguir se colocar no lugar do outro, e que passa por isso todo dia.

ALN Pequi: é a maior vantagem trabalhar em equipe, é respeitar a opinião do outro, é você ver que tem outras maneiras de resolver os problemas, de atender, tem outras funções também, por exemplo, de repente eu não sou tão especialista no assunto, tem outro que é, é respeitar a opinião do outro ...

ALN Pêra: é aproveitar este conhecimento, a gente está pouco tempo aqui, eu nunca tinha participado de uma equipe multiprofissional, é uma novidade, espero que eu a gente saiba aproveitar, é uma coisa nova. (Reunião sobre Saúde Bucal, 08/02/2011)

Fortuna e Mishima9 (1998, apud FORTUNA, 1999, p. 22), ao pesquisarem as abordagens dos estudos com relação ao trabalho em equipe na saúde, encontraram três possibilidades. Em uma delas a abordagem se dá a partir dos resultados, onde a percepção da equipe está voltada para o aumento da produtividade do e no trabalho. Aqui ela é vista como insumo e não se consideram os seus conflitos. Outra é a partir das relações, que percebe a equipe a partir do olhar da psicologia, busca o aumento da eficiência, da eficácia e a analisa com o foco das relações interpessoais e processos psíquicos. E por último, a abordagem baseada na interdisciplinaridade, que a considera no contexto da discussão e articulação dos saberes, abrangendo também as discussões a respeito da divisão técnica e social do trabalho.

Essas três possibilidades da abordagem do trabalho em equipe apresentadas pelas autoras oferecem pistas sobre o tema. No entanto, compartilhamos da mesma perspectiva que

\footnotetext{
${ }^{9}$ FORTUNA, C. M.; MISHIMA, S. M. O trabalho em equipe em saúde: análise a partir de perspectivas teóricas. Ribeirão Preto, 1998. In: Colóquio Pan-Americano de Investigação em Enfermagem, 6., 1998, Ribeirão Preto.

Resumos... Ribeirão Preto, 1998. p. 296. Mimeografado.
} 
Fortuna (1999, p.23), ampliando essas três abordagens, ao atribuir ao trabalho em equipe o sentido de "um processo de inter-relação e pressupõe momentos de articulação e desarticulação, de entendimento e conflito, não se tratando de um status a ser alcançado, em que se tem dado ou não tem".

Assim, podemos dizer que, na vivência deste estudo, compartilhamos de uma das tensões da equipe a respeito de um dos seus objetivos de trabalho, no que se refere à assistência à saúde, de cunho orgânico e tecnicista ou à atenção à saúde, voltada para a defesa da vida.

\subsection{A assistência, a atenção e a clínica ampliada na equipe Rubi}

Logo no início da discussão a respeito da organização da agenda da Saúde Bucal na USF Rubi, foi apresentada outra demanda que se referia às ações de Saúde Bucal ofertadas aos usuários da unidade: o Grupo e a Consulta de Saúde Bucal.

Essa demanda também aparece na discussão sobre a Saúde Bucal, onde os profissionais da USF Rubi expressaram dificuldade em ofertar os serviços diante da expectativa dos usuários quanto aos cuidados odontológicos específicos, restringindo a uma expectativa centrada no modelo convencional, onde prevalece o biológico e o técnico, levando a uma demanda exclusiva por ações cirúrgico-restauradoras.

[...] ACS Ébano: CD Buriti, sabe uma outra coisa ruim, o fato das pessoas não entenderem o que é uma imagem negativa, eles falam assim, é ir lá, só para conversar, eu quero é ser atendido, ir lá para a UBDS e ser atendido, a gente ouve isto de monte aí nas casas.[...] então você cria uma imagem negativa de, ah você vai lá só para conversar, está enrolando, eles criam esta imagem.

CD Buriti: a consulta, ela é importante. [...] Quando o paciente vai direto para a UBDS Citrino, está lá na cadeira, eu tenho que rever a anamnese, eu tenho que fazer ou rever a evidenciação de placa, e outras questões, dependendo do problema de Saúde Bucal que ele tem, só que eu vou fazer em uma cadeira odontológica. Que tem um gasto enorme.

ACS Ébano: Mas ele vai se sentir como se tivesse no tratamento mesmo. Por estar dentro de um consultório, na cadeira, como aqui não tem consultório, a pessoa sente...

RFI Jequitibá: Mas isso precisa começar a mudar, né, a questão da prevenção. (Reunião Administrativa 20/8/2011)

[...] EF Aroeira: as pessoas chegam aqui com esta demanda, espontânea, centrada na doença, é muito comum. A gente está na recepção, a pessoa chega lá e diz que está com dor de dente. A gente tem que explicar que estamos oferecendo um serviço que é diferente, que tem uma outra organização, que ela vai ser agendada, ... o atendimento vai ser discutido, a família vai ser agendada para atendimento 
individual. Aí, a pessoa diz, eu vim só para tratar, eu não vou vir no grupo. As pessoas estão centradas na doença e é um embate na inserção, por que eles só querem resolver, fazer o curativo, fazer, né. Se for uma emergência, tiver com dor, tem uma opção de ir pronto atendimento. E aí, elas perguntam a que horas que eu vou no pronto atendimento. Então, né, ela muda o foco e já não quer agendar aqui mais. Que hora que eu vou na UBDS Citrino? Tem equipamento odontológico aqui? O dentista vai conversar, né, então não faz tratamento, né. Então, é extremamente difícil por que as pessoas vêm com o modelo centrado da doença, né, outras formas de olhar, de cuidar. Como o dentista trabalha aqui se não tem sala de dentista. (Reunião sobre Saúde Bucal, 08/02/2011).

De imediato, observa-se a valorização do aparato tecnológico da odontologia pela equipe da USF Rubi, localizando no equipamento odontológico o local privilegiado para o trabalho do cirurgião-dentista, mesmo no desempenho das atividades educativas ou clínicocirúrgicas, gerando tensão na equipe.

A UBDS Citrino possuía um serviço de atendimento odontológico direcionado para a população residente na sua área básica, onde estão localizadas as cinco áreas de referência das USF. No ano em que foram ampliadas as USF para a área básica da UBDS, o serviço de odontologia encontrava-se na situação de ter uma das suas duas cadeiras odontológicas danificadas e sem qualquer possibilidade imediata de recuperação ou substituição, levando a um revezamento na utilização de um único equipamento entre dois dentistas no período da manhã e outros dois no período da tarde. Paralelamente, o serviço também percebia que com a criação das USF, a porta de entrada do sistema de saúde se deslocara da UBDS para as USF.

Assim, se reconheciam as USF como serviços de saúde da atenção básica que configuram porta de entrada para o SUS. Em função das discussões que o serviço de odontologia da UBDS fazia a respeito da sua organização, havia uma intencionalidade por parte dos seus dentistas de manter as ações cirúrgico-restauradoras nesta instância, o que já era incorporado pela população. Nessa reorganização, outra intenção era ampliar as ações de Saúde Bucal, implantando nas USF dispositivos que possibilitassem outra compreensão do processo saúde-doença-cuidado, contemplando a integralidade da atenção à saúde e possibilitando a construção coletiva de ações de saúde, o que não era possível ser realizado na UBDS Citrino pelas suas características de unidade de saúde de nível secundário.

Dessa forma, decidiu-se que cada dentista assumiria uma das USF, a partir de um sorteio das unidades entre os dentistas, sendo que cada um teria metade de sua jornada de trabalho, ou seja, 10 horas, destinada ao trabalho nas USF e a outra metade dedicada ao atendimento odontológico, ações cirúrgico-restauradoras, na UBDS Citrino. A porta de entrada para a atenção à Saúde Bucal era a USF de cada território e, simultaneamente ou após as ações preventivo-promocionais, era realizado agendamento na UBDS para a realização dos procedimentos de recuperação da Saúde Bucal. Desse modo, nos horários em que o CD estava 
no serviço de odontologia da UBDS, realizava-se o atendimento aos pacientes da USF que o dentista pertencia e de pacientes não agendados, mas com queixas de atendimento imediato, prioritariamente residentes no território da UBDS Citrino. Outro motivo para esta configuração de atendimento entre as USF e a UBDS foi o limitado espaço físico das unidades e dos escassos recursos financeiros disponibilizados para implantação destas.

Na USF Rubi optamos em criar dispositivos que permitissem ações com o foco na utilização de tecnologias leves e leve-duras, bem como na definição de espaços físicos e estratégias para a gestão e produção do cuidado, que objetivava a construção de intersubjetividade entre sujeitos presentes neste cenário. Estes dispositivos foram o Grupo e a Consulta de Saúde Bucal, a participação ativa nas reuniões de discussão de casos de família e administrativas, e nos eventos da unidade, tais como o Festival da Saúde e o Dia da Criança.

Para o dentista e para a USF Rubi, esta trajetória resultou em significados maiores do que mudanças de lugares e de horários, pois determinaram mudanças no processo de trabalho.

A assistência odontológica, que segundo Narvai (1992) refere-se ao conjunto de procedimentos clínico-cirúrgicos dirigidos a consumidores individuais que estejam doentes ou não, apresenta um processo de trabalho próprio, sendo possível reconhecer os elementos constituintes na produção do cuidado em saúde, quer sejam, a força de trabalho, o objeto e os instrumentos e meios para a produção.

Cabe ressaltar que o objeto não se apresenta em sua totalidade, como natural, mas contém, potencialmente, o produto resultante do processo de transformação efetivado pelo trabalho. Esta qualidade de produto não transparece por si mesmo, imediatamente, de modo que essa qualidade precisa ser evidenciada ativamente no objeto. Por consequência, o objeto de trabalho se apresenta com qualidades delimitadas pelo sujeito, não existindo por si só, mas recortado por um olhar que contém o projeto de transformação, com uma finalidade, virtualmente o produto do processo transformador. Esta qualidade inerente ao objeto e diretamente vinculada ao desejo de transformá-lo em algo é a intencionalidade do processo de trabalho, ou seja, o projeto prévio para alcançar o produto desejado que esteja, ainda, na mente do trabalhador. Diz respeito à direção e à perspectiva em que será realizada a transformação do objeto em produto (MENDES GONÇALVES, 1994; PEREIRA e LIMA, 2008).

Assim, ao tomarmos o objeto do processo de trabalho situado na perspectiva da assistência odontológica, temos a cavidade oral reconhecida como área morfológica de atuação do cirurgião-dentista, à qual direciona a sua prática e eventualmente está assistido pelo técnico e auxiliar de Saúde Bucal. O objeto é a matéria que vai ser transformada, aquilo 
onde incide a ação do trabalhador que, na assistência odontológica, refere-se às necessidades biológicas, ou seja, o dente, a gengiva, a mucosa ou, sinteticamente, os tecidos moles e duros da cavidade bucal e sua fisiologia.

Quanto aos instrumentos e meios de trabalho, que dizem respeito a tudo aquilo que é colocado entre o trabalhador e seu objeto a ser transformado e serve para dirigir sua atividade sobre este objeto, constituem-se nos aparelhos, instrumentos, materiais consumíveis, equipamentos, saberes específicos para a operação destes aparelhos, materiais e equipamentos.

Nesse contexto da assistência odontológica, deve-se ressaltar que, atualmente, a clínica cirúrgica-odontológica é reconhecida como um local privilegiado pelo seu aporte tecnológico conferido pelos equipamentos, instrumentais e materiais consumíveis, que aliados às técnicas ou ao saber fazer, resultam em tratamentos resolutivos e satisfatórios para as pessoas. Deve-se dizer que a literatura mostra que o exercício da prática cirúrgicorestauradora (NARVAI, 1992) e a produção de conhecimento científico nos Cursos de PósGraduação no Brasil (CAVALCANTE et al., 2008) formam um conjunto que possui um reconhecido avanço tecnológico.

Da mesma forma, é possível reconhecer os elementos do processo de produção do cuidado à saúde em que a sua prática esteja voltada para a atenção à saúde. Neste campo, as práticas das equipes de Saúde Bucal extrapolam os limites da boca e estão constituídas por um conjunto de ações que inclui a assistência odontológica individual e amplia seu campo teórico e prático em função dos determinantes sociais do processo saúde-doença-cuidado. Estes vinculam o adoecimento às condições de vida, do trabalho, da renda, da habitação, do saneamento e do lazer. Esta situação exige da atenção uma abordagem que transcende o âmbito da odontologia e também o da saúde, requerendo ações que envolvam outros setores da sociedade (NARVAI, 1992, 1994; BRASIL, 2006b, 2006c).

Tal perspectiva, por outro lado, busca atingir grupos populacionais por meio de ações de alcance coletivo com o objetivo de manutenção da Saúde Bucal, fortalecimento da autonomia das pessoas no controle do processo saúde-doença e adoção de hábitos saudáveis para a vida. Articula-se, também, com as outras disciplinas do campo da saúde, no sentido de identificar situações de risco comuns para agravos bucais e sistêmicos, buscando interagir com elas para elaboração de ações de saúde interdisciplinares (NARVAI, 1992; BRASIL, 2004, 2006c).

Nessa perspectiva, os saberes e práticas de Saúde Bucal Coletiva podem se fazer presentes na produção do cuidado à saúde pelos trabalhadores da equipe de Saúde Bucal, 
pelos profissionais das outras áreas da saúde e dos outros setores da sociedade (BRASIL, 2004). Por conseguinte, a prática da atenção em Saúde Bucal vai ocorrer quando o trabalhador de saúde reconhecer como objeto de trabalho para além do indivíduo, ou seja, a unidade elementar de um exemplar da espécie biológica humana, que não pode dividir-se sem desnaturar-se. Também para além da pessoa, que se refere à unidade social e jurídica, igualmente mínima, capaz, por exemplo, de contrair direitos e deveres e de ocupar lugares e hierarquias sociais estabelecidas. Reconhecê-lo como sujeito, unidade mínima homogênea, autônoma, psíquica, sujeito da fala e do falar (BAREMBLITT, 2010). Ayres (2001) também considera o sujeito em sua singularidade na sociedade, ou seja, a ipseidade ${ }^{10}$ do sujeito, historicamente constituído e protagonista do seu cuidado à saúde.

Isso nos encaminha para compreendermos a necessidade de ampliar os instrumentos ou meios de trabalho, incorporando tecnologias leves e leve-duras e criando dispositivos para que se expressem novos sentidos e significados acerca do que se faz, como se faz, para quem se faz, no sentido de possibilitar que a construção da intersubjetividade pelos sujeitos envolvidos no cuidado nos serviços de saúde contemple uma intencionalidade centrada no suporte para projetos de vida (AYRES, 2001).

Entretanto, deve-se considerar o fato de o ACS estar em contato intenso e contínuo com a população de sua microárea, em vista da periodicidade das visitas domiciliares, da sua presença no território da microárea e por fazer parte da comunidade, o que acaba o tornando um elo entre comunidade e equipe de saúde, no sentido de facilitar a comunicação e a troca de informações (SAKATA, 2009). Assim, exerce uma função de porta-voz das expectativas desta população com relação aos cuidados de Saúde Bucal. Isto tem o sentido positivo por ser revelador de uma demanda, aqui no caso, a respeito do desejo da população em ter seu acesso à assistência à Saúde Bucal, que necessita ser mais bem explorada, para sua compreensão e elaboração de estratégias que permitam acolher esta demanda e propor atividades de fortalecimento da atenção à Saúde Bucal.

10 O conceito de ipseidade do sujeito é trabalhado por Ayres (2001) quando discute o processo de intersubjetividade e o lugar do sujeito, enquanto um ser que atribuindo significados ao mundo, identifica a si mesmo. Assim, sustentado em filósofos modernos, Ayres (2001, p. 66) aponta que a ipseidade (pelo mesmo) indica que "o que permanece no tempo não é sempre um e mesmo predicado que nos define como sujeitos, mas uma auto-diferenciação que se afirma a cada vez que reconheço um outro, o que leva Heidegger (1995) a distinguir a individualidade/eu da individualidade/si. Esta última guarda o sentido forte de sujeito, de subjetividade. Segundo Heidegger, o eu refere-se ao ôntico, ao ente, ao existenciário; o si refere-se ao ontológico, ao ser, ao existencial. Segundo esse filósofo, estaremos falando verdadeiramente de sujeito quando nos referimos a essa identidade-si, ao Eu que é "a cada vez meu". 
A equipe da USF Rubi relata dificuldades semelhantes ao modelo de Saúde Bucal em outras áreas, no sentido da inserção de um modelo de saúde centrado nas pessoas, que privilegie as tecnologias leves e leve-duras, proporcionando encontros entre sujeitos. A exemplo do que acontece na área médica, ainda prevalece uma expectativa em torno do atendimento imediato e prescritivo.

[...] EF Aroeira: a gente está tentando mudar um modelo, mas um modelo que é um
modelo hegemônico onde a doença é mais valorizada e ainda está na cabeça de
muita gente, alguns vem procurar a gente dessa forma e ai cabe a gente a tentar
mudar da forma de oferecer, por que, teve um paciente que chamou a nossa atenção
que ele, era do NGA. Este paciente dá um trabalho quando ele vem aqui, a gente
perde quarenta minutos no acolhimento para explicar, ele chega e fala assim, "olha
eu não quero vir aqui, mais que uma vez por ano, faz assim, pede os meus exames,
eu só venho checar o exame". E o AERP é assim, [...] e a gente tentava explicar que
tinha a questão da prevenção, da promoção da diabetes, tinha que ver a questão do
pé diabético, olha me dá o pedido de exame por que eu não tenho tempo. Mas, o que
o senhor faz, eu sou aposentado, mas tenho ocupação, não poderei vir aqui por
qualquer coisa. Então, tem que ser um profissional diferente que conversa com ele,
até deixei anotado que conversei com ele, expliquei, mas ele disse que quer ser
tratado igual no AERP, não vem com essa história que me agendou consulta com
doutor aqui que eu não quero. (Reunião sobre Saúde Bucal, 08/02/2011).

Há usuários que expressam uma expectativa com um determinado modo de atendimento médico divergente do proposto pela unidade, recomendado para unidades que trabalham segundo a lógica da Estratégia Saúde da Família e para qualquer outro modelo de atendimento, demonstrando que esta dificuldade nas divergências entre o modelo de saúde oferecido e o esperado pela população não é uma situação exclusiva para a Saúde Bucal. Entretanto, a EF Aroeira traz uma sinalização para esta situação, que não deve ser "qualquer" profissional que deve conversar com o usuário. Mas deve ser um profissional diferente, sugerindo que as condutas dos profissionais podem ser diversas diante de uma mesma situação. Ao percorrermos os dados produzidos quanto à organização da agenda, a discussão da Saúde Bucal com a equipe e o caso do Sabiá Laranjeira, verificamos uma polaridade entre ações de saúde determinadas pela responsabilização com os sujeitos, famílias e comunidade, voltadas para projetos de vida para a atenção à saúde e, em outro polo, as ações que configuram o atendimento imediato, ações centradas no tecnicismo e restritas ao campo biológico.

Na sequência da discussão sobre a Saúde Bucal na unidade, realiza-se um comparativo com o atendimento médico, a respeito das formas diferentes de oferecer opções de atenção em casos de dor ou sofrimento. No caso do atendimento médico o paciente é acolhido e no caso da odontologia é solicitado que procure a UBDS, justificando a necessidade de ter um equipamento odontológico na unidade. 
[...] MD. Acácia: quando o paciente chega aqui, ele tem cadastro, as vezes ele não acompanha, tem um caso novo, ele nunca veio aqui, ele chega na unidade, a gente o recebe com esta porta aberta, [...] a gente atende e consegue resolver aquela demanda. Acho que isso facilita, por que consegue resolver o problema dele. A gente diz, é uma troca, [...] estou te convidando para vir aqui, para começar um caso novo, [...] Então a gente consegue atender, resolver, aquela demanda, que seria imediatista, para depois ele começar fazer o seguimento. Então você vai ver que tem vários pacientes tem caso novo, depois de ter passado como eventual, por que a porta de entrada dele foi um eventual, foi uma febre, foi dengue, foi uma coisa, uma dor.

EF Aroeira: se não atender como eventual, depois ele não volta mais, se você não me atendeu na dor, por que vou voltar na rotina.

MD Acácia: não vim na rotina, você quer que eu venha no seguimento, mas eu estava com dor e você não me atendeu, então eu acho que isso na parte médica facilita, uma coisa para a gente pensar, o fato da gente não ter a cadeira, é mais difícil, se tivesse, eu resolvi sua dor, mas depois você vai começar o seguimento, seria uma coisa para a gente pensar, me veio isto na cabeça agora, muitas vezes a gente ganha o paciente através desta entrada, na entrada para resolver uma coisa pontual, ele vem uma vez, vem uma segunda, vem a terceira, até entender o funcionamento da unidade e começar a realmente a seguir, né, tem alguns que vem uma vez, a não eu vou agendar, eu vou seguir, mas outros, eles vem as vezes, várias vezes de eventual, para depois ele começar a querer seguir, entender a lógica e gente tentar convencer. ACS Canela: o fato de ter aqui na cidade, muitos idosos, que vem daquele modelo antigo tradicional, que não funciona, eles falam, eles continuam. (Reunião sobre Saúde Bucal, 08/02/2011).

Há situações de agravos de Saúde Bucal que necessitam de intervenção imediata e um consultório odontológico na USF Rubi tornaria essas intervenções mais ágeis e contribuiria para o reconhecimento da população com relação à existência de atendimento odontológico na unidade, situação esta esperada segundo os documentos de avaliação do Ministério da Saúde (BRASIL, 2005)11. Ao considerarmos que a USF RUBI refere-se a uma unidade de Saúde da Família, com uma população adstrita em área territorial reconhecida, com a totalidade de domicílios cadastrados, com funcionamento há mais de 10 anos e com uma população estável, ou seja, população adulta e idosa, compreende-se que esta situação faz com que pessoas procurando a unidade pela primeira vez seja uma condição esporádica. Todavia, na Estratégia Saúde da Família, o atendimento clínico ou clínico-cirúrgico, com característica hegemônica de cunho restaurador, não deve ser a única opção de atenção à saúde.

Na literatura é possível encontrar relatos de profissionais a respeito da compreensão do trabalho do cirurgião-dentista na perspectiva da Atenção à Saúde Bucal. Uma investigação

\footnotetext{
${ }^{11}$ BRASIL. Ministério da Saúde. Fundação Oswaldo Cruz. Saúde da Família: avaliação da implementação em dez grandes centros urbanos: síntese dos principais resultados; elaborado por Sarah Escorel (Coord.); Lígia Giovanella; Maria Helena Mendonça; Rosana Magalhães; Mônica de Castro Maia Senna. 2. ed. Brasília, DF: Editora do Ministério da Saúde, 2005. 210 p.
} 
sobre a percepção de CD do Estado de Santa Catarina, a respeito de suas atividades nas equipes de Saúde da Família, relata as dificuldades em torno da comunidade e dos profissionais de saúde em compreenderem o trabalho do dentista para além do consultório. Assim, Gonçalves e Ramos (2010, p.305-306) citam um relato de dois dentistas:

[...] "Sem dúvida nenhuma a própria comunidade (é um limite). Eles não viram com bons olhos isso (a inserção do dentista na ESF). Tu tentas iniciar e as pessoas te limitam, a comunidade quer $\mathrm{o}$ atendimento curativo dentro do consultório, e pra grande maioria, o atendimento dentro do consultório é que é atendimento. Ir na casa não é atendimento, ir na escola não é atendimento, pra eles isso não é trabalho de dentista. Dentista tem que estar dentro da sala tampando buraquinho". (Carmesim)

"Eu brinco sempre assim: o dentista tem que deixar de ser o ET da equipe, porque historicamente ele é o ET da equipe. Quem é mais "metido" como eu, participa das reuniões e diz que não é só abrir e fechar buraco, que não, eu não vou ficar só no consultório. E a partir daí, eu comecei a ter um pouquinho mais de respeito dos profissionais". (Damasco)

Retomando o caso da Família do Sabiá Laranjeira, podemos verificar que sua demanda com relação à Saúde Bucal pode ser compreendida pelo serviço de odontologia do ponto de vista técnico e biológico, ou seja, um incisivo central com escurecimento e um quarto da coroa fraturada e possível necessidade de intervenção endodôntica.

Por outro lado, na perspectiva da Atenção à Saúde, a demanda do Sabiá Laranjeira, um adolescente, com "sorriso quebrado" devido a um dente anterior fraturado, pode ser o constrangimento por ter prejudicada uma das capacidades de expressar suas afeições, o sorriso. Esta necessidade do Sabiá está diretamente relacionada ao desenvolvimento de cidadania e de autonomia, o que é estimulado pela Terapia Ocupacional da USF Rubi, ao considerá-lo deficiente afetivo e não cognitivo.

[...] TO Araçá: a gente sabe muitas vezes, que o Sabiá Laranjeira ajuda a atualizar o site da empresa do pai, ele tem um mérito lá, a dificuldade dele é exatamente esta a relação com as pessoas, a parte afetiva é muito complexa, a família passou por uma série de situações, ele não tem um desenvolvimento afetivo, psíquico, de acordo com a idade dele, mas eu acho que muitas coisas que a gente julgava no início, quando começamos a atender, que eram cognitivas, a gente hoje vê que não são cognitivas, né, a dificuldade cognitiva dele é a de menor necessidade, [...] então, a gente inicialmente tem uma sensação dele não estar compreendendo, mas ele consegue realizar estas tarefas, não são tarefas simples, não são tarefas para alguém que esteja prejudicado cognitivamente, ele realiza, ele copia vários CDs para o pai. (Reunião de discussão de caso de família, 23/09/2010)

A compreensão da demanda do Sabiá Laranjeira a respeito do "sorriso quebrado" e das possibilidades do despertar para as relações de afetividade foi possível de serem 
construídas em função de estarem presentes, na USF Rubi, distintos atores sociais, cada um dotado de saberes parciais à respeito da família e desejantes de construir um processo saúdedoença-cuidado mais amplo. Estes distintos atores: o terapeuta ocupacional, o agente comunitário de saúde, o dentista, o psicólogo, alunos dos cursos de saúde do Campus de Ribeirão Preto, o médico, a enfermeira e outros se mostraram atentos para outras leituras das necessidades expressas pelo Sabiá Laranjeira. Assim, tratou-se e trata-se de um processo de desconstruções e construções de um saber a respeito da família e que foi provisório por ter sido verdadeiro para aquele momento e capaz de gerar ações no sentido do cuidado em saúde, especificamente a respeito dos cuidados de Saúde Bucal e o desenvolvimento da afetividade do Sabiá Laranjeira.

Por outro lado, para parte da equipe, a Saúde Bucal é reconhecida como especialidade de relevante importância com relação à demanda da população e com relação a medidas de controle das doenças bucais, de atuação exclusiva do cirurgião-dentista e voltada para medidas de prevenção.

[...] ALM Pinheiro: é assim, com a odontologia ainda não tive qualquer contato, apenas na reunião de psiquiatria em que participamos, mas acho a odontologia extremamente importante, até por que são diferentes áreas de atuações, e o médico não é competente para saber das questões dentárias, bucais, odontológica. É uma demanda importante da população. Até a década de 70, 80 um dos principais problema da população era questão mesmo de falta de conhecimento sobre a higiene bucal, antigamente, não sei, não tinha modos diferente de se tratar, esta questão de prevenção em Saúde Bucal é extremante importante para passar conhecimento de educação para a pessoa.(Reunião sobre Saúde Bucal, 08/02/2011).

Reibnitz Júnior, Caetano e Prado (2009, p 192) investigaram, em alunos de cursos de odontologia em Santa Catarina, a percepção com relação às atividades do cirurgião-dentista e sintetizaram dois relatos que remetem a uma visão limitada quanto à prescrição de condutas e da ação de caráter preventivista.

[...] Como as pessoas estão doentes, com infecção na boca, com perda dos dentes por várias causas, é preciso fazer prevenção. Trabalhar a conscientização das pessoas em relação aos problemas de saúde, motivá-las e tentar convencê-las a mudarem hábitos errados. Mostrar como se faz a prevenção, dar instruções de como cuidar realmente da sua saúde geral e saúde oral, ensinar sobre escovação, como usar o fio dental, como manter os dentes na boca, como usar o flúor e como se alimentar, e a importância de procurar o dentista periodicamente. Tudo isto para capacitá-las ao autocontrole de sua saúde. O principal é convencer a população do que é bom para ela, fazendo-a aceitar a mudança para esse novo modelo de saúde e partir para a prevenção.

Só restaurar não vai resolver o problema de todo mundo. A Odontologia precisa se voltar à prevenção. O povo precisa de educação para se prevenir. As pessoas precisam ter consciência sobre todos os fatores que geram doenças bucais para poderem controlá-los e conseguir a prevenção. O dentista deve mostrar que a prevenção é mais importante do que o tratamento odontológico. 
Uma síntese neste ponto da discussão, sobre o eixo Assistência, Atenção e a Clínica Ampliada na Equipe Rubi, vai submeter os pesquisadores deste estudo ao questionamento a respeito das contribuições que as ações de Atenção à Saúde Bucal possam conferir à sociedade, em vista do dilema em torno da valorização da assistência odontológica em detrimento da Atenção à Saúde Bucal, do reducionismo da prática de Saúde Bucal no sentido de localizá-la em ações preventivas e, por outro lado, a constatação de que, ao se colocar em prática as ações de Atenção à Saúde bucal, se faz necessário restringir o número de horas disponíveis para assistência odontológica.

Uma das formas de elucidar esse questionamento pode ser a compreensão da categoria trabalho na Saúde Bucal a partir do modelo econômico que estamos inseridos, o capitalismo.

Segundo Pereira e Lima e Lima (2008), na teoria marxista, o capital não é uma coisa, mas sim relações de produção do modelo econômico, sendo que Karl Marx elaborou um esquema explicativo para elucidar e explicar as relações sociais no interior do capitalismo, a partir de abstrações da realidade, ou seja, separar, no campo intelectual, um ou mais elementos de uma totalidade complexa, como via para compreensão da realidade.

Então, Karl Marx, ao descrever as relações sociais que se configuram na sociedade em função do modelo econômico-capitalista, diz que tudo o que é produzido no interior da sociedade é reconhecido como mercadoria, no sentido do bem comerciável. A consequência disto é que podemos reconhecer, na prática da assistência odontológica, as mercadorias que são produzidas para a sociedade: a restauração de um dente, a extração dentária, a remoção de cálculos, próteses total, parcial removível, fixa e assim por diante. Quanto às mercadorias produzidas pela atenção à Saúde Bucal temos: educação em saúde, acolhimento dos sujeitos, vínculo sujeito (profissional)/ sujeito (usuário), autonomia em cuidados em saúde, projetos de vida, dentre outras (PEREIRA, LIMA, 2008; CODO, 1994), portanto, "mercadorias" diversas a partir da intencionalidade colocada para seu processo de produção.

Dessa forma, uma segunda questão a ser percebida na realidade em que estamos inseridos é a compreensão do trabalho empregado para gerar esses produtos. A teoria marxista abstraiu duas vertentes que existem simultaneamente e são constituintes do processo de trabalho.

Uma delas é o trabalho abstrato, considerado como simples gasto de energia humana, físico ou intelectual e desprovido de qualquer especificidade. Nesta vertente, se localizam as questões histórico-sociais do trabalho, ou seja, a desapropriação dos meios de produção do trabalhador, a sua apropriação pelo capital, a obtenção da mais-valia pelo capital em função da exploração da força de trabalho, levando à alienação dos trabalhadores com relação aos 
produtos gerados via atividade de trabalho. É pelo trabalho abstrato que se atribui o valor de troca que, em dinheiro, representa o preço (PEREIRA, LIMA, 2008; CODO, 1994).

A outra vertente é o trabalho concreto que define o valor de uso das mercadorias a partir das necessidades a serem satisfeitas, localizando-as em objetos externos. No trabalho concreto é onde residem as questões técnico-materiais da atividade do trabalho, que na odontologia representa o aparato tecnológico dos equipamentos, materiais consumíveis e técnicas e que correspondem ao trabalho morto. No contexto do modelo econômico do capitalismo, o capital, enquanto relações sociais previamente estabelecidas, vai possibilitar o aumento ou manutenção do trabalho morto, acumulado, por meio do trabalho vivo (PEREIRA, LIMA, 2008; CODO, 1994).

A demanda apresentada pela população nos serviços de Saúde Bucal, quer seja nos serviços de urgência, de acolhimento ou da recepção, é expressa pelos usuários na forma de agravos de Saúde Bucal, tais como dor de dente, dente cariado ou necessidade de prótese ou tratamento de rotina, e acaba por remeter à satisfação de necessidades por meio de procedimentos cirúrgico-restauradores. Assim, o tratamento endodôntico, restaurações, confecções de próteses, exames bucais, profilaxias, raspagens conformam a carência de produtos ou mercadorias do trabalho desenvolvido pelos trabalhadores de odontologia.

No âmbito coletivo, as necessidades levantadas por meio dos Levantamentos Epidemiológicos de Saúde Bucal e Critérios de Risco para doenças bucais também são expressas na forma de ocorrência dos agravos bucais, gravidade e indicação de tratamento, remetendo diretamente ao procedimento cirúrgico-restaurador, a exemplo da cárie dentária, que se apresenta na forma de dentes hígidos, cariados, perdidos ou restaurados, com as respectivas indicações de tratamento em torno da restauração, confecção de coroa, extração (BRASIL, 2009), denunciando diretamente a carência de necessidades das mercadorias a serem produzidos pelo trabalho odontológico.

Essa situação pode ser uma das explicações para que os procedimentos cirúrgicorestauradores sejam reconhecidos como necessidade e objeto de desejo em detrimento de um conjunto maior que englobe as ações clínico-cirúrgicas e da clínica ampliada, em razão de estarem diretamente relacionados com as demandas expressas pela população.

A esse contexto do estabelecimento do valor de uso a partir das necessidades, aliamos o fato de que o estilo de vida contemporâneo, determinado pela essência do capitalismo, produção-consumo, pode levar os usuários a perceberem os serviços de saúde na forma de consumo de procedimentos, tais como a extração ou restauração dentária, na perspectiva da aquisição de saúde, sem perceber que o procedimento em si é apenas reparador de uma 
condição de saúde perdida, uma reparação ou mutilação. Esse funcionamento pode causar nas pessoas uma naturalização tanto do processo de adoecimento, como a sua consequência mais radical, o edentulismo. Pode, também, transparecer em processos eternos, inevitáveis, que sempre existiram e existirão como, por exemplo, pais que acreditam ser natural que seus filhos terão seus dentes decíduos cariados e removidos, uma vez que "cairão" para dar lugar a um novo dente, o dente permanente. Ou na crença de que, naturalmente, durante a vida, os dentes serão acometidos por doenças que causarão sua perda, tornando a pessoa desdentada e, consequentemente, levando a usar uma nova dentição, desta vez artificial, a dentadura.

Portanto, as demandas apresentadas pelas pessoas são desprovidas de uma reflexão histórico-social dos agravos de Saúde Bucal e da concepção do processo saúde-doençacuidado. Dessa forma, os procedimentos cirúrgico-restauradores são vistos como socialmente mais relevantes, como via para restabelecer, de forma imediata, as necessidades construídas e percebidas pela população para a recuperação da Saúde Bucal. Por outro lado, tomando-se a cárie dentária como elemento para repensar a forma como as demandas da população são conformadas nos serviços, podemos verificar que, dentre as informações disponíveis, há um contexto histórico-social que determina o processo saúde-doença-cuidado da cárie.

Há evidências de relação direta entre hábitos alimentares com a ocorrência da cárie dentária, uma vez que, as populações ditas primitivas, cuja alimentação era baseada na caça, frutas e pesca, praticamente não tiveram a experiência de cárie. Somente a partir da ampliação das plantações de cana-de-açúcar no Novo Mundo, por volta de 1700 e na Europa, a partir de 1800, e da adição da sacarose na alimentação, observou-se uma pandemia de cárie no mundo (MAIA; SAMPAIO; SILVA, 2006). Pinto (2008) afirma que no Brasil, em função da queda das exportações do açúcar a partir do século XVIII, estimulou-se o consumo interno, sendo que em 1920, o consumo per capita de açúcar era de $20 \mathrm{~kg} /$ ano e a população possuía, em princípio, níveis aceitáveis de prevalência de cárie dental. Em 1996, o consumo per capita chega a 50 kg/ano e registra-se uma explosão de cárie dentária no Brasil. Esta relação também foi verificada entre ingleses (PINTO, 2008).

Sabe-se que, para parte da sociedade contemporânea, o açúcar é fonte de prazer, está relacionado à troca de afetividades entre pessoas e é uma das fontes de energia com valor econômico mais baixo, tornando o seu acesso universal, sendo que outros adoçantes e fontes de energia, com propriedades cariogênicas reduzidas ou inexistentes, possuem valores econômicos maiores, levando à restrição de seu consumo por parte da população economicamente menos favorecida (MAIA; SAMPAIO; SILVA, 2006; PINTO, 2008). 
Pinto (2008) diz que o consumo médio de açúcar mundial mantém-se entre 29 e 43 kg/ano e, por outro lado, tem-se observado uma redução da prevalência da cárie dentária em países desenvolvidos e em desenvolvimento. Esta redução é atribuída a outros fatores de proteção à cárie que, associados, promovem a prevenção de novas lesões. Podemos citar como medidas que resultaram nessa redução a expansão e controle da fluoretação da água de abastecimento público, o acesso e o uso adequado do dentifrício fluoretado, a adoção na prática do CD de medidas de prevenção individuais e técnicas de intervenções odontológicas menos invasivas.

Entretanto, tem-se reconhecido o consumo do açúcar como hábito da vida contemporânea que, associado a outros fatores, eleva o risco para o desenvolvimento de outros agravos de saúde, tais como a hipertensão arterial, obesidade, cardiopatias, diabetes mellitus, configurando em risco comum para doenças crônicas.

As circunstâncias histórico-sociais da cárie dentária ocorrem dentro do modelo econômico do capitalismo que tem sua essência no seu próprio crescimento e necessita ampliar-se constantemente, criando novas necessidades de consumo ou apropriando-se de necessidades nunca antes transformadas em mercadoria (CODO, 1994). Dessa forma, consideramos que as relações de produção do capitalismo não podem prescindir das necessidades humanas, visto que a sua essência está nos desejos.

Por outro lado, Baremblitt (2002), discutindo os conceitos e práticas da autoanálise e autogestão, diz que na nossa civilização, a complexidade da vida social atingiu seu máximo expoente em toda a história da humanidade e caracteriza-se por ter produzido uma soma de saberes, nestes últimos duzentos anos, maior do que havia conseguido em dois mil anos, ou seja, houve uma produção e aplicação do conhecimento muito intensas. Da mesma forma, a civilização tem produzido um saber acerca de seu próprio funcionamento como objeto de estudo e tem gerado profissionais, intelectuais e especialistas que são conhecedores desta estrutura e do processo da sociedade em si. Entretanto, esses profissionais têm-se colocado a serviço das grandes entidades proprietárias da riqueza, do poder, do saber, do prestígio ou do Estado. Em consequência, os povos em sentido amplo, a sociedade civil, têm-se visto despossuídos de um saber que tinham acumulado através de muitos anos acerca da própria vida e de seu próprio funcionamento. Então, esse conhecimento criado e acumulado durante anos de experiência vital fica subordinado ao saber científico e tecnológico, ao saber dos especialistas. Estes especialistas são os dos ramos produtivos primários, secundários e terciários, da produção de bens materiais, inclusive aqueles indispensáveis à sobrevivência e relacionados aos problemas de saúde, de educação, aos assuntos familiares e outros. Nesse 
contexto, os especialistas conhecem e decidem prevalentemente segundo os interesses de classes, níveis hierárquicos e grupos dominantes aos quais pertencem parcialmente. No entanto, Baremblitt (2002) ressalta que não se deve supor uma intenção deliberada dos especialistas ou técnicos nesse sentido, uma vez que seu saber, em si mesmo, já está produzido por instrumentos e gera resultados que privilegiam os interesses já citados.

Em função disso, Baremblitt (2002, p.16) diz que uma das tarefas do institucionalismo é questionar as necessidades colocadas como básicas, por meio de demandas espontâneas, das exigências de produtos e de serviços correspondentes. Porque o institucionalismo

\begin{abstract}
vai tentar mostrar que em todas as épocas da história, mais particularmente na nossa, não existem necessidades básicas "naturais", não existem demandas "espontâneas", pois em todas e em cada uma dessas organizações que acabamos de descrever, a noção das necessidades é produzida, assim como a demanda é modulada, isto é, aquilo que os povos pensam que todos os membros de uma população e todos os povos do mundo precisam como "mínimo" não existe. Esse "mínimo" é gerado em cada sociedade e é diferente para cada segmento da mesma. Mas ainda dentro do condicionamento histórico, as comunidades que têm alguma noção vivencial acerca de suas necessidades a perdem, de modo que já não sabem mais do que precisam e não demandam o que "realmente" aspiram, mas acham que necessitam daquilo que os experts dizem que elas necessitam e acham que pedem o que querem e como querem, mas na verdade, precisam, querem e pedem o que lhes inculcam que devem necessitar, desejar e solicitar.
\end{abstract}

Dessa forma as demandas que se apresentam nos serviços de saúde, limitadas a queixas orgânicas, podem não corresponder às reais necessidades das pessoas. Estas possuem um sentido de consumo de serviços de saúde, condizente com as características da sociedade capitalista. Essa forma de relacionamento tende a gerar dependência dos usuários com os serviços de saúde, não possibilita o desenvolvimento da autonomia, no sentido da compreensão do adoecimento e da construção de projetos de vida.

Somando-se a essa discussão, Botazzo (2006) vai ampliar o objeto da Saúde Bucal ao resgatar o conceito de bucalidade, que está composto pelos trabalhos de manducação, linguagem e erótica. Manducar corresponde ao trabalho de apreender, triturar, insalivar e deglutir. Portanto, realiza consumo do mundo, ação que põe em relação as estruturas orgânicas e visíveis localizadas na parte superior do aparelho digestório com as vísceras não visíveis localizadas mais abaixo. Esta estrutura garante a sobrevivência do homem em sua natureza, a preservação ou reposição dos elementos que constituem sua unidade corpórea.

$\mathrm{Na}$ ação de manducar também é produzido o gosto ou formação do paladar, porque, para o homem, o hábito de se alimentar é uma atividade social, produzida culturalmente. Aqui reside uma relação entre a atividade de manducar e a satisfação, o gozo, que vão além das necessidades fisiológicas. Botazzo (2006, p.13) diz que a satisfação e gozo bucais, conformados pela cultura, esbarram na razão e no desejo: 
[...] frequentemente comemos o que não devemos ou o que certa racionalidade recomenda, ou mais ou menos ou, ainda não do modo como devíamos, de sorte que tudo isto resulta atravessado pelo psiquismo o que põe o sujeito em conflito consigo e com os outros.

Assim, a manducação pode proporcionar que os prazeres bucais repitam-se incessantemente e não havendo dispositivos reguladores, a manducação pode tornar-se deletéria para o próprio homem (BOTAZZO, 2006).

Esses elementos da manducação se repetem nas outras atividades da boca. Produzemse palavras e as consumimos, somos obrigados a pensar naquilo que falamos e, não raro, dizemos o que não queríamos dizer; também a palavra exagerada ou equivocada pode revelarse deletéria. Quanto às relações amorosas, produzem-se atos bucais sexuais, o consumo e o deleite com o corpo do outro e pode resultar em conflito entre razão e emoção, por outra vez, a boca fará o que não devia ou de modo não recomendado (BOTAZZO, 2006).

Posto que as três atividades da bucalidade são dimensões da vida do homem em sociedade, resultando na produção social da boca humana, este funcionamento da boca e esta fisiologia estão permanentemente encobertos, como assinala Botazzo (2006).

Dessa forma, podemos associar que a demanda apresentada pelos usuários nas unidades de saúde pode não representar as suas reais necessidades ou pode estar subdimensionada, em função da ausência de percepção dos usuários com relação ao funcionamento da boca na sua dimensão de produção social, a bucalidade.

Outro aspecto que contribui para que a demanda dos usuários se apresente de forma limitada ou distorcida pode residir na forma como a área de odontologia vem se organizando e ofertando os cuidados de Saúde Bucal para a sociedade. Baremblitt (2002) alerta para o fato de que a demanda não é espontânea e nem é o primeiro passo de um processo, mas a demanda é determinada, desde o princípio, pela oferta.

Desse modo, ao resgatarmos a descrição da forma como a odontologia se inseriu nos serviços públicos apontada na introdução deste estudo, verificamos que a mesma se apresenta à sociedade ofertando assistência odontológica, procedimental, orgânica e preventivista, com poucas experiências relatadas de atenção à Saúde Bucal (OPAS, 2006). Freitas (2008, p. 212), ao analisar as relações entre cárie, epidemiologia e sociedade, nos apresenta uma síntese que denomina de odontologização, a qual se refere à percepção que têm os dentistas de como a doença ocorre na população: 


\begin{abstract}
A visão odontológica trabalha, predominantemente, com aspectos como: doença multifatorial e de fluxo unidirecional; ou seja, um indivíduo só pode caminhar da saúde para a doença e nunca ao contrário. Não há cura para a doença. As estratégias preventivas se dão, para além da fluoretação de águas, por suplementações individuais de flúor tópico por diversas formas e por campanhas educativas, que propõem o ensino de higiene oral e dos fatores etiológicos, da mudança de hábitos e comportamentos dietéticos, sempre com uma abordagem isolacionista e, sem querer parecer tautológico, com aquilo que chamei em artigo anterior, de "concepção odontológica de mundo"
\end{abstract}

Gomes e Schraiber (2010), ao estudarem a alienação nas práticas de saúde, verificaram que a oferta de serviços também modula a demanda dos usuários para serviços médicos, de modo que, ao ofertar um determinado tipo de serviço para uma comunidade, esta oferta é comunicada entre os moradores que passam a demandar o serviço.

Outro aspecto a ser observado diz respeito às informações existentes a respeito da quantidade de serviços ofertados e as necessidades de tratamento recuperador da Saúde Bucal. A Pesquisa Nacional por Amostra de Domicílios mostrou que em relação ao acesso e à utilização de serviços de saúde no ano de 2003, havia, ainda, uma grande parcela de brasileiros que nunca foi ao dentista: $15,9 \%$ da população ou 27,9 milhões de pessoas. Comparando o mesmo dado ao do ano de 1998, constatou-se redução em vista dos 18,7\% no estudo anterior. A maior concentração dos que nunca consultaram o dentista estava entre os menores de cinco anos, com 81,8\%. Já para o grupo etário de 5 a 19 anos, a porcentagem era de $22,1 \%$ e para os que tinham 65 anos ou mais, 6,3\% (BRASIL, 2005).

Enquanto $31 \%$ da população com rendimento mensal familiar de até um salário mínimo nunca fez uma consulta odontológica, a proporção caiu para 3\% entre os que tinham rendimento superior a 20 mínimos. Nos atendimentos odontológicos, a cobertura do SUS e dos planos de Saúde é baixa: 30,7\% e 16,2\%, respectivamente (BRASIL, 2005).

Quanto à oferta de serviços em termos quantitativos, o documento intitulado Desenvolvimento de Sistemas e Serviços de Saúde, que trata da Política Nacional de Saúde Bucal do Brasil (OPAS, 2006), faz uma comparação entre o número de equipes de Saúde Bucal nos anos de 2002 e 2005, sendo possível verificar uma ampliação da ordem de 8.342 novas equipes, significando um incremento de $270 \%$. Quanto à ampliação da cobertura populacional, em 2002 havia 26.170.330 pessoas cobertas por equipes de Saúde Bucal e em 2005 passou para 61.823 .337 , correspondendo a $136 \%$ de aumento.

O relatório prévio da pesquisa nacional de Saúde Bucal coordenada pelo Ministério da Saúde do Brasil (PRIMEIROS RESULTADOS DO PROJETO SBBRASIL, 2010) mostrou que no final do ano de 2010 possuíamos 20.300 equipes de Saúde Bucal e que, do ano de 
2003 ao de 2008, passaram a ter acesso ao dentista 17,5 milhões de brasileiros, havendo impacto maior para as famílias com renda de até dois salários mínimos.

Pode-se considerar um avanço em termos qualitativos da atenção à Saúde Bucal, em razão dos investimentos do Ministério da Saúde proporcionarem maior impacto positivo às famílias de menor renda, priorizando, dessa forma, a parcela da população mais fragilizada para a cárie dentária, porque os estudos epidemiológicos apontam para uma associação entre maior incidência e severidade de cárie dentária em crianças de famílias cuja renda é menor, cujos pais possuem baixa escolaridade e onde há maior frequência no consumo de açúcar (FREITAS, 2008).

Por outro lado, Freitas (2008, p. 211), em sua reflexão em torno da cárie, epidemiologia e sociedade, nos apresenta dados de estudos epidemiológicos que apontam para o fato de que a melhoria das condições de Saúde Bucal independe do cirurgião- dentista:

[...] O estudo concluiu que a atenção odontológica é fator de proteção para as necessidades de tratamento, mas aumentou a taxa de dentes restaurados e extraídos no grupo, embora não se possa atribuir significância estatística a estes aumentos. Mostrou também que o acesso ao dentista não alterou a progressão da doença, seu padrão de distribuição na população ou o risco de adoecer.

O Controle Social é um aspecto adicional a esta reflexão e, neste sentido, podemos considerar o relatório da III Conferência Nacional de Saúde Bucal (BRASIL, 2004, p.115). Tal documento consegue retratar a situação de exclusão social causada pela ausência de uma proposta de Saúde Bucal para o país até então, e, ao mesmo tempo, indica as diretrizes para a construção de uma política nacional que estimule a construção de novas práticas, fundamentada na Saúde Bucal para a dignificação da vida e conquista da cidadania. Segundo o relatório, esta política dependeria do desenvolvimento de um modelo de atenção em Saúde Bucal orientado pelos princípios da universalidade do acesso, da integralidade, da equidade e caracterizado pela resolutividade das ações que realiza.

\begin{abstract}
A banalização da situação de exclusão social no Brasil dificulta a explicitação pública como questão política, da absurda falta de garantias de acesso à atenção em saúde bucal. Há que se denunciar, com indignação, essa enorme dificuldade de acesso à atenção em saúde bucal, independentemente do modelo em que essa atenção atualmente se pauta. É preciso reverter o atual modelo (cirúrgico, restaurador, ineficiente, monopolizador, de tecnologia densa, de alto custo e elitista) em favor de um modelo de atenção integral em saúde bucal, que leve em conta as necessidades de cada comunidade, de acordo com seu perfil epidemiológico e reorganizar a estrutura de funcionamento, os métodos e os processos com os quais se construiu a atenção em saúde bucal da população brasileira, redefinindo os papéis da União, dos estados e dos municípios no processo da atenção.
\end{abstract}

Ao considerarmos as características democráticas das Conferências de Saúde e de Saúde Bucal no Brasil, podemos concluir que o reconhecimento da necessidade de superar um modelo assistencial, no sentido de caminharmos para outro, que contemple a atenção integral em saúde 
bucal, é percebido e reivindicado por parte da sociedade, conferindo-lhe legitimidade e conformando uma utopia ativa.

Com o intuito de finalizar a discussão em torno do dilema entre Assistência, Atenção e a Clínica Ampliada na USF Rubi, deve-se dizer que as três formas de construir o cuidado em saúde não são antagônicas, mas são complementares, inclusivas e devem compor-se para potencializar o cuidado. Para exemplificar essa complementariedade, podemos recorrer à demanda do Sabiá Laranjeira, em que a fratura do dente anterior lhe causava a reabsorção da raiz, o que levaria à perda do dente. Portanto, naquele momento, a ação de saúde necessária era de Assistência Odontológica, uma ação endodôntica de caráter urgente.

Entretanto, em um momento posterior, no contexto da Atenção à Saúde e da Clínica Ampliada e por meio da discussão em equipe na USF Rubi, pautada pela interdisciplinaridade e pelo compromisso da equipe, foi possível compreender o processo de saúde-adoecimento em que o Sabiá estava inserido, as circunstâncias familiares, as dificuldades para a sua adesão aos agendamentos e, principalmente, a relação entre o "sorriso quebrado" e a afetividade de um adolescente. Este processo possibilitou que a equipe elaborasse um projeto terapêutico comum, melhorando a adesão do Sabiá ao tratamento odontológico, à terapia, ao estímulo para o desenvolvimento da sua cidadania e às ações de prevenção de Saúde Bucal.

No mesmo sentido, podemos perceber que a restrição dos horários para assistência odontológica na UBDS Citrino não causou aumento do tempo de espera para iniciar o tratamento odontológico, ou seja, o tempo de espera na USF Rubi, Prata e Esmeralda sempre foi de, no máximo, quatro semanas. O tempo de espera é menor nas cinco USF quando comparado com aquele de outras unidades pertencentes à área de referência da UBDS Citrino, que chega a ser de um ano ou mesmo não oferecendo acesso, como é observado na prática cotidiana. Quanto ao atendimento de urgência, este é oferecido nos períodos da manhã, tarde e vespertino.

A consulta odontológica realizada nas USF, que é prévia ou simultânea ao tratamento odontológico na UBDS Citrino, acaba potencializando a assistência, ao abordar um conjunto de procedimentos que são inerentes a qualquer assistência odontológica, ou seja, levantamento da história de saúde, ações de prevenção, criação de vínculo sujeito/usuáriosujeito/profissional e exame para classificação de risco para agravos bucais, tornando o número de sessões necessárias ao tratamento e as faltas aos agendamentos menores.

A conformação de um campo de conhecimento e práticas de saúde bucal na USF Rubi ampliou o acesso à Atenção à Saúde Bucal, a exemplo do caso da Família do Sabiá Laranjeira, em que a ação de supervisão de escovação dentária, que incluía a aquisição de 
dentifrício e escova dentária, foi realizada por profissionais da Terapia Ocupacional, com um duplo objetivo, melhorar o hábito de higiene bucal e estimular a socialização do Sabiá. Desse modo, este campo de conhecimento e de práticas de Saúde Bucal na equipe produz espaços para a criação de ações interdisciplinares e possibilita que os sujeitos/usuários estejam mais expostos a alternativas de cuidados de saúde para serem construídos com os sujeitos/profissionais, o que vem ao encontro da construção de práticas que contemplem o princípio da integralidade na saúde. Essa composição do processo de trabalho em saúde leva a uma ampliação na oferta do cuidado em Saúde Bucal, mas principalmente, a uma melhora na qualidade da Atenção à Saúde e a possibilidades de construção de Projetos de Vida pelos sujeitos/usuários e sujeitos/trabalhadores.

\begin{abstract}
AL Agáti: o grupo que ele faz é junto com outro rapaz e é um grupo de atividade de vida diária, que é uma atividade de autocuidado e a atividade de vida prática, que é a parte de manuseio de dinheiro, de vida, das questões do dia a dia mesmo e ela está investindo bastante na saúde bucal dos dois, mesmo porque ele não tinha nem escova de dente na casa dele. Então, ela conversou com o pai dele, só tinha uma escova na casa, conversou sobre a importância disso e havia até trabalhado com ele para capacitar para compra de escova de dente, para depois trabalhar mesmo a saúde bucal. (Reunião de discussão de casos de família de 01/07/2010).
\end{abstract}

Entretanto, uma das dificuldades que ocorre na Atenção à Saúde Bucal é a limitada oferta de atendimento especializado para os usuários que concluíram o seu atendimento básico e necessitam de acompanhamento especializado, tornando-a fragilizada. Se tomarmos como exemplo a necessidade do tratamento endodôntico do Sabiá, o tempo de espera, atualmente, é de um ano. Embora o Ministério da Saúde tenha ampliado a atenção secundária por meio da criação dos Centros de Especialidades Odontológicas, há um déficit entre as necessidades e as ofertas de procedimentos, cuja demanda reprimida maior são as próteses totais, ou seja, 3 milhões de idosos necessitam de próteses nas duas arcadas e 4 milhões em uma das arcadas. Essas necessidades e a restrita oferta de procedimentos especializados configuram uma dívida social que foi acumulada nas últimas décadas. A partir do governo do presidente Luiz Inácio Lula da Silva, houve iniciativas no sentido de reduzir este déficit, cuja ação concreta resultou na criação das 853 Centros de Especialidades Odontológicas (PRIMEIROS RESULTADOS DO PROJETO SBBRASIL, 2010).

Por outro lado, torna-se irrefutável a ampliação do cuidado em Saúde Bucal no sentido das práticas de Atenção à Saúde e Clínica Ampliada diante da análise dos estudos epidemiológicos apresentada por Freitas (2008), na qual a assistência odontológica apenas recupera os danos causados pela cárie dentária, sendo necessária a ampliação da prática para 
abordagem de um processo saúde-adoecimento diretamente relacionado com o modo de vida contemporâneo.

Os estudos epidemiológicos têm proporcionado contribuições importantes para a Saúde Bucal, mas estão focados nas necessidades de tratamento e não contribuem efetivamente para a minimização do risco para o adoecimento. É necessária a produção de informações que avancem no conhecimento dos mecanismos causais do processo de adoecimento por cárie dentária, a exemplo da incorporação de categorias sociais que possam ser verificadas como condicionantes, ou não, do processo saúde-doença-cuidado.

Considerando esse quadro e o contexto de organização das práticas de Saúde Bucal, dentre as leituras possíveis, poderíamos dizer que a tensão vivida na USF Rubi entre as práticas assistenciais e de atenção à saúde pode estar determinada pela alienação, ou seja, pela forma como os profissionais se reconhecem e se produzem sujeitos no processo de produção de cuidados em saúde.

\subsection{Alienação no processo de produção de cuidado em saúde pela USF Rubi.}

Gomes (2010) faz um estudo sobre o trabalho médico e alienação, abordando as transformações das práticas médicas e suas implicações para os processos de humanização/desumanização do trabalho em saúde. O estudo está fundamentado na discussão em torno da alienação baseada em Karl Marx, tendo como referência György Lukács, em sua obra Ontologia do Ser Social. Assim, vamos discutir a Alienação no processo de produção do cuidado em saúde pela USF Rubi, tomando como referência o estudo de Gomes (2010).

A etimologia descreve a palavra alienação como derivada do adjetivo alius, que significa outro e que resulta em diversas expressões, tais como tornar outro, passar para outro ou apropriado para o outro (GOMES, 2010).

Embora alienação seja um termo bastante antigo na história humana, o autor que primeiro discutiu a questão da alienação foi Rousseau, na sua obra Contrato Social, conferindo-lhe um sentido restrito a alienação de bens. Por outro lado, Hegel dá ao conceito de alienação uma dimensão de análise e elaboração filosófica. Feuerbach e Marx, posteriormente, fazem uma nova discussão a respeito deste conceito, o que mais tarde se tornaria elemento obrigatório nas análises filosóficas e sociológicas, em geral, e no campo do trabalho em particular (GOMES, 2010). 
Assim, Marx ao desenvolver o conceito teórico para alienação, partiu de um pressuposto fundamental, que é a compreensão do Ser como necessariamente dotado de objetividade. Marx12 (2004, apud GOMES, 2010, p.137) diz:

\begin{abstract}
Que o homem é um ser corpóreo, dotado de forças naturais, vivo, efetivo, objetivo, sensível significa que ele tem objetos efetivos, sensíveis como objetos de seu ser, de sua manifestação de vida (lebensäusserung), ou que ele pode somente manifestar a sua vida em objetos sensíveis, efetivos (wirkliche sinnliche Gegenstände). É idêntico: Ser (sein) objetivo, natural, sensível e ao mesmo tempo ter fora da si objeto, natureza sentidos fora de si é a mesma coisa que sermos nós próprios objetos, natureza, sentido, ou ser objeto mesmo, natureza, sentido para um terceiro. A fome é uma carência natural; ela necessita, por conseguinte, de uma natureza fora de si, de um objeto fora de si, para se satisfazer, para se saciar. A fome é a carência confessada de meu corpo por um objeto existente (seienden) fora dele, indispensável à sua integração e externação essencial. Um ser que não tenha sua natureza fora de si não é nenhum ser natural, não toma parte na essência da natureza. Um ser que não tenha nenhum objeto fora de si não é nenhum ser objetivo. Um ser que não seja ele mesmo objeto para um terceiro ser não tem nenhum ser para seu objeto, isto é, não se comporta objetivamente, seu ser não é nenhum [ser] objetivo. Um ser-nãoobjetivo é um não-ser (Marx, 2004:127).
\end{abstract}

Gomes (2010) nos alerta de que essa compreensão de Ser como ontologicamente dotado de objetividade não exclui, no interior dessa matriz teórica, a possibilidade de elaborações e abordagens com relação a subjetividades, muito pelo contrário, a compreensão da subjetividade dar-se-á em termos diferentes, por vezes antagônicas em relação a outras correntes teóricas, sendo que a dialética subjetividade/objetividade será a forma privilegiada para abordagem dessa temática.

A partir da concepção do Ser humano como Ser objetivo e objetivante no mundo, Marx vai elaborar a temática da alienação, compreendida como expressão teórica de um processo complexo, contraditório, por vezes permeado por aspectos subjetivos, ora objetivos. Em Marx, o conceito de alienação se encontra alicerçado em uma contradição entre o homem e suas objetivações (GOMES, 2010). Para Codo (1994), alienação é o mistério de ser e não ser ao mesmo tempo e no mesmo momento. Este autor exemplifica dizendo que o homem alienado é um homem desprovido de si mesmo.

A alienação constitui-se mais em processo do que um estado em si. É uma relação contraditória estabelecida entre a capacidade humano-genérica e a sua repercussão sobre a personalidade dos diferentes indivíduos concretos. Atribui-se à capacidade humano-genérica o caráter genérico do homem, expresso através do trabalho, da produção e da reprodução da vida material, do trabalho que produz a vida (GOMES, 2010; SILVA, 2008). Em outras

\footnotetext{
${ }^{12}$ MARX, K. Manuscritos econômico-filosóficos. São Paulo. Boitempo, 2007.
} 
palavras, trata-se do trabalho empreendido pelo homem para corresponder as suas objetivações.

Assim, o agir humano, por meio do objetivar-se, do inscrever suas marcas humanas no mundo, do constituir objetividades às diferentes subjetividades, conforma dois grandes movimentos unidos, indissociáveis e tensos. No marxismo, a compreensão destes movimentos é feita por meio da dialética e é denominada objetivação.

Lukács desdobrou este movimento em dois conceitos: objetivação e exteriorização (1981, apud GOMES, 2010, p.139):

\begin{abstract}
Cada movimento e cada reflexão do trabalho em curso (ou antes) são dirigidos, em primeiro lugar, a uma objetivação, ou seja, a uma transformação teleologicamente adequada do objeto do trabalho. A execução desse processo comporta que o objeto, antes existente apenas em termos naturais, sofre uma objetivação, isto é, adquire uma utilidade social. Relembremos a novidade ontológica que aqui emerge: enquanto os objetos da natureza como tais possuem um ser-em-si, e o seu tornar-separa-nós deve ser adquirido pelo sujeito humano por meio do trabalho cognoscivo, ainda que isso, através de muitas repetições, torne-se pois rotina, - a objetivação imprime de modo direto e material o ser-para-si na existência material das objetivações; este faz parte, agora, da sua constituição material, ainda que os homens que nunca tiveram contatos com aquele específico processo produtivo não sejam capazes de percebê-la. Todo ato deste tipo é, ao mesmo tempo, um ato de exteriorização (Entäusserung) do sujeito humano. (...) É evidente que aqui não se trata simplesmente de dois aspectos do mesmo processo, mas de algo a mais. Os nossos exemplos anteriores mostram que os mesmos atos do trabalho podem e, aliás, sob o domínio de um determinado modo de trabalhar, devem provocar no próprio sujeito divergências socialmente bastante relevantes. E é aqui que vem à tona a divergência dos dois momentos. Enquanto a objetivação é imperativa e claramente prescrita pela respectiva divisão do trabalho e, por conseguinte, desenvolve nos homens, por força das coisas, as capacidades a ela necessárias (naturalmente que nos referimos apenas a uma média exigida pela economia, na qual as diferenças individuais, também sob esse aspecto, jamais são canceladas completamente; contudo, isso não muda a substância da coisa), o efeito de retorno da exteriorização (Entäusserung) sobre os sujeitos do trabalho é por princípio diversificado (LUKÁCS, 1981).
\end{abstract}

Então, a objetivação e a exteriorização ocorrem ao mesmo tempo, são inter-relacionadas e conformam um mesmo processo. No agir humano, o homem coloca para o exterior algo que era interior ao ser humano na forma de posição teleológica. Antes ou no curso do trabalho, a ação ou a reflexão do trabalho são dirigidos a uma objetivação, quer dizer, o objeto antes existente apenas em termos naturais, pela ação de objetivação do homem, adquire uma utilidade social. O homem, por meio da mediação do trabalho como atividade vital para ele, torna o devir, produto da ação guiada pela consciência, sendo esta a via em que se constitui a relação sujeito-objeto-sujeito a partir da relação teleológica da objetivação e exteriorização. 
Em consequência, a dialética objetivação-exteriorização constitui-se em caminho por meio do qual os homens intervêm no mundo, tornam-se objeto de sua prática e consciência, processo no qual humanizam o mundo e socializam o ser do homem. Então, uma questão posta aqui é que a imagem construída pelo sujeito, embora possua uma fidelidade desejada, não se apresenta como uma fotografia e nem é estática, mas apresenta uma autonomia no processo de formação de um ser social. Incessantemente, o objeto se fixa provisoriamente na consciência e por ser esta dotada de autonomia, passará por reexame a cada nova situação concreta no interior dos atos operatórios humanos, fazendo com que seja confirmada, readequada, transformada, o que constitui um movimento que determina à práxis humana (GOMES, 2010; CODO, 1994).

Deve-se considerar que o desenvolvimento das forças produtivas está atrelado ao desenvolvimento das capacidades humanas, o que não corresponde obrigatoriamente à transformação da personalidade humana, no sentido de uma aproximação, de uma adaptação entre objetivação e subjetividades, desencadeando o processo de alienação. Ao contrário, a potencialização das capacidades singulares pode desfigurar, aviltar a personalidade do homem (GOMES, 2010).

Neste ponto, podemos retomar a reunião com a equipe da USF Rubi, sobre a Saúde Bucal na ESF, onde as ações intersetoriais para resolução de problemas no âmbito da ESF foram delegadas como competência da área médica em detrimento das outras áreas profissionais da saúde presentes na USF Rubi.

[...] RFA Gameleira: isto vem ao encontro com o que o ALM Pinheiro falou sobre medicina de família que acha que ela é a medicina mais apta para resolver demandas de outros setores, estatuto de idoso, assistência social. (Reunião sobre Saúde Bucal, 08/02/2011).

Isto mostra que somos constantemente atravessados por instituições, neste caso, o modelo hegemônico da assistência centrada na área médica e que pode levar, em alguns momentos, à alienação do processo de trabalho da equipe, porque limita os cuidados à saúde a uma ação apenas, que é tão necessária como as demais áreas da saúde.

Por outro lado, em outra situação, o caso da família do Sabiá Laranjeira mostra que, a partir de um determinado ponto das reuniões, a equipe toma o caso no sentido de compreender a dinâmica familiar, o seu modo de vida, para em seguida elaborar projetos terapêuticos conjuntos e com foco na família. Deste modo, pode-se concluir que para a maioria dos trabalhadores da USF Rubi, a objetivação de seu trabalho passa pela família, pelo 
Sabiá Laranjeira. Esta conformação do processo de trabalho proporciona a estes trabalhadores se reconhecerem nos desdobramentos do cuidado realizado, o que gera satisfação.

TO Araça: família i da micro área s, né, não sei se a gente poderia aproveitar que a psicologia está aqui, não sei se a gente vai discutir na reunião de família ou na reunião de psiquiatria.

PS Macieira: acho que poderia discutir sim, acho que dá para a gente, até para a equipe, ficar a par, né, do que está acontecendo.

TO Araçá: eu vim para isso, para ampliar um pouco. [silêncio]

TO Araçá: na verdade eu vim para cumprir minha função, acho que houve uma pressão na equipe na semana passada, de uma das pessoas da família, da filha, de como ela está sendo tratada. Então, a gente poderia conversar e falar.

ACS Nogueira: o CD Buriti também queria discutir. Família i da micro área $\mathrm{s}$ [silêncio]

ACS Nogueira: pai de 50 e ... me ajuda ACS Ébano.

ACS Ébano: 52 anos, vai fazer 52.

Por outro lado, quando o trabalho é direcionado segundo a lógica hegemônica, pautada apenas por questões orgânicas e pela medicalização, isto faz com que a formatação do processo de trabalho caracterize-se por uma fragmentação do cuidado à saúde. $\mathrm{O}$ desdobramento, produtos do cuidado em saúde fragmentado, ao serem percebidos pelos trabalhadores, pode gerar uma contradição, em função de não se reconhecerem nos produtos gerados. Em síntese, gera um processo de trabalho alienado, fragmentado, e que no cotidiano, pode ser expresso pelos sentimentos cotidianamente relatados pelos trabalhadores como sofrimento, frustrações e estresse.

O trabalho é a atividade que se destaca no movimento dialético do homem no mundo, sendo a forma fundamental da objetivação-exteriorização, pela sua característica ontológicaconstituidor do ser social, do gênero humano. Trabalho entendido como produção da vida humana, atividade de objetivação-exteriorização humana, por meio do qual o homem produz os meios necessários à satisfação de suas necessidades naturais, espirituais, culturais, simbólicas e outras. É pelo trabalho que o homem imprime no mundo as marcas do seu devir. O homem, por meio do trabalho e da sua relação dialética com a natureza, ao mesmo tempo em que humaniza a natureza, humaniza a si, como parte da natureza, subordina a existência da espécie ao desenvolvimento do gênero; subordina o ser natural ao ser social, colaborando para o recuo crescente da barreira natural e fazendo com que seu ser torne-se tendencialmente mais humano.

Codo (1994) nos diz que o homem se hominiza, quer dizer, o homem se constrói como homem, por meio do trabalho. A história é sinônimo de evolução do trabalho dos homens, 
sendo que a nossa herança e nossos projetos se materializam por e pelo trabalho, constituindose em ponto de intersecção entre passado e futuro. O homem é o único animal que produz sua própria existência. Somos o que somos em função do trabalho, ele é o nosso modo de ser. Esta conjuntura faz do homem um ser histórico e fazer história significa objetivar-se no produto, ser fora de si, deixar a própria face na natureza. Se o homem se projeta no seu trabalho, o que ocorrer com ele se produzirá de alguma forma no homem.

Aqui também há o sentido de provisoriedade, ou seja, os homens não são; os homens estão sendo, pois se fazem, produzem-se permanentemente como expressão da autoconstrução humana em seu processo de intervenção sobre o mundo com vistas a garantir sua existência, pautada pela inter-relação, na qual se tem uma ação permanentemente transformadora e inovadora do sujeito sobre o objeto e do objeto sobre o sujeito (GOMES, 2010).

Podemos exemplificar retomando o caso do Sabiá Laranjeira que, ao procurar o serviço de urgência da UBDS Citrino, queixou-se do dente fraturado ao dentista. O dentista poderia objetivar sua ação centrada na recuperação do dente fraturado, restaurando-o, em função das subjetividades presentes naquele momento: o compromisso profissional em reabilitar dentes, o prazer do trabalho artesanal proporcionado pela restauração, o sentimento de um dever a ser cumprido, um estímulo pelo desafio que o caso apresentava, um caso muito interessante para os alunos atenderem, o sentimento de fraternidade ou caridade, a idealização de um sorriso bonito. Mas, a objetivação parece ter sido no sujeito, nas condições em que o Sabiá apresentava-se naquele momento: confuso, com dificuldades de relacionar-se, sem documentos, sozinho e abandonado. Estas condições acionaram no cirurgião-dentista outras questões, como família, organização familiar, proteção da família, autonomia, possibilidades de transtornos mentais.

Neste contexto, os serviços de saúde, a princípio o homem-profissional de saúde, objeta seu trabalho no homem-usuário. O homem-profissional se projeta no seu trabalho e o resultado de seu produto retorna para o homem-profissional. Esta relação faz com que a práxis nos serviços de saúde seja ao mesmo tempo muito rica, prazerosa, criativa, mas que pode ser, também, repetitiva, densa, exaustiva, sofrível e frustrante.

Embora a objetivação e exteriorização apresentem-se indissociáveis, em alguns momentos da história, ocorreu a prevalência de um deles sobre o outro. Assim, na antiguidade, a subjetividade estava mais presente do que a objetivação, ou seja, a marca da personalidade de cada indivíduo em suas objetivações era mais explícita. Atualmente, o processo de divisão do trabalho, socialização da produção, mecanização dos processos produtivos, causam uma homogeneização maior dos processos de trabalho, caracterizando 
uma desantropomorfização dos processos produtivos. As subjetividades estão presentes, mesmo nos processos produtivos mais mecanizados. Porém, a sua visibilidade ou o reconhecimento pelo sujeito operante é, muitas vezes, quase nulo (GOMES, 2010).

Consideramos que as diretrizes para organização do processo de trabalho nas unidades da ESF (BRASIL, 1997; 2000) possuem potencialidades, no sentido de propiciar que as subjetividades dos trabalhadores de saúde possam estar presentes no desenvolvimento de ações de saúde. Isto é possível em função do vínculo que pode ser criado entre sujeito/usuário e sujeito/trabalhador e da delimitação de um território que estabelece uma população a ser cuidada estável, reconhecida e com possibilidade de criação de identidade com a unidade de saúde. Além disso, destacam-se o trabalho em equipe interdisciplinar voltado para a família, a periodicidade de visitas e consultas na unidade, bem como o equilíbrio entre número de usuários e trabalhadores da unidade. Este contexto possibilita desenvolver um processo de trabalho, cuja alienação possa ser reduzida, gerando uma satisfação maior por parte dos trabalhadores e proporcionando ações melhor qualificadas.

Se compararmos este processo de trabalho com as características de atendimento das unidades de saúde tradicionais e serviços de urgência e emergência, é possível imaginar, ou mesmo, constatar, rotatividade de usuários, atendimento pontual centrado na queixa imediata e tecnicista por natureza, com práticas baseadas na medicalização. Isso gera um processo de trabalho que sugere uma linha de produção: atendimento rápido, com possibilidades de criação de vínculo limitadas e desenvolvimento de ações fragmentadas com relação ao cuidado em saúde. Este processo de produção pode levar os seus trabalhadores a não se reconhecerem nos desdobramentos de suas ações de trabalho, gerando um grau de alienação maior. Como resultante, podemos ter trabalhadores insatisfeitos, abstenção ao trabalho e ações menos qualificadas de saúde.

[...] EF Aroeira: No SUS ainda tem este modelo, né, da atenção centrada na doença, enquanto a gente tenta mudar isso, o difícil conviver com os dois modelos, por que eu saio daqui e vou no pronto atendimento, e lá é literalmente isso, modelo assistencial centrado na doença, baseado na queixa de quem procura, livre demanda, as pessoas só vão atrás para resolver problema, né, é a doença, é a doença, é uma demanda sem fim, desorganizada, acho que para a gente trabalhar com o conceito ampliado, a gente vai passar por isso, né, realmente organizar, mas não é fácil, é a gente explicar e a população entender, a gente está contra um modelo que é muito forte. (Reunião sobre Saúde Bucal, 08/02/2011).

Esta distinção entre os processos de trabalho relatados, também pode ser vislumbrada na Saúde Bucal. Anterior ao início das atividades das USF, o processo de trabalho da 
odontologia na UBDS Citrino limitava-se ao atendimento cirúrgico-restaurador, condicionado pela realização de procedimentos, tais como restaurações, raspagens periodontais, extrações, exames clínicos, medidas preventivas e outros. A objetivação do cirurgião-dentista era a recuperação do dente, gengiva, tecidos moles, boca, que conformava um trabalho fragmentado com relação ao cuidado à saúde, restrito ao ambiente do consultório odontológico. Este caminho levava à repetição de procedimentos, que sugere um processo de massificação do usuário e do profissional.

Logo no início das atividades nas USF, a inserção da Saúde Bucal na equipe e a introdução de dispositivos que possibilitaram modificar a objetivação do cirurgião-dentista, tendencialmente para o sujeito e não mais para a boca, levou à ampliação dos meios de trabalho para além dos procedimentos reparadores, incluindo as discussões de casos de família, visitas domiciliárias, reuniões de discussão de casos de psiquiatria, consulta e grupo de Saúde Bucal, ações coletivas com a comunidade. A ampliação do recorte do objeto do processo de trabalho, em função da criação de um campo interdisciplinar de práticas e de responsabilização em torno do cuidado à saúde das famílias, proporcionou a compreensão no modo de viver da comunidade, das famílias e dos sujeitos. A possibilidade do diálogo presente na consulta de Saúde Bucal, marcada pela alteridade, abre caminho para a intersubjetividade do sujeito/profissional e sujeito/usuário no cuidado à Saúde Bucal.

Portanto, as modificações do processo de trabalho relatadas levaram à condição de um menor grau de alienação, pois a boca foi antropomorfizada. O cuidado à saúde deixa de ser fragmentado, porque passa a ser compartilhado, construído, na maioria das vezes, com o conjunto dos profissionais da equipe. Então, neste processo de trabalho, o cirurgião-dentista, enquanto homem-trabalhador, pode se reconhecer nos desdobramentos da prática coletiva da saúde, voltadas para os homens/usuários.

De modo semelhante, a inserção da Saúde Bucal no cotidiano da equipe, compartilhando os espaços comuns das reuniões de equipe administrativa e discussão de casos de família, registrando em prontuário de saúde único, participando nos eventos da unidade e de educação permanente, levou a uma aproximação por parte dos profissionais não dentistas com conhecimentos e práticas relacionadas à cavidade oral, tornando-a mais presente no cotidiano da equipe. Assim, o processo de trabalho desenvolvido no cuidado à saúde passa a contemplar a cavidade oral nos movimentos de objetivação e produção de subjetividades.

[...] TO Araçá: faz uns quatro anos que a TO está aqui, nunca tinha trabalhado com dentista e é a primeira vez que trabalho com um dentista de forma tão perto. Ter a odontologia na saúde pública. Lembro que em uma reunião foi falado sobre a 
saliva e que para mim, o excesso é um problema e para a odonto a falta é um problema. Mas para mim era uma coisa nova. Só desperta enquanto profissional quando de fato compartilha. O quanto temos compartilhado as discussões de organização do serviço e os casos de família? Muitas vezes estamos mergulhados na rotina e o que tem importância para crescer, enquanto equipe, para poder acrescentar, acaba não sendo feito. A gente explica teoricamente. Mas em geral, quem se aproximou da TO, vive e sabe encaminhar e conhece a TO. É quem viveu com um profissional deste na equipe. De eu contar é muito longe. Não sabe exatamente o que eu faço. Precisa criar uma parceria, trabalhando comigo, se aproximando e eu também abrindo para isso. Fico pensando nestas questões, o quanto eu posso conhecer e o que eu preciso saber, o que eu posso como técnico, o que eu posso contar e colocar. (Reunião Administrativa de 20/08/2010).

RMFC Jasmim fala que o sofrimento pode ser uma dor social, o não uso de uma prótese, a falta do dente. TO Araçá traz a história de uma paciente que não queria frequentar outros atendimentos por estar sem próteses. CD Buriti traz a questão das percepções diferentes entre pessoas em relação ao sofrimento odontológico. DO Hibisco lembra de uma propaganda de uma criança que está trocando os dentes e fica constrangida pela mudança de cor, e chama a atenção da MD Acácia para a necessidade de estarmos sensível as necessidades, que não sejam apenas sofrimento (Reunião Administrativa de 03/09/2010).

Assim, compartilhando os espaços de discussão na USF Rubi, a Saúde Bucal torna práticas e saberes desta área presentes para os trabalhadores-profissionais. Isto acaba mobilizando a equipe no sentido de que haja uma aproximação com a Bucalidade, podendo incorporá-la na objetivação do cuidado à saúde.

\subsection{A Saúde Bucal na arena da atenção básica em saúde e da ESF}

Uma das ofertas efetivada à equipe foi discutir a possibilidade de ofertar vagas para atendimentos eventuais na USF Rubi, como porta de entrada para acolher pacientes que tivessem alguma necessidade de atendimento imediato, mas que não configurasse urgência.

[...] EF Aroeira: no caso dessa paciente que ele está falando, ela me ligou, ela veio aqui e ai ela teve uma intercorrência comigo e ela não pode vir, ela conversou com a EF Aroeira, aí ela me ligou, explicou, falou, falou, falou e não falou que era dor de dente, falou que era uma dor miofascial que estava incomodando demais, bom, então é pra estar aqui amanhã, você vem para conversar, ainda coloquei lá, expliquei, coloquei na agenda o que é que ela me relatou, daí a dizer que ela teve ... porque o paciente chega aqui e fala o que ele bem quer ainda mais pelo telefone, então eu vejo que a gente está ali se ele quer falar a verdade ele fala se ele quer inventar alguma coisa pra chegar aonde ele quer chegar ele inventa, daí cabe a nós saber se é verdade ou não. (Reunião Administrativa - 05/02/2010)

CD Buriti: então, ela ficou e ela queria o atendimento e eu fiquei sem jeito, eu entendi o problema dela, eu a entendi, realmente ela precisava de um atendimento e eu acabei fazendo uma consulta normalmente, ela está com disfunção temporomandibular, perdeu o pai há pouco tempo, passou por um período de estresse e isso faz parte do quadro, precisava de orientações, ela queria saber o que era, ela saiu sabendo o que é, hoje ela vai lá no UBDS pra receber um atendimento que é mais específico, nem tem usado a medicação que ela mantinha em casa pra dor...;foi importante? Foi, eu achei que foi necessário, então precisaria ver, é legal ter um horário de eventual? Como que agente poderia tentar organizar isso? Ontem eu fiquei em dúvida (Reunião Administrativa - 05/02/2010) 
Para os pacientes que procuram a USF Rubi com uma necessidade de atendimento de urgência há um fluxo definido. Com relação a demandas da população que necessitem de atendimento imediato, mas que não caracterize urgência, não havia um espaço para acolher esta demanda. Entretanto, a maior expectativa da equipe, pelo fato de desconhecer a rotina de atendimento, era com relação aos agendamentos de pacientes que faltaram em uma consulta e desejavam retomar o tratamento.

[...] EF Aroeira: eu não sei o que acontece, porque assim, começa na terça, quarta, e o pessoal começa a me procurar, "eu estava em acompanhamento e eu precisava de falar com o Dr. também, eu marco uma hora será que ele fala comigo? Olha ele já tem um monte de gente agendada, eu não sei, você vem aqui na quinta feira se você tiver um tempo? Porque eu não sei, é uma coisa muito específico odontologia, é diferente de eu chegar e falar com a MD Acácia, no caso da odonto, esta em acompanhamento aconteceu isso, isso e isso o que é que eu faço? Então a gente fica numa saia justa, então vem e espera pra vê o que ele te fala, não tem uma alternativa, porque a gente sabe se é uma urgência já existe, agora esta em acompanhamento o paciente tem dúvida ou quer alguma orientação é difícil eu falar "ó é só no teu horário", então as vezes é isso que prende a gente e eu peço pra vir mesmo, "olha vem, aguarda, ele vai sair vocês falam com ele". (Reunião Administrativa 05/02/2010)

A recepção das unidades é, na maioria das vezes, o local do primeiro contato com os usuários, tornando-se o depositário das demandas de saúde dos usuários que procuram a unidade. Um local, portanto, onde a atitude de acolhimento pode ser construída com maior frequência, embora o acolhimento seja um atributo de todos os profissionais das unidades de saúde.

Sá et al (2009) dizem que a atitude de acolhimento das demandas dos usuários está na dependência do objeto do processo de trabalho dos trabalhadores, ou seja, o que será transformado por sua ação intencional. No caso da recepção de uma unidade de saúde, referese à concepção do trabalhador sobre saúde e necessidade de saúde, no ato do encontro com o usuário. Os autores concluíram que, na unidade pesquisada, a recepção é o locus de expressão de necessidades de saúde dos usuários. Porém, em decorrência da fragmentação do processo de trabalho da equipe, o que se materializa na recepção causa um afastamento entre a capacidade de antever o produto final do trabalho e o que se realiza de fato. Esta situação torna limitada a oferta de procedimentos, uma vez que estes serão a objetivação estrita do recorte das necessidades de saúde dos usuários, tomadas numa dimensão reduzida de problema de saúde e, neste sentido, determinado pela visão biológica do processo saúde-doença. Em consequência, o trabalhador concentra suas ações nas tecnologias duras, ou seja, normas, estruturas organizacionais, máquinas, e leves-duras, tais como os saberes estruturados que operam no processo de trabalho em saúde, em detrimento das leves (MERHY, 2002), que representam a construção das relações de vínculo, acolhimento e gestão, estabelecidos em 
encontros de diferentes componentes da equipe. Assim, perde-se a oportunidade de estabelecer um diálogo sujeito/profissional-sujeito/usuário.

Ao considerarmos que um dos meios do processo de trabalho em saúde é conhecimento adequado a ação, foi sugerida a elaboração de critérios para orientar o fluxo dos usuários na unidade com relação à atenção à Saúde Bucal, especificando os tipos de situações dos usuários e formas de resolução (Apêndice 3). Uma das propostas foi oferecer vagas para atendimento eventual na USF Rubi, a qual foi elaborada no sentido de ampliar as possibilidades de acolhimento. Porém, isto não correspondeu às expectativas da equipe, pois sua demanda era ter um horário para resolver os problemas dos pacientes que haviam faltado em algum agendamento e gostariam de retomar o seguimento, necessitando de um novo agendamento. Para satisfazer essa demanda, contudo, parece não ser necessária uma consulta e, adicionalmente, deve-se considerar que a oferta de consultas de Saúde Bucal é limitada.

\begin{abstract}
AE Cambuí diz que é uma concentração de informação, muita informação, é mais uma coisa para a recepção, vai parar na recepção, tem paciente tranquilo e irritado, a recepção é a porta de entrada, vai ficar para enfermagem resolver, o cartão na mão ajudaria. É dito que marcar grupo é fácil, e propõe-se que os agendamentos de retornos fossem realizados nos dias de atendimento da odonto ou por telefone. A equipe percebe que o número de reagendamentos é pequeno, apenas os faltosos. Reunião Administrativa do dia $12 / 11 / 2011$
\end{abstract}

$\mathrm{O}$ atendimento de urgência recebeu atenção pela equipe nos quatro momentos de discussão, sempre trazido como dúvida a respeito de seu funcionamento, mesmo que tenha sido objeto de esclarecimentos e informações, e seu funcionamento seja anterior à criação das USF. Este interesse, conforme dito anteriormente, pode estar relacionado ao aparato tecnológico e à característica cirúrgico-restauradora da prática do dentista no atendimento de urgências.

Embora o serviço de urgência possua a mesma rotina de funcionamento nos últimos seis anos, ainda há dúvidas e confusões a respeito do seu funcionamento, sendo necessária uma nova intervenção no sentido de esclarecer o seu funcionamento.

[...] DO Hibisco: eu só queria deixar bem claro a questão da urgência, por que a gente está tendo alguns problemas em outros núcleos também, né, sobre a informação que é dada para o paciente, então, se ele tem dor, ele pode procurar o UBDS a qualquer momento de funcionamento, a questão é, que até para a urgência durante o dia tem vaga, o eventual aqui não tem, também, DO Baobá: tem.

MD Acácia: tem.

DO Hibisco: lá também tem, por que os dentistas tem um número de agendados, então pode ser que o paciente chegue lá, e ele não possa ser atendido naquele momento, aí ele tem duas opções, ele pode retornar no UBDS as cinco horas ou ele pode ir ao Pronto Socorro Central. Quer dizer, avalia-se assim, o tamanho, a gravidade também da urgência, se for dor, ele é medicado para esperar se ele quiser, ou é medicado para ir para o Pronto Socorro Central, quer dizer, o alívio da dor ele vai ter mesmo que seja por medicação, tá. Mas, às vezes ele não vai poder ser atendido. (Reunião Administrativa 20/8/2011). 
A equipe da USF Rubi demonstrou tendência em considerar o serviço de Saúde Bucal da unidade como uma área de saúde autônoma, uma especialidade, dotada de especificidades e regras próprias, à semelhança da inserção das equipes de Saúde Bucal nos modelos das unidades de saúde convencionais. Parte da equipe também o reconhece como uma especialidade, não somente por ter especificidades, que não são vistas como intransponíveis ao trabalho, mas por gerar mais trabalho aos profissionais da equipe.

[...] EF Aroeira: mas se é um paciente que está passando só na odonto e não está passando na rotina não tem como agente saber, mas os que vem e muda o telefone agente tem alterado lá no hygea. (Reunião Administrativa - 05/02/2010)

O CD Buriti explora as condições em que os usuários possam procurar a unidade e ressalta a situação do paciente cordeiro, em vista da possibilidade do paciente vir para marcar um horário para atendimento odontológico, ter um agravo a Saúde Bucal que necessite de atendimento imediato, mas por não expressar a sua necessidade, acaba simplesmente seguindo o fluxo do atendimento. MD Acácia diz que esta atribuição é exclusiva do dentista. CD Buriti diz que por meio de perguntas outros profissionais poderiam buscar queixas e sofrimentos nos usuários. MD Acácia fala da separação do serviço médico e odontológico. ALE Cipreste ajuda nesta separação, dor médica da dor odontológica. TO Araçá e DO Cerejeira trazem a ideia que quando uma pessoa possui um problema odontológico procura diretamente a odonto, mas há quem procura do ponto de vista da prevenção. (Reunião administrativa 03/09/2011)

No entanto, outros estudos têm demonstrado que os obstáculos no trabalho em equipe podem residir em outros aspectos. Soares et al (2011), realizando uma revisão das publicações a respeito da atuação da Saúde Bucal na Estratégia Saúde da Família no período de 2001 a 2008, destacaram, dentre os pontos negativos abordados nos artigos, a falta de atividade de planejamento, programação e avaliação e obstáculos na relação entre os diferentes sujeitos.

Souza e Roncalli (2007) estudaram o modelo assistencial das equipes de Saúde da Família que possuíam equipe de Saúde Bucal no Estado do Rio Grande do Norte. Os autores verificaram, com relação à organização do trabalho, que, embora as equipes realizassem reuniões para avaliação e planejamento das ações de saúde da unidade, a interação entre as disciplinas ficou limitada à multidisciplinaridade, ou seja, o cuidado à saúde mantinha-se fragmentado.

Araújo e Rocha (2007) discutem o desenvolvimento de um processo de trabalho em equipe inter/transdisciplinar como elemento fundamental para efetivação dos objetivos da Estratégia Saúde da Família, dentre eles, a modificação do modelo assistencial médicocentrado. Destacam que esta mudança está diretamente relacionada à forma de cada trabalhador produzir o cuidado, assim como aos diversos modos de agir dos profissionais entre si e com os usuários. O cuidado em saúde e a interação entre si oferecem possibilidade de que os atores utilizem todo o seu potencial criativo e criador na relação com o usuário, para em seguida, juntos, realizarem a produção do cuidado. 
A perspectiva da ação conjunta dos trabalhadores, onde haveria a possibilidade do projeto terapêutico ser fruto da junção e negociação dos saberes e ações específicas dos distintos trabalhadores, considerando a organização de um processo de trabalho que possibilite ao conjunto processos de autoanálise e autogestão, implica considerarmos as dificuldades e singularidades inerentes a este processo em todas as dimensões.

Nesta direção Baremblitt (2002) afirma que toda organização requer, para seu pleno funcionamento, certa divisão do trabalho, hierarquias e gerências, e ao discutir o processo de autoanálise e autogestão diz:

[...] Mas a existência de hierarquia não implica diferença de poder; não equivale a privilégio ou arbitrariedade na capacidade de decidir. Implica apenas uma certa especialização em algumas tarefas, porque estes dispositivos estão feitos de tal maneira que as decisões de fundo são tomadas coletivamente. Em todo caso, os quadros hierárquicos não são mais que a expressão da vontade consensual. São executores. Mas não são executores do mandato das elites mediatizado por organismos burocráticos, por correias de transmissão. Na autogestão os coletivos mesmos deliberam e decidem (BAREMBLITT, 2002, p. 19).

Esta consideração a respeito da hierarquia nas equipes da ESF também diz respeito às relações entre os saberes e a construção de práticas interdisciplinares. Na relação interdisciplinar, considerada pelo Ministério da Saúde (BRASIL, 1994, 2000b) como um dos pilares da Estratégia Saúde da Família, é esperado que uma das disciplinas assuma a função de coordenação entre um conjunto que esteja implicado em uma problemática. Esta coordenação é definida pela proximidade com a temática do campo do problema em pauta, exercendo as funções integradora e mediadora da circulação dos discursos disciplinares e, principalmente, coordenadora do campo disciplinar (ALMEIDA FILHO, 1997). Portanto, a coordenação das relações interdisciplinares não é um posto fixo na equipe, mas um lugar a ser preenchido por um especialista que possui um saber mais próximo do campo problemático em discussão. No caso das equipes da ESF, esta coordenação pode ser exercida pelo médico, enfermeiro, agente comunitário da saúde, dentista, auxiliar de enfermagem.

Esta questão nos remete à concepção do objeto de trabalho no cotidiano de uma USF, onde os usuários dos serviços podem ser reconhecidos como detentores de necessidades de saúde correspondentes ao recorte do objeto idealizado pelo trabalhador. Sá et al (2009), estudando a percepção do trabalhador no processo de trabalho na recepção de uma unidade de saúde, citam a consulta médica como um dos principais focos da recepção e a recepção como parte do processo do trabalho médico. Os autores evidenciam que o processo de trabalho aparece centrado em procedimentos, não havendo espaço para subjetividades do usuário e do trabalhador. Sá et al (2009, p. 466) continuam dizendo que: 
Este arranjo de saberes e combinação de recursos para operacionalizar um certo projeto, vislumbram uma finalidade, e observam coerência entre os elementos constitutivos do processo de trabalho com a diretriz política do projeto assistencial. Se o trabalhador ficar alijado da finalidade, pode ser alvo fácil de manipulação, ou reprodutor de políticas, afastando-se do compromisso e da responsabilização pela saúde dos usuários, sem a preocupação com o desenvolvimento da autonomia dos mesmos.

Por outro lado, Faccin, Sebold e Carcereri (2011), investigando a interação da Saúde Bucal em equipes de Saúde da Família no Estado de Santa Catarina, observaram o desejo dos profissionais não dentistas em construir uma interação com os saberes de Saúde Bucal. As expectativas dos profissionais não dentista eram direção da resolução das demandas imediatas e em contar com um dentista com características de profissional que não tivesse um perfil de “dentista curador", que se aproximasse ao perfil do enfemeiro. Entretanto, neste estudo, os dentistas não se reconheceram preparados para comporem a interação com a equipe, justificando esta percepção por deficiências na formação acadêmica e na pós-graduação latu senso em torno da atuação em equipe.

A equipe da USF Rubi reconhece que discutir a Atenção à Saúde Bucal é também repensar a organização do processo de trabalho da equipe com relação à Estratégia Saúde da Família e a integralidade da atenção a saúde.

ACS Nogueira chama atenção para a fala da DO Hibisco no sentido de qual a importância que estamos
dando para a parte de Saúde Bucal de avaliar as condições de Saúde Bucal das pessoas. TO Araçá diz
que está além da Saúde Bucal, o PSF deveria estar olhando para além da rotina, quando se traz a
questão da Saúde Bucal, na verdade estamos discutindo o atendimento da USF. ACS Nogueira fala da
necessidade de olhar o paciente como um todo, olhar a estratégia da Saúde da Família. MD Acácia diz
que não é possível separar. CD Buriti fala que na consulta de Saúde Bucal busca-se olhar para um todo
e exemplifica com o caso de um paciente que não sabia de sua condição de hipertenso e que durante a
consulta e Saúde Bucal foi possível constatar a hipertensão, orientar o paciente, discutir o caso a MD
Acácia, sendo agendado consulta para seguimento médico. Não é uma questão de quantidade, mas sim
de qualidade. As pessoas se referem às vezes com relação ao que é ofertado ou perguntado. DO Hibisco
diz das relações, enquanto nós dentistas também olhamos outros problemas de saúde, buscamos
pacientes nos espaços do USF, realizamos um movimento de oferta de serviços (Reunião
Administrativa de $20 / 08 / 2010$ ). Na ótica do processo grupal, Pichon-Riviére (2005) diz que a didática interdisciplinar parte da premissa de que em cada participante do grupo preexiste um esquema referencial, determinado pelas experiências, conhecimentos e afetos com os quais o indivíduo pensa e age e que adquire unidade no trabalho em grupo. Esta unidade, por sua vez, promove, no grupo, um esquema referencial operativo sustentado pelo denominador comum dos esquemas prévios. Então, a didática interdisciplinar cumpre funções de educar, de despertar interesse, de instruir e de transmitir conhecimentos.

Pichon-Riviére (2005, p. 129) ainda considera que nos grupos operativos interdisciplinares, que é o caso das reuniões administrativas da USF, é possível observar o 
fenômeno de "que o pensamento que funciona no grupo vai desde o vulgar e comum até o pensamento científico, resolvendo as contradições aparentes e estabelecendo uma sequência ou continuidade genética e dinâmica entre um e outro".

Em outras palavras, neste momento da discussão é possível verificar que alguns membros da equipe da USF Rubi reconhecem que a discussão da organização da Saúde Bucal na unidade passa pela discussão do seu processo de trabalho, segundo os princípios da Estratégia da Saúde da Família.

A equipe da USF Rubi realiza um movimento no sentido de ampliar o recorte do seu objeto do processo de trabalho, reconhecendo as necessidades de cuidado que vão além do recorte biológico. Além disso, demonstra responsabilização pela demanda apresentada pelo usuário e aciona novas ferramentas para o cuidado em saúde.

CD Buriti pergunta qual o problema que devemos trabalhar, quais perguntas devemos fazer para
detectar problemas de Saúde Bucal, relacionadas a queixa, sinais e sintomas. O que poderíamos fazer
para ampliar um pouco esta visão. RMFC Jasmim relata um caso de desdentado, a dificuldade de
trabalhar com uma prótese, a partir da queixa de um paciente, sentiu responsável em lidar com esta
questão por não ter outro profissional Dentista na unidade, examinou e achou engraçado pela falta de
habilidade e a responsabilidade com o caso (há risadas). CD Buriti chama atenção para as condições de
câncer bucal, diagnósticos tardios, mesmo com o paciente tendo passado por diversos serviços. DO
Hibisco, chama atenção para o fato de RMFC Jasmim ter se sentido responsável, ter lidado com a
situação, acolhido e buscado uma solução com os instrumentos que tinha naquele momento. (Reunião
Administrativa de 20/08/2010).

Em um movimento pendular, a equipe volta a limitar o seu objeto de trabalho nas questões biológicas das necessidades de saúde, na demanda espontânea e atribui à população a dificuldade em ampliar a prática de saúde, uma vez que esta não aceita o trabalho dos generalistas na saúde. Mas, há um avanço no sentido da responsabilização, onde o médico assume a medicalização como forma de atenuar o sofrimento dos usuários nos casos de urgência de origem odontológica.

FI Salgueiro traz a questão dos usuários perceberem a unidade de saúde da família como um centro de especialidade, não vendo a equipe como um local em que acompanha os usuários de uma forma mais ampla. ACS Nogueira diz que os usuários não entendem mesmo a saúde da família. MD Acácia diz que alguns pacientes querem o dentista e não entende a questão do generalista, mas que é possível verificar uma necessidade de dor e prescrever um anti-inflamatório ou analgésico. A maioria entende a questão do generalista. EF Aroeira também concorda com esta situação em que os usuários não entendem as atividades do generalista (Reunião Administrativa de 20/08/2010).

Shimizu e Reis (2011), ao estudarem as representações sociais entre trabalhadores médicos, enfermeiros, auxiliares de enfermagem e agentes comunitários de saúde em unidades de saúde da família do Distrito Federal, concluíram que a interação com as famílias e a comunidade baseia-se na medicalização. Os autores justificam esta situação em função do aprisionamento dos profissionais aos saberes tradicionais, baseado na racionalidade biomédica, sendo necessário suprir as deficiências de infraestrutura, dentre elas, a principal, é 
a ausência de educação permanente em serviço que possibilite a reflexão do modelo de atenção à saúde e de suas estratégias de cuidado em saúde.

Por outro lado, Faccin, Sebold e Carcereri (2010, p. 1648), estudando o processo de trabalho em USF em um município do Sul do Brasil, verificaram um movimento da equipe no sentido de buscar aproximação com a equipe de Saúde Bucal: "Quando um médico examina os dentes e fala o que está acontecendo como os dentes das pessoas, eu vejo que muitos usuários se surpreendem (Médico_unidade1)”.

No transcorrer da discussão da equipe da USF Rubi, são relatadas duas situações de atendimento em Saúde Bucal e em Terapia Ocupacional, onde os problemas de saúde não são específicos da área, o que acaba exemplificando o contexto do trabalho do generalista na equipe.

CD Buriti traz um exemplo da história de saúde realizada na consulta de Saúde Bucal, onde os pacientes acham que as perguntas se referem apenas aos problemas da boca e acabam não informando sobre as questões relacionadas a problemas de saúde não odontológicos, como no caso a hipertensão arterial. As pessoas procuram o atendimento pensando em encontrar o modelo anterior, o ginecologista, o dentista, um atendimento fragmentado, mas é uma questão para ser trabalhada. DO Cerejeira diz que o nosso papel é orientar e não esperar que vai resolver logo de início. TO Araçá, situa esta questão não como uma informação a ser dada, mas sim uma atitude a ser incorporada a ser exercitada pelos profissionais, exemplifica citando um caso em que informou a paciente sobre as reuniões de equipe, sendo que a paciente ficou preocupado com a sua família sendo discutida por uma equipe e compreender pouco sobre o atendimento por uma equipe. (Reunião Administrativa de 20/08/2010).

Azevedo e Costa (2010), ao investigarem a percepção dos usuários ao acesso na ESF em unidades de Recife, Estado de Pernambuco, destacaram que, do ponto de vista sociocultural, há um despreparo dos profissionais e também dos usuários quanto à organização e execução de ações conjuntas e baixa capacidade de visualizar a perspectiva coletiva da saúde, situada no campo da cidadania. Ou seja, a busca por ações e serviços que resultem no controle da dor, na redução do desconforto ou mal estar e na cura de doenças foi o motivo expresso pelos usuários a procurarem as unidades de saúde, exemplificados pela fala de um dos sujeitos da pesquisa (AZEVEDO e COSTA, 2010, p. 804): "é alguma coisa na boca, ou então nos dentes, na visão também [...] (usuário 18, jovem, frequentador, equipe B)".

Esta perspectiva de consumo imediato e individual do serviço, demostrando que a saúde não é vista e baseada numa perspectiva coletiva e de cidadania, é conformada pela oferta dos serviços em ações de natureza estritamente assistencial curativa e individual. Tratase de uma compreensão do processo saúde-doença-cuidado baseada no modelo biomédico de atenção à saúde (COHN, et al, 2002) e que já foi abordada do ponto de vista do estilo de vida cotidiano. 
Deste modo, a discussão da equipe da USF Rubi demonstra ter potencial para iniciar um trabalho em conjunto com a sua população adscrita e pactuar a construção de um modelo de atenção à saúde pautado no desenvolvimento de projetos de vida, no exercício da cidadania e na construção da autonomia.

Na sequência desta discussão a equipe verbaliza a experiência de trabalhar em equipe, com profissionais diferentes, incluindo o cirurgião-dentista e que a disponibilização de conhecimento de áreas diferentes pode constituir-se em um processo de transformação mútua, dando a conformação de uma relação entre disciplinas na forma da interdisciplinaridade.

[...] TO Araçá: faz uns quatro anos que a TO está na USF Rubi, nunca tinha trabalhado com dentista, sendo a primeira vez que trabalho com um dentista de forma tão perto, de ter a odontologia na saúde pública. Lembro que em uma reunião, foi falado sobre a saliva, que para ela o excesso é um problema, para a odonto, a falta é um problema. Para ela, era uma coisa nova. Só desperta, enquanto profissional, quando de fato compartilha. O quanto temos compartilhado nas discussões de organização do serviço e nos casos de família? Muitas vezes estamos mergulhados na rotina e o que tem importância para crescer enquanto equipe e para poder acrescentar, acaba não sendo feito. A gente explica teoricamente, mas em geral, quem se aproximou da TO, quem viveu e soube caminhar e conhece-la, é quem viveu com um profissional deste na equipe. De falar sobre ela é muito longe, não sabe exatamente o que eu faço. Precisa criar uma parceria, trabalhar comigo, aproximar-se. E eu também abrindo para isso. Fico pensando nestas questões, o quanto eu posso conhecer, o que eu preciso saber, o que eu posso como técnico. O que eu posso contar e colocar (Reunião Administrativa de 20/08/2010).

A complexidade da área da saúde e a busca dos serviços de saúde em contemplar as diretrizes de integralidade, universalidade e equidade do SUS nas ações de cuidado em saúde, apontam para a necessidade proporcionar relações entre as disciplinas de saúde e intersetoriais, na forma da interdisciplinaridade (ARAÚJO e ROCHA, 2007; GOMES e SILVA, 2011; TEIXEIRA, 2006; SOUZA e RONCALLI, 2007).

A interdisciplinaridade pode gerar uma relação de reciprocidade, de enriquecimento mútuo e gerar aprendizagem mútua (ALMEIDA FILHO, 1997). Trata-se de um movimento processual que aparenta ser determinada pelo sujeito da investigação ou pelo objeto investigado, mas na realidade, é determinada pelos aspectos processuais da atividade pedagógica científica (PAVIANI, 2008).

Paviani (2008), ao discutir as ações interdisciplinares na intervenção profissional, diz que o profissional, para intervir na realidade, busca conhecimento em diversas áreas e não apenas em uma determinada ciência ou disciplina e esta interação é feita de forma espontânea e intuitiva.

A interdisciplinaridade é condição básica para uma formação profissional flexível e adequada para o exercício de novas profissões. Uma área de conhecimento tende a se constituir a partir de certa autonomia teórica. A atuação profissional, dentro de padrões 
elevados de formação científica, depende da elaboração de métodos adequados de intervenção e da busca e articulação de conhecimentos em mais de uma área teórica. Assim, a formação profissional requer ação interdisciplinar: primeiro, na aquisição de conhecimentos, na sua formação científica e intelectual; em um segundo momento, na aplicação de conhecimentos na resolução de problemas ligados à profissão (PAVIANI, 2008).

Com relação aos cursos superiores, Paviani (2008) relata que a formação de especialidades profissionais, pode ter como base uma cultura científica unitária, integrada, havendo um leque amplo de disciplinas que dão conta dos conhecimentos teóricos atualizados e anteriores à sua possível aplicação. Por outro lado, alguns cursos tendem a aproximar os conhecimentos teóricos e os conhecimentos práticos, ignorando as possíveis formas de interdisciplinaridades com outras áreas de conhecimentos.

A experiência da construção da interdisciplinaridade pela equipe da USF Rubi resgata a sua relação com o processo de ensino em serviço.

DO Hibisco relata as alterações com a formação acadêmica da área da odontologia, uma vez que os
alunos comentam que os pacientes falam de coisas que não são específicas, e não sabem como lidar
com aquilo, e que na verdade o aluno não é obrigado a saber, mas que tem que pegar aquilo, a
responsabilidade é dele, como a RMFC Jasmim disse. Com o tempo e a convivência poderemos
construir isso. Lembra, que dos modelos de interdisciplinaridade, que a presença do profissional das
diversas áreas é importante, que não basta compartilhar texto, livros, conhecimentos das diversas áreas
que a gente tem, mas que ela é construída com a presença do profissional. Uma coisa é pegar um texto
da Saúde Bucal e ler e outra coisa é a gente poder estar vivenciando esta situação. CD Buriti, diz que
estas situações dos alunos com relação ao outros problemas de saúde é compartilhado pelos alunos com a
equipe, eles sentem melhor, compreendem melhor aquele problema, se situaram melhor, por que na equipe
foi possível compartilhar, ver várias visões, ver uma questão histórica. MD Acácia diz que os usuários
olham para gente como profissional de saúde não interessa o que a gente é, qualquer um de nós e dá o
exemplo de um aluno que não sabia o que fazer por uma demanda social de um casal. (Reunião
Administrativa de 20/08/2010).

Watanabe (2007), ao discutir as mudanças curriculares no curso de Odontologia da Faculdade de Odontologia de Ribeirão Preto/USP, relata que na década de 70 surgiram as propostas de ensino extramuros, que tinham o objetivo de proporcionar aprendizagem junto à população, por meio da prestação de serviços de "saúde comunitária", mas também de responder a um questionamento a respeito do entendimento da saúde dos indivíduos sem a dimensão da vida em sociedade, uma vez que o campo das práticas era restrito à Universidade.

A criação do SUS e os esforços para sua implementação e a aprovação das Diretrizes Curriculares Nacionais para os cursos de saúde resultaram em uma aproximação entre o sistema educacional e o de saúde, ao estabelecerem o imperativo de formar profissionais com habilidades e competências para atuarem no SUS (WATANABE, 2007). 
Watanabe (2007) ainda destaca que as Diretrizes Curriculares Nacionais para Saúde reforçam nitidamente a importância do trabalho em equipes multiprofissionais, a compreensão dos problemas de saúde de forma interdisciplinar e assinala a necessidade de adequar a abordagem pedagógica no sentido das metodologias ativas, do desenvolvimento da aprendizagem em cenários múltiplos e a busca pelo equilíbrio entre a excelência técnica e a relevância social.

É neste contexto que a Faculdade de Odontologia de Ribeirão Preto-USP foi convidada a compor um projeto comum junto à Faculdade de Medicina de Ribeirão PretoUSP e a Escola de Enfermagem de Ribeirão Preto-USP para a área de abrangência do CSEFMRP-USP e do Distrito Oeste do Município de Ribeirão Preto, envolvendo Atenção Primária e Programa de Saúde da Família. Isto possibilitou que, na reforma curricular do Curso de Odontologia da FORP-USP, incluídos como campo de estágio para as cinco Disciplinas relacionadas à Estratégia Saúde da Família, os Núcleos de Saúde da Família da área básica do CSE-FMRP-USP. Dentre os objetivos contemplados pelo processo de ensinoaprendizagem vale ressaltar o trabalho em equipe multiprofissional e o desenvolvimento de atividades em conjunto com alunos dos outros cursos de saúde do Campus Ribeirão Preto da USP, a humanização das práticas de saúde, a motivação da população para o controle social e o reconhecimento da saúde como direito de cidadania (WATANABE, 2007).

Assim, os alunos do Curso de Odontologia da FORP-USP estão inseridos nas USFs nos últimos cinco anos, compartilhando com o dentista de cada unidade a referência de Saúde Bucal, quer seja na realização de ações de recuperação, prevenção ou de promoção da saúde quanto nas atividades administrativas e de discussão de casos de família. Deste modo, o aluno tem a oportunidade de vivenciar, junto à equipe, entre outras coisas, a construção de um processo de trabalho em equipe, que busca, por meio do trabalho multidisciplinar, estabelecer uma interdisciplinaridade para a compreensão do processo saúde-doença-cuidado, que não tem a característica de ser linear e homogêneo.

Enfim, na arena da Atenção Básica à Saúde e Estratégia Saúde da Família, há um movimento pendular na percepção pela equipe da inserção da Saúde Bucal na composição do cuidado à Saúde ou restringi-la à assistência odontológica. Este movimento não é exclusivo com a Saúde Bucal e é influenciado pela percepção do trabalho em equipe, pelo recorte do objeto do trabalho e pela alienação gerada na produção do cuidado à saúde. 


\section{6- CONSIDERAÇÕES FINAIS}

Produzir um conhecimento a respeito da construção do campo de saberes e práticas de Saúde Bucal em equipes da ESF constituiu-se na utopia ativa dos pesquisadores deste estudo, em especial deste pesquisador que aqui se coloca.

Assim, nesta investigação, a proposição central está relacionada com o fortalecimento da Atenção Básica à Saúde, da Estratégia Saúde da Família e com a reformulação do modelo hegemônico de Saúde Bucal, centrado em procedimentos cirúrgico-restauradores, ampliando-o para ações de Atenção à Saúde Bucal.

A abordagem do objeto deste estudo foi realizada por meio da pesquisa-intervenção, fundamentada no Movimento Institucionalista, cujo método é a cartografia.

A cartografia possibilitou, a partir do nosso cotidiano na equipe, construir uma trajetória em que houve uma inversão de meto-hodos, para hodos-meta. Em outras palavras, o saber fazer foi construído no percurso da pesquisa, em que cada etapa foi conformada com base no conhecimento produzido pela equipe.

$\mathrm{Na}$ cartografia, todos somos sujeitos e todos somos pesquisadores, no sentido da produção do conhecimento. Então, os pesquisadores encontraram a si mesmos nesse percurso. Por isso, os achados e as conclusões deste estudo são descritos na primeira pessoa do plural.

Ser cartógrafo é acompanhar processos, é perceber os fluxos, movimentos e acontecimentos de cada encontro dos sujeitos da pesquisa. No nosso caso, significou implicar e ser implicado, compartilhar com a equipe as tensões, frustrações, inquietação, sonhos e esperanças.

A aproximação com a cartografia e com o referencial do Movimento Institucionalista constituiu-se em uma nova leitura do objeto de estudo. Inicialmente, interrogávamos, ingenuamente, a respeito dos motivos que levavam a equipe a não compor com a Saúde Bucal nas ações de saúde, atribuindo a motivos relacionados a questões de volume de trabalho e perda de autonomia. Buscávamos respostas e um preceito a ser incorporado por outras unidades, o que poderia levar a uma práxis de Saúde Bucal pela equipe.

A aproximação teórica à cartografia e o transcorrer da pesquisa, possibilitou a compreensão de que o trabalho em equipe de saúde se realiza no e pelo processo grupal. Também se configura em processo de trabalho, em que ocorre produção de cuidado à saúde e geração de alienação. 
O processo de trabalho em equipe na USF Rubi desenvolveu-se por meio de construções e desconstruções, determinadas pelas tensões na unidade entre o modelo hegemônico de saúde, de cunho assistencialista e o modelo de atenção à saúde, com atuação mais ampla. Essa tensão pode ser influenciada pela compreensão dos trabalhadores a respeito do recorte do seu objeto de trabalho, da percepção em torno das características do trabalho em equipe, dos desejos de compor interações de saberes e articulações de ações, da percepção da responsabilização pelo cuidado à saúde da população adscrita e do tipo de comunicação que se estabelece na unidade.

Essa conformação de fatores que puderam ser vivenciados com a equipe, neste estudo, confere ao trabalho em equipe da USF Rubi uma característica de processo e não de status a ser atingido.

Os achados desta pesquisa devem ser considerados como verdades provisórias, pois se referem àqueles momentos da vivência junto à equipe e que hoje podem ser diferentes, em razão dos acontecimentos que são produzidos na equipe e pela característica processual do trabalho em equipe, que é, portanto, histórico. O texto aqui produzido pode ilustrar essa característica de movimento, de processo, pois os capítulos de Introdução e Marcos Teóricos demonstram uma perspectiva mais estática do trabalho em equipe, condicionando seu modo de ser a um status a ser adquirido, entre os tipos integradora ou agrupamento. A partir da Apresentação e Discussão dos dados, é possível verificar a dinâmica da equipe, os movimentos e a processualidade em que ela se produz.

A atuação dos trabalhadores no trabalho em equipe também não apresenta uma homogeneidade, embora estejam inseridos em um processo grupal. Nessa perspectiva, considera-se que nem todos os profissionais da USF Rubi tenham ações semelhantes com relação ao seu entendimento a respeito da produção do cuidado à saúde.

A construção de um campo de saberes e práticas de Saúde Bucal por uma equipe da ESF estão diretamente atreladas ao processo de trabalho que a equipe desenvolve, à percepção do seu objeto de trabalho e à alienação produzida pela produção do cuidado à Saúde.

Foi possível verificar que a equipe da USF Rubi, em alguns momentos, conseguiu desempenhar uma interação de saberes e articulação de ações que convergiram para o cuidado à saúde. Nesses momentos, partiu-se de atitudes individuais, que acabaram mobilizando os demais membros da equipe para a construção coletiva de projeto de saúde e de vida.

Podemos dizer que, nesses momentos, a boca foi antropomorfizada, ou seja, fez parte da elaboração dos cuidados à saúde, na perspectiva da atenção à Saúde Bucal.

Dentre os acontecimentos que compartilhamos, podemos citar a mobilização da equipe em torno do caso do Sabiá Laranjeira, buscando compreender a sua deficiência afetiva, o seu 
sorriso quebrado. A equipe elaborou um projeto terapêutico direcionado para a socialização, o desenvolvimento de cidadania, do auto-cuidado e da Atenção de Saúde Bucal e para o restabelecimento do sorriso.

Assim, nas discussões a respeito da organização da Saúde Bucal, houve um reconhecimento por parte de profissionais não dentistas da qualificação dos agravos à Saúde Bucal como uma questão social, aproximando a questão da perspectiva da Bucalidade. No caso, a ausência de um dente, que não causa dor orgânica, mas que pode acarretar dor social. O relato da experiência do trabalho em equipe gera um enriquecimento mútuo. Por exemplo, há a questão dos volumes de saliva que os usuários apresentam; seu excesso leva preocupação para a Terapia Ocupacional, enquanto para a Saúde Bucal o que preocupa é volume reduzido. Essas são situações que demonstram a interação de saberes e articulação de ações, que potencializam oportunidades para gerar novas práticas de saúde e projetos de saúde e de vida.

Outra situação foi a consulta de Saúde Bucal, dispositivo para o cuidado nesse campo de saberes e práticas, baseada na relação sujeito-usuário e sujeito-profissional. Essa conformação de um espaço para a intersubjetividade recebeu um investimento da equipe da USF Rubi, em torno da sua construção e implantação, demonstrando haver possibilidades para a construção coletiva de práticas de Saúde Bucal.

A USF Rubi também se mobilizou diante dos analisadores "Revendo a agenda da Saúde Bucal da equipe da USF Rubi" e "Discutindo a Saúde Bucal com a equipe da USF Rubi", que foram apresentados pelos pesquisadores e que produziram conhecimento a respeito da Saúde Bucal. Os profissionais se envolveram com a discussão e apresentaram as suas demandas, demonstrando que a Saúde Bucal é uma disciplina que faz parte dos objetivos da equipe.

Com relação ao terceiro analisador, “A equipe e uma de suas famílias: o caso da família do Sabiá Laranjeira", a Saúde Bucal foi reconhecida pelos profissionais da equipe como disciplina que compunha os cuidados à saúde, na interação para compreensão do processo saúde-doença e na articulação das ações para o projeto terapêutico.

Do ponto de vista do ensino, as qualidades do processo de trabalho da USF Rubi conformam um campo de estágio para alunos de cursos de graduação, aprimoramento e residências. Esse trabalho possibilita que os alunos vivenciem o trabalho em equipe e a interdisciplinaridade, o que contribui para a atuação profissional interdisciplinar.

Outros aspectos reforçam o aprimoramento da construção do campo de saberes e práticas de saúde bucal na Equipe de Saúde da Família. Um deles diz respeito à III Conferência Nacional de Saúde Bucal, em que foi referendada a necessidade de implementar um modelo de Saúde Bucal centrado na Atenção à Saúde Bucal, em detrimento do modelo hegemônico, que, 
na Saúde Bucal, é o modelo cirúrgico-restaurador, baseado na recuperação da saúde. Os dados do Ministério da Saúde sobre oferta e demanda de serviços de Saúde Bucal nos últimos oito anos demonstram que, no âmbito nacional, houve ampliação do acesso e redução do número de pessoas que nunca visitaram um dentista, embora, ainda, considere-se distante do adequado. Nessa perspectiva, o deslocamento de parte do horário de trabalho dos dentistas da UBDS para as USFs não configurara restrição de acesso ao atendimento odontológico da população adscrita na UBDS Citrino, levando-se em consideração a ampliação das ações de Saúde Bucal obtida com a mudança do modelo de atenção à saúde implantado.

Parte da equipe demonstrou ter carências a respeito de conteúdos sobre Saúde Bucal, no tocante à sua organização e a respeito de medidas de prevenção e controle de doenças bucais. Essa falta de conhecimento da equipe pode estar relacionada com a não responsabilização pelos problemas de Saúde Bucal, ainda que parcial, uma vez que a boca não é considerada parte do objeto de trabalho, do cuidado à Saúde, embora um dos ACS tenha orientado adequadamente o Sabiá Laranjeira a procurar o atendimento odontológico de urgência, a respeito do horário e alertando-o para a necessidade de estar acompanhado de um responsável. Outro fator que pode contribuir para esse "status" é a dívida histórica construída pela ineficiência ou ausência de políticas voltadas para satisfação das necessidades de manutenção ou recuperação da saúde bucal da população brasileira. Essa dívida social tem mobilizado, na última década, profissionais da área de Saúde e gestores para o resgate da cidadania em relação à saúde bucal, tanto em nível macro como micro. Alguns resultados já foram obtidos, porém os impactos substanciais somente serão percebidos em longo prazo, se esses movimentos continuarem ou forem aperfeiçoados, como se espera.

Também pode estar contribuindo para isso o fato de parte da equipe considerar que o processo de trabalho é organizado com base nas relações interpessoais, o que faz com que o cuidado à saúde seja relegado como objeto de trabalho da equipe. De certa forma, isso também pode gerar nos trabalhadores a falta de percepção da necessidade da interação de saberes para compreender o processo saúde-doença-cuidado e da integração das ações para o projeto terapêutico, levando os trabalhadores da equipe a desenvolverem ações centradas no próprio escopo da disciplina a que pertencem e que são, em alguns momentos, de cunho procedimental.

A conformação do processo de trabalho, determinada pelo limitado recorte do objeto, pode gerar na equipe a compreensão de que a Atenção à Saúde Bucal seja restrita à assistência, aos fazeres procedimentais, à valorização do aparato tecnológico, o que acaba fortalecendo a relação entre oferta de serviços e demanda da população, com base no consumo de serviços de saúde, não contemplando um projeto para o cuidado à saúde. 
Essas características de serviço de saúde estão presentes no modelo hegemônico dos serviços de saúde, centrado na doença e nas ações curativas. A finalidade da ESF é substituí-lo.

A fim de fortalecer a construção das práticas de Saúde Bucal na equipe da USF Rubi, sugerimos à USF Rubi que mantivesse o processo de discussão, baseado na autoanálise e autogestão e que revisse o seu objeto de trabalho, na direção do cuidado à saúde. A USF Rubi já possui certa organização com relação ao processo grupal que desenvolve e já ocorre questionamento a respeito do modelo de saúde praticado pela equipe.

Sugeriu-se, também, que se estreitasse a relação com os usuários para envolvê-los nesse processo de autoanálise e autogestão e da participação na programação das ações da unidade. Dessa forma, abre-se caminho para discutir com a população a modulação entre oferta e demanda de serviços, o que inclui a demanda com relação à Saúde Bucal.

Do ponto de vista do investimento das organizações no plano molar, sugerimos a ampliação dos Centros de Especialidades Odontológicas, com o intuito de aumentar a oferta de serviços e reduzir o tempo de espera para o tratamento especializado, fortalecendo a atenção à Saúde Bucal.

Outra área que necessita ser explorada é o desenvolvimento e/ou a análise de indicadores de saúde bucal que possam avaliar aspectos relacionados não só à assistência, mas, também, à atenção em Saúde Bucal, com o objetivo de estabelecer relações mais detalhadas entre a ocorrência das doenças e seus determinantes sociais, bem como de avaliar o impacto social dos movimentos recentes de mudança no modelo de práticas e serviços de Saúde Bucal.

Ainda restam algumas questões a serem respondidas por futuros estudos a respeito da percepção dos usuários a respeito da saúde, da forma como o usuário percebe as suas necessidades de saúde e estudos que tentem estabelecer um processo de autoanálise e autogestão, com o objetivo de mobilizá-la para uma reflexão a respeito de suas necessidades em função de projetos de vida e de saúde e desenvolver metodologias para aprimorar os levantamentos epidemiológicos das doenças bucais, com o objetivo de estabelecer relações mais detalhadas entre a ocorrência das doenças e seus determinantes sociais. 


\section{REFERÊNCIAS ${ }^{13}$}

AGUILERA CAMPOS, C.; IZECKSOHN, M. Análise do perfil e da evolução dos programas de residência em medicina de família e comunidade no Brasil. Revista de APS, 13 mar. 2010. Disponível em: <http://www.aps.ufjf.br/index.php/aps/article/view/732/307>. Acesso em: 7 out. 2011.

ALBUQUERQUE, O. M. R.; ABEGG, C.; RODRIGUES, C. S. Percepção de gestantes do Programa Saúde da Família em relação a barreiras no atendimento odontológico em Pernambuco, Brasil. Cad. Saúde Pública, Rio de Janeiro, v. 20, n. 3, p. 789-796, maio-jun. 2004.

ALMEIDA FILHO, N. Transdisciplinaridade e saúde coletiva. Ciênc. Saúde Coletiva, Rio de Janeiro, v. 2, n. 1-2, p. 5-23, 1997.

ALTOÉ, S. (Org.). René Lourau. Analista institucional em tempo integral. São Paulo: Hucitec, 2004. 287 p.

ARAÚJO, M. B. S.; ROCHA, P. M. Trabalho em equipe: um desafio para a consolidação da Estratégia Saúde da Família. Ciênc. Saúde Coletiva, Rio de Janeiro, v. 12, n. 2, p. 455-464, apr. 2007.

AYRES, J. R. C. M. Organização das ações de atenção à saúde: modelos e práticas. Saúde Soc., São Paulo, v. 18, p. 11-23, 2009. Suplemento 2.

AYRES, J. R.C. M. Sujeito, intersubjetividade e práticas de saúde. Ciênc. saúde coletiva, Rio de Janeiro, v. 6, n. 1, 2001 . Available from <http://www.scielosp.org/scielo.php?script=sci_arttext\&pid=S1413$81232001000100005 \& \operatorname{lng}=e n \& n r m=i s o>$. access on 24 Nov. 2011. http://dx.doi.org/10.1590/S1413-81232001000100005.

AZEVEDO, A. L. M.; COSTA, A. M. A estreita porta de entrada do Sistema Único de Saúde (SUS): uma avaliação do acesso na estratégia Saúde da Família. Interface (Botucatu), Botucatu, v. 14, n. 35, p. 797-810, dez. 2010.

BALDANI, M. H. et al. A inclusão da odontologia no Programa Saúde da Família no Estado do Paraná, Brasil. Cad. Saúde Pública, Rio de Janeiro, v. 21, n. 4, p. 1026-1035, 2005.

\footnotetext{
${ }^{13}$ De acordo com: ASSOCIAÇÃO BRASILEIRA DE NORMAS TÉCNICAS. NBR 6023:informação e documentação:referências:elaboração. Rio de Janeiro, 2002.
} 
BARBIER, R. A pesquisa-ação na instituição educativa. Rio de Janeiro: Jorge Zahar, 1985. $280 \mathrm{p}$.

BARBIER, R. A pesquisa-ação. Tradução Lucie Didio. Brasília, DF: Líber Livro, 2007. 157 p.

BAREMBLITT, G. Compêndio de análise institucional e outras correntes. Teoria e Prática. 5. ed. Rio de Janeiro: Rosa dos Ventos, 2002. 214 p.

BAREMBLITT, G. Introdução à esquizoanálise. 3. ed. Belo Horizonte: Editora Fundação Gregório Baremblitt/Instituto Félix Guattari, 2010. 147 p.

BOFF, L. Saber cuidar: ética do humano - compaixão pela terra. 9. ed. Petrópolis: Vozes, 2003. $199 \mathrm{p}$.

BOTAZZO, C. A saúde bucal nas práticas coletivas de saúde. São Paulo, 1989. 24 p. Mimeografado.

BOTAZZO. C. Sobre a bucalidade: notas para a pesquisa e contribuição ao debate. Ciência \& Saúde Coletiva. Rio de Janeiro, p. 7-17 v.11, n.1, 2006.

BRANDÃO, C. R. Repensando a pesquisa participante. 3. ed. São Paulo: Brasiliense, 2001. $252 \mathrm{p}$.

BRASIL. Ministério da Saúde. Portaria n 1886/GM, de 18 de dezembro de 1997. Aprova as normas e diretrizes do programa de agentes comunitários de saúde e do programa de saúde da família. Disponível em: $\langle$ http://189.28.128.100/dab/docs/legislacao/portaria1886_18_12_97.pdf $>$. Acesso em: 15 abr. 2011 .

BRASIL. Ministério da Saúde. Pesquisa Nacional de Saúde Bucal 2010: projeto técnico. Brasília, DF. 2009.

BRASIL. Ministério da Saúde. Portaria GM no 154, de 24 de janeiro de 2008. Cria os núcleos de apoio à saúde da família - NASF. Diário Oficial da União, Brasília, DF, 25 jan. 2008. Seção 1, p. 47-49.

BRASIL. Ministério da Saúde. Portaria MS/GM no 2.488, de 21 de outubro de 2011. Diário Oficial da União, Brasília, DF, 24 out. 2011. Seção 1, p. 48-55. 
BRASIL. Ministério da Saúde. Portaria $\mathrm{n}^{\circ}$ 1.444, de 28 de dezembro de 2000. Dispõe do estabelecimento de incentivo financeiro para a reorganização da atenção à saúde bucal prestada nos municípios por meio do Programa de Saúde da Família. Diário Oficial da União, Brasília, DF, 29 dez. 2000a. Seção 1, p. 85.

BRASIL. Ministério da Saúde. Portaria no 267, de 06 de março de 2001. Dispõe sobre as normas e diretrizes de inclusão da Saúde Bucal na Estratégia Saúde da Família. Diário Oficial da União, Brasília, DF, 7 mar. 2001. Seção 1, p. 67.

BRASIL. Ministério da Saúde. Portaria no 399, de 22 de fevereiro de 2006. Divulga o Pacto pela Saúde 2006. Brasília, DF, 2006c. Disponível em: 〈http://189.28.128.100/dab/docs/legislacao/portaria399_22_02_06.pdf $>$. Acesso em: 15 abr. 2011.

BRASIL. Ministério da Saúde. Programa de Saúde da Família: saúde dentro de casa. Brasília, DF, 1994.

BRASIL. Ministério da Saúde. Secretaria de Assistência à Saúde. Coordenação de Saúde da Comunidade. SIAB: Manual do Sistema de Informação de Atenção Básica. Brasília, DF, 1998. 98 p.

BRASIL. Ministério da Saúde. Secretaria de Atenção à Saúde. Departamento de Atenção Básica. Política nacional de atenção básica. Brasília, DF, 2006a. 60 p. (Série Pactos pela Saúde 2006, v. 4).

BRASIL. Ministério da Saúde. Secretaria de Atenção à Saúde. Diretrizes da política nacional de saúde bucal. Brasília, DF, 2004. 16 p.

BRASIL. Ministério da Saúde. Secretaria de Atenção à Saúde. Portaria no 750, de 10 de dezembro de 2006. Instituir a ficha complementar de cadastro das equipes de saúde da família; Saúde da família com saúde bucal. Brasília, DF, 2006b. Disponível em: $<$ http://dab.saude.gov.br/docs/legislacao/portaria750_10_10_06.pdf $>$. Acesso em: 10 jul. 2011.

BRASIL. Ministério da Saúde. Secretaria de Políticas de Saúde. A implantação da Unidade de Saúde da Família. Brasília, DF, 2000b. 44 p. (Cadernos de Atenção Básica, Programa de Saúde da Família, Caderno 1).

BRASIL. Ministério do Planejamento, Orçamento e Gestão. Pesquisa Nacional por Amostras de domicílios: acesso e utilização de serviços de saúde 2003. Rio de Janeiro, 2005.

CAMPOS, G. W. S. Saúde pública e saúde coletiva: campo e núcleo de saberes e práticas.

Ciênc. Saúde Coletiva, Rio de Janeiro, v. 5, n. 2, p. 219-230, 2000. 
CAMPOS, G.; CHAKOUR, M.; SANTOS, R. C. Análise crítica sobre especialidades médicas e estratégias para integrá-las ao Sistema Único de Saúde (SUS). Cad. Saúde Pública, Rio de Janeiro, v. 13, n. 1, p. 141-144, 1997.

CANESQUI, A. M. Dilemas e desafios das ciências sociais na saúde coletiva. São Paulo: Hucitec, 1995. 165 p.

CAPISTRAnO, F. D. O Programa de Saúde da Família em São Paulo. Estud. Av., São Paulo, v. 13, n. 35, 1999. Disponível em: $<$ http://www.scielo.br/scielo.php?script=sci_arttext\&pid=S0103-40141999000100008\&lng= pt\&nrm=iso>. Acesso em: 18 jul. 2007.

CAVALCANTE, M. G. S. et al. Análise de implantação das áreas estratégicas da atenção básica nas equipes de saúde da família em município de uma região metropolitana do nordeste brasileiro. Rev. Bras. Saúde Matern. Infant., Recife, v. 6, n. 4, 2006. Disponível em: <http://www.scielo.br/scielo.php?script=sci_arttext\&pid=S1519-38292006000400011\& lng= pt\&nrm=iso >. Acesso em: 18 jul. 2007.

CAVAlCANTE, R. A. et al. Perfil dos pesquisadores da área de odontologia no Conselho Nacional de Desenvolvimento Científico e Tecnológico (CNPq). Rev. Bras. Epidemiol., São Paulo, v. 11, n. 1, mar. 2008. Disponível em: $<$ http://www.scielosp.org/scielo.php?script=sci_arttext\&pid=S1415-

790X2008000100010\&lng=en\&nrm=iso>. Acesso em: 20 set. 2011.

CHAVES, M. M. Introdução. In:

Editorial Labor do Brasil, 1977. p. 5-22.

- Odontologia social. 2. ed. Rio de Janeiro:

CODO, W. O que é alienação. São Paulo: Editora Brasiliense, 1994. 96 p.

COHN, A. et al. A saúde como direito e como serviço. 3. ed. São Paulo: Cortez, 2002. 164 p.

COIMBRA, A. O outro lado do meio ambiente. Cmpinas: Millennium, 2002. 560 p.

COMISSÃO NACIONAL DE RESIDÊNCIA MÉDICA (CNRM). Resolução CNRM n. 5, de 23 de dezembro de 2003. Disponível em: http://www.fundap.sp.gov.br/rm/rm_old/Legislacoes/Res0503.htm. Acesso em: 8 out. 2011.

COMISSÃO NACIONAL DE RESIDÊNCIA MÉDICA (CNRM). Resolução no $\mathbf{1}$, de 14 de maio de 2002. Dispõe sobre os critérios básicos para credenciamento de programas de Residência Médica e dá outras providências. 2002. Disponível em: <fundap.sp.gov.br/rm/rm_old/Legislacoes/Res0102.htm>. Acesso em: 08 out. 2011. 
COMPANHIA DE DESENVOLVIMENTO ECONÔMICO DE RIBEIRÃO PRETO (CODERP). Dados econômicos. Ribeirão Preto. 2010. Disponível em <

CRACO, P. F. Ação comunicativa no cuidado à saúde da família: encontros e desencontros entre profissionais de saúde e usuários. 2005. 308 f. Tese (Doutorado) - Escola de Enfermagem de Ribeirão Preto, Universidade de São Paulo, Ribeirão Preto, 2005.

DELEUZE, G.; GUATTARI, F. Mil platôs: capitalismo e esquizofrenia, vol.1. Tradução: Guerra Neto A, Costa CP. São Paulo: Ed. 34, 2009. 91 p.

ERDMANN, A. L.; SCHLINDWEIN, B. H.; SOUSA, F. G. M. A produção do conhecimento: diálogo entre os diferentes saberes. Rev. Bras. Enferm., Brasília, DF, v. 59, n. $4,2006.2$ ago. Disponível em: <http://www.scielo.br/scielo.php?script=sci_arttext\&pid=S0034-

71672006000400017\&lng=en\&nrm=iso>. Acesso em: 20 set. 2011.

FACCIN, D.; SEBOLD, R.; CARCERERI, D. L. Processo de trabalho em saúde bucal: em busca de diferentes olhares para compreender e transformar a realidade. Ciênc. Saúde Coletiva, Rio de Janeiro, 2011. Disponível em: $<$ http://www.scielosp.org/scielo.php?script=sci_arttext\&pid=S1413-

81232010000700076\&lng=en\&nrm=iso>. Acesso em: 24 set. 2011.

FACCIN, Deniz; SEBOLD, Rafael; CARCERERI, Daniela Lemos. Processo de trabalho em saúde bucal: em busca de diferentes olhares para compreender e transformar a realidade. Ciênc. saúde coletiva, Rio de Janeiro, 2011 . Available from $<$ http://www.scielosp.org/scielo.php?script=sci_arttext\&pid=S141381232010000700076\&lng=en\&nrm=iso > access on $21 \quad$ Sept. 2011. http://dx.doi.org/10.1590/S1413-81232010000700076

FELIPE, J. S. Uma avaliação da produção teórico-científica da medicina social no Brasil. Saúde Debate, Londrina, n. 27, p. 59-66, 1989.

FERREIRA, A. B. H. Novo dicionário eletrônico Aurélio. 7. ed. Curitiba: Positivo, 2010. 1 CD-ROM.

FORTUNA, C. M. O Trabalho de equipe numa unidade de saúde: produzindo e reproduzindo-se em subjetividades. 1999. 236 f. Dissertação (Mestrado em Enfermagem de Saúde Pública) - Escola de Enfermagem de Ribeirão Preto, Universidade de São Paulo, Ribeirão Preto, 1999.

FRANCO, T. B.; MERHY, E. E. Programa de Saúde da Família (PSF): contradições de um programa destinado à mudança do modelo tecnoassistencial. In: MERHY, E. L. et al. O trabalho em saúde olhando e experienciando o SUS no cotidiano. São Paulo: Hucitec, 2003. p. 55-124. 
FREITAS, S.F.T. Cárie, Epidemiologia e Sociedade. In: BOTAZZO, C.; OLIVEIRA, M.A. Atenção básica no Sistema Único de Saúde: abordagem interdisciplinar para os serviços de saúde bucal. São Paulo: p. 203-217. Páginas e Letras. 2008.

GIL, C. R. R. Atenção primária, atenção básica e saúde da família: sinergias e singularidades do contexto brasileiro. Cad. Saúde Pública, Rio de Janeiro, v. 22, n. 6, p. 1171-1181, 2006.

GOMES, F. M.; SILVA, M. G. C. Programa Saúde da Família como estratégia de atenção primária: uma realidade em Juazeiro do Norte. Ciênc. Saúde Coletiva, Rio de Janeiro, 2011. Disponível em: <http://www.scielosp.org/scielo.php?pid=S141381232011000700021\&script=sci_arttext $>$. Acesso em: 7 out. 2011.

GOMES, R. M. O Trabalho médico e alienação: as transformações das práticas médicas e suas implicações para os processos de humanização/desumanização do trabalho em saúde. 2010. 815 f. Tese (Doutorado em Medicina Preventiva) - Faculdade de Medicina, Universidade de São Paulo, São Paulo, 2010.

GOMES, Rogério Miranda; SCHRAIBER, Lilia Blima. A dialética humanização-alienação como recurso à compreensão crítica da desumanização das práticas de saúde: alguns elementos conceituais. Interface (Botucatu), Botucatu, v. 15, n. 37, June 2011 . Available from <http://www.scielo.br/scielo.php?script=sci_arttext\&pid=S141432832011000200002\&lng=en\&nrm=iso > access on 28 Oct. 2011. http://dx.doi.org/10.1590/S1414-32832011000200002.

GONCALVES, Evelise Ribeiro; RAMOS, Flávia Regina Souza. O trabalho do cirurgiãodentista na Estratégia Saúde da Família: potenciais e limites na luta por um novo modelo de assistência. Interface (Botucatu), Botucatu, v. 14, n. 33, June 2010 . Available from <http://www.scielo.br/scielo.php?script=sci_arttext\&pid=S1414-

32832010000200006\&lng=en\&nrm=iso>. access on $17 \quad$ Sept. 2011. http://dx.doi.org/10.1590/S1414-32832010000200006.

GONCALVES, Evelise Ribeiro; RAMOS, Flávia Regina Souza. O trabalho do cirurgiãodentista na Estratégia Saúde da Família: potenciais e limites na luta por um novo modelo de assistência. Interface (Botucatu), Botucatu, v. 14, n. 33, June 2010 . Available from $<$ http://www.scielo.br/scielo.php?script=sci_arttext\&pid=S1414-

32832010000200006\&lng=en\&nrm=iso>. access on $17 \quad$ Sept. 2011. http://dx.doi.org/10.1590/S1414-32832010000200006.

GONÇALVES, R. B. M. Tecnologia e organização social das práticas de saúde. Características tecnológicas do processo de trabalho na rede estadual de Centros de Saúde de São Paulo. São Paulo: Hucitec, 1994. 278 p.

GUATTARI, F. Psicanálise e transversalidade. Aparecida: Ideias e Letras, 2004. 366 p. 
INSTITUIÇÃO. In: AURÉLIO: dicionário da língua portuguesa. 2009. Disponível em: <http://aurelioparavoce.educacional.com.br/aurelio.asp >. Acesso em: 20 out. 2009.

INSTITUTO BRASILEIRO DE GEOGRAFIA E ESTATÍSTICA (IBGE). Censo demográfico 2010. Rio de Janeiro. 2011. Disponível em < http://www.ibge.gov.br/home/estatistica/populacao/censo2010/default.shtm>. Acesso em 20 out. 2011.

JANAUDIS, M. A. Princípios da medicina de família: quatro pilares que definem sua identidade. Mundo Saúde, São Paulo, v. 34, n. 3, 2010. Disponível em: <http://www.saocamilo-sp.br/pdf/mundo_saude/77/300a310.pdf>. Acesso em: 7 out. 2011.

JAPIASSU, H. Interdisciplinaridade e patologia do saber. Rio de Janeiro: Imago, 1976.

LAPASSADE, J. G. Grupos, organizações e instituições. Tradução Henrique Augusto de Araújo Mesquita. Rio de Janeiro: Livraria Francisco Alves, 1977. 316 p.

LOURAU, R. A análise institucional. Tradução Mariano Ferreira. Petrópolis: Vozes, 1996. $294 \mathrm{p}$.

LOURAU, R. Sociólogo em tempo inteiro. Análise institucional e pedagogia. Tradução Ana Rabaça. Lisboa: Estampa, 1976. 315 p.

MAIA, M.C.G.; SAMPAIO, H.A.C.; SILVA, C.A.B. Nutrição, dieta e cárie dentária. In: DIAS, A. A. et al. Saúde Bucal Coletiva: metodologia de trabalho e práticas. São Paulo: p. 139-154. Livraria Santos. 2006.

MATOS, P. E. S.; TOMITA, N. E. A inserção da saúde bucal no Programa Saúde da Família: da universidade aos polos de capacitação. Cad. Saúde Pública, Rio de Janeiro, v. 20, n. 6, 2004. Disponível em: <http://www.scielo.br/scielo.php?script=sci_arttext\&pid=S0102311X2004000600011\&lng=pt\&nrm=iso>. Acesso em: 18 jul. 2007.

MENDES GONÇALVES. R. B. Tecnologia e organização social das práticas de saúde: características tecnológicas do processo de trabalho na rede estadual de centros de saúde de São Paulo. Hucitec, São Paulo,1994..

MENDES, E. V. A Atenção primária à saúde no SUS. Fortaleza: Escola de Saúde Pública do Ceará, 2002. 89 p.

Merhy EE. Em busca do tempo perdido: a micropolítica do trabalho vivo em saúde. In: Merhy EE, Onocko R, organizadores. Agir em saúde: um desafio para o público. São Paulo: Hucitec; 2002. p.71-112. 
MERHY, E. E. Saúde: a cartografia do trabalho vivo. São Paulo: Hucitec, 2002. 189 p.

MINAYO, M. C. S. O desafio do conhecimento: metodologia de pesquisa social (qualitativa) em saúde. 8. ed. São Paulo: Hucitec; Rio de Janeiro: Abrasco, 2004. 406 p.

NARVAI, P. C. Odontologia e saúde bucal coletiva. São Paulo: Hucitec, 1994. 113 p.

NARVAI, P. C. Saúde bucal coletiva: caminhos da odontologia sanitária à bucalidade. Rev. Saúde Pública, São Paulo, v. 40, p. 141-147, ago. 2006. Número Especial.

NARVAI, P. C. Saúde bucal: assistência ou atenção? São Paulo, 1992. Disponível em: <http://www.ccs.ufsc.br/spb/os3_narvai.pdf $>$. Acesso em: 21 set. 2011.

NUNES, E. D.. História e paradigmas da Saúde Coletiva: registro de uma experiência de ensino. Ciênc. saúde coletiva, Rio de Janeiro, v. 16, n. 4, Apr. 2011 . Available from $<$ http://www.scielosp.org/scielo.php?script=sci_arttext\&pid=S1413$81232011000400022 \& \operatorname{lng}=$ en\&nrm=iso $>$. access on 23 Nov. 2011. http://dx.doi.org/10.1590/S1413-81232011000400022.

OLIVEIRA, J. L. C.; SALIBA, N. A. Atenção odontológica no Programa de Saúde da Família de Campos dos Goytacazes. Ciênc. Saúde Coletiva, Rio de Janeiro, v. 10, 2005. Disponível em: $\quad<$ http://www.scielo.br/scielo.php?script=sci_arttext\&pid=S1413-

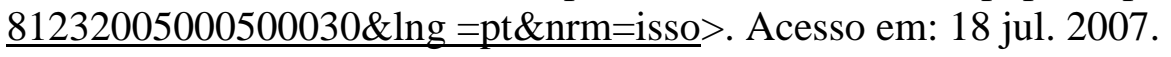

ORGANIZAÇÃO PAN-AMERICANA DE SAÚDE. A política nacional de saúde bucal no Brasil: registro de uma conquista histórica. Brasília, DF: 2006, 67 p. (Série Técnica Desenvolvimento de Sistemas e Serviços de Saúde, 11)

ORGANIZACIÓN PANAMERICANA DE LA SALUD (OPAS). Renovación de la atención primaria de salud en las Américas. Washington, D.C., OPAS/OMS, 2007. 33 p.

PASSOS, E.; KASTRUP, V.; ESCÓSSIA, L. Pistas do método da cartografia. Porto Alegre: Sulina, 2009. 207 p.

PASSOS, E.; BARROS, R. B. A construção do plano da clínica e o conceito de transdisciplinaridade. Psicol. Teoria Pesqui., Brasília, DF, v. 16, n. 1, p. 71-79, jan.-abr. 2000.

PAULON, S. M. A análise de implicação com ferramenta na pesquisa-intervenção. Psicol. Soc., Porto Alegre, v. 17, n. 3, dez. 2005. Disponível em: $<$ http://www.scielo.br/scielo.php?script=sci_arttext\&pid=S0102-71822005000300003\&lng=e

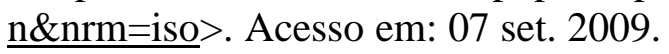


PAVIANI, J. Interdisciplinaridade: conceitos e distinções. 2. ed. Caxias do Sul: Educs, 2008. $128 \mathrm{p}$.

PEDUZZI, M. Equipe multiprofissional de saúde: conceito e tipologia. Rev. Saúde Pública, São Paulo, v. 35, n. 1, p. 103-107, 2001.

PEREIRA, I.B.; LIMA, J.C.F. (Org.). Dicionário da educação profissional em saúde. 2.ed. Rio de Janeiro: 2008. Disponível em: <http://www.epsjv.fiocruz.br/dicionario/apresentacao.html $>$. Acessado em 20 set 2011.

PICHON-RIVIÉRE, E. O processo grupal. São Paulo: Martins Fontes, 2005. 286 p.

PINTO, V.G. Saúde Bucal Coletiva. 5 ed. São Paulo: Livraria Santos Editora. 2008.

PRIMEIROS RESULTADOS DO PROJETO SBBRASIL. 2010, Brasília. SBBrasil 2010: pesquisa nacional de saúde bucal. Apresentação. 28 dez. 2010. Disponível em:< http://dab.saude.gov.br/CNSB/sbbrasil/index.html>. Acesso em: 03 nov. 2011.

REIBNITZ JUNIOR, C.; CAETANO, J. C.; PRADO, M. L. A contribuição do trabalho odontológico na resolução de problemas de saúde da população: a concepção de alunos de Odontologia. Physis, Rio de Janeiro, v. 19, n. 1, 2009. Disponível em: <http://www.scielo.br/scielo.php?script=sci_arttext\&pid=S0103-

73312009000100010\&lng=en\&nrm=iso>. Acesso em: 17 set. 2011.

RIBEIRÃo PRETO. Secretaria Municipal da Saúde. Plano Municipal de Saúde. Período 2010 - 2013. Ribeirão Preto, 2009. Disponível em < http://www.ribeiraopreto.sp.gov.br/ssaude/i16saude.php\#>. Acesso em 27 out. 2009.

ROCHA, M. L.; AGUIAR, K. F. Pesquisa-intervenção e a produção de novas análises. Psicol. Ciênc. Prof., Brasília, DF, v. 23, n. 4, p. 64-73, dez. 2003.

RODRIGUES, B. C. (Org.). René Lourau na UERJ, 1993: análise institucional e práticas de pesquisa. Rio de Janeiro, 1993. 115 p. Disponível em:< http://pt.scribd.com/doc/49274700/analise-institucional-lourau>. Acesso em: 23 nov. 2011.

SÁ, E. T. et al. O processo de trabalho na recepção de uma Unidade Básica de Saúde: ótica do trabalhador. Rev. Gaúcha Enferm., Porto Alegre, v. 30, n. 3, p. 461-467, set. 2009.

SAKATA, K.N. A inserção do agente comunitário de saúde na equipe de saúde da família.2009. 200 p. Dissertação (Mestrado em Enfermagem de Saúde Pública) - Escola de Enfermagem de Ribeirão Preto, Universidade de São Paulo, Ribeirão Preto, 2009. 
SANTOS, A. M. et al. Linhas de tensões no processo de acolhimento das equipes de saúde bucal do Programa Saúde da Família: o caso de Alagoinhas, Bahia, Brasil. Cad. Saúde Pública, Rio de Janeiro, v. 23, n. 1, 2007. Disponível em: $<$ http://www.scielo.br/scielo.php?script=sci_arttext\&pid=S0102-311X2007000100009\&lng= pt\&nrm=iso>. Acesso em: 18 jul. 2007.

SANTOS, A. M.; ASSIS, M. M. A. Da fragmentação à integralidade: construindo e (des)construindo a prática de saúde bucal no Programa de Saúde da Família (PSF) de Alagoinhas, BA. Ciênc. Saúde Coletiva, Rio de Janeiro, v. 11, n. 1, 2006. Disponível em:

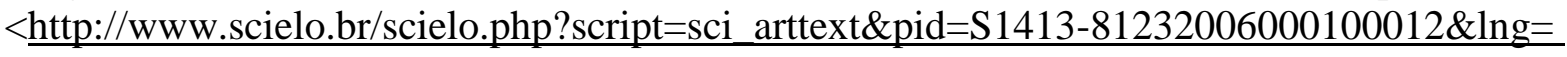
pt\&nrm=iso >. Acesso em: 18 jul. 2007.

SANTOS, L. L. Análise da percepção e registro das medidas de prevenção de doenças por profissionais da atenção primária. 2010. 154 f. Tese (Doutorado em Clínica Cirúrgica) - Faculdade de Medicina de Ribeirão Preto, Universidade de São Paulo, Ribeirão Preto, 2010. Disponível em: 〈http://www.teses.usp.br/teses/disponiveis/17/17137/tde-21122010134128/pt-br.php>. Acesso em: 17 set. 2011.

SHEIHAM, A.; MOYSÉS, S. J. O papel dos profissionais de saúde bucal na promoção de saúde. In: BUISCHI, Y. P. Promoção de saúde bucal na clínica odontológica. São Paulo: Artes Médicas, p. 387-442, 2000.

SHEIHAM, A.; WATT, R. G. The common risk factor approach: a rational basis for promoting oral health. Community Dent. Oral Epidemiol., New York, v. 28, p. 399-406, 2000 .

SHIMIZU, H. E.; REIS, L. S. As representações sociais dos trabalhadores sobre o Programa Saúde da Família. Ciênc. Saúde Coletiva, Rio de Janeiro, v. 16, n. 8, ago. 2011. Disponível em: <http://www.scielo.br/scielo.php?script=sci_arttext\&pid=S141381232011000900014\&lng=en\&nrm=iso >. Acesso em: 10 out. 2011.

SILVA, D. G. V.; TRENTINI, M. Narrativas como técnica de pesquisa em enfermagem. Rev. Latino-am. Enferm., Ribeirão Preto, v. 10, n. 3, p. 423-432, maio-jun. 2002.

SILVA, R. H. A.; SALES-PERES, A. Odontologia: um breve histórico. Odontol. Clín. Científ., Recife, v. 6, n. 1, p. 7-11, jan./mar. 2007.

SOARES, F. F. et al. Atuação da equipe de saúde bucal na estratégia saúde da família: análise dos estudos publicados no período 2001-2008. Ciênc. Saúde Coletiva, Rio de Janeiro, v. 16, n. 7, jul. 2011. Disponível em: $<$ http://www.scielo.br/scielo.php?script=sci_arttext\&pid=S1413-

81232011000800017\&lng=en\&nrm=iso>. Acesso em: 27 set. 2011. 
SOUZA, T. M. S.; RONCALLI, A.G.. Saúde bucal no Programa Saúde da Família: uma avaliação do modelo assistencial. Cad. Saúde Pública, Rio de Janeiro, v. 23, n. 11, Nov. 2007 . Available from <http://www.scielosp.org/scielo.php?script=sci_arttext\&pid=S0102311X2007001100020\&lng=en\&nrm=iso $>$ access on 24 Nov. 2011. http://dx.doi.org/10.1590/S0102-311X2007001100020.

STARFIELD, B. Atenção primária: equilíbrio entre necessidades de saúde, serviços e tecnologia. Brasília, DF: Ministério da Saúde, 2004.

TEIXEIRA, M. .C. B. A dimensão cuidadora do trabalho de equipe em saúde e sua contribuição para a odontologia. Ciênc. saúde coletiva, Rio de Janeiro, v. 11, n. 1, Mar. 2006 . Available from <http://www.scielosp.org/scielo.php?script=sci_arttext\&pid=S1413$81232006000100011 \& \operatorname{lng}=$ en\&nrm=iso $>$. access on 14 Feb. 2012.

http://dx.doi.org/10.1590/S1413-81232006000100011.

THE LJUBLJANA charter on reforming health care. Br. Med. J., London, v. 312, n. 7047, p. 1664-1665, Jun. 1996.

THIOLLENT, M. Notas para o debate sobre pesquisa-ação. In: BRANDÃO, C. R. Repensando a pesquisa participativa. 3. ed. São Paulo: Brasiliense, 2001, p. 82-103.

TRIPP, D. Pesquisa-Ação: uma introdução metodológica. Educ. Pesqui., São Paulo, v. 31, n. 3, p. 443-466, set./dez. 2005.

WATANABE, M. G. C. Mudanças curriculares no curso de Odontologia da Faculdade de Odontologia de Ribeirão Preto da Universidade de São Paulo: um olhar para a aproximação com os serviços de saúde do Sistema Único de Saúde. 2007. 222 f. Tese (LivreDocência) - Faculdade de Odontologia de Ribeirão Preto, Universidade de São Paulo, Ribeirão Preto, 2007. 


\section{APÊNDICE A - Relato da apresentação do Projeto de Pesquisa aos cinco Núcleos}

\begin{tabular}{|c|c|c|c|c|c|}
\hline & USF Prata & USF Esmeralda & USF Rubi & USF Safira & USF Onix \\
\hline $\begin{array}{l}\text { Encaminhamento do } \\
\text { CAPS }\end{array}$ & \multicolumn{5}{|c|}{$\begin{array}{l}\text { Encaminhar exemplar do projeto de pesquisa do Doutorado de Fernando Silveira, para avaliarem e apoiarem sua exequibilidade, em } 29 / 06 / 2009 \text { pelo } \\
\text { coordenador do CAP/FMRP/USP. }\end{array}$} \\
\hline Apresentação nos núcleos & 22/05/09, 8:00 & 26/05/09, 8:00 & $15 / 05 / 09,7: 45$ & 15/05/09, 9:15 & 22/05/2009, 7:30 \\
\hline Presentes & \begin{tabular}{|l|} 
Coordenador do USF, \\
médico, enfermeiro, \\
auxiliares de enfermagem, \\
agentes comunitários de \\
saúde, docentes dos Cursos \\
de Fonoaudiologia, \\
Odontologia e acadêmicos \\
de Odontologia.
\end{tabular} & $\begin{array}{l}\text { Enfermeiro, agentes } \\
\text { comunitários, acadêmicos } \\
\text { da Fisioterapia, médico. }\end{array}$ & $\begin{array}{l}\text { Coordenador do USF, } \\
\text { enfermeiro, auxiliar de } \\
\text { enfermagem, agentes } \\
\text { comunitários de saúde, } \\
\text { docentes dos cursos de } \\
\text { Nutrição, Odonto, } \\
\text { acadêmicos de Odontologia, } \\
\text { Terapia Ocuacional, } \\
\text { Nutrição, aprimoranda da } \\
\text { Psicologia, residentes de } \\
\text { medicina comunitária. }\end{array}$ & $\begin{array}{l}\text { Coordenador do USF, } \\
\text { médico, enfermeiro, } \\
\text { auxilares de enfermagem, } \\
\text { agentes comunitário de } \\
\text { saúde, dentista, residentes } \\
\text { de medicina comunitária; } \\
\text { acadêmicos de Odontologia } \\
\text { e docente do curso de } \\
\text { Odontologia. }\end{array}$ & $\begin{array}{l}\text { Enfermeiro, Médico, auxiliar } \\
\text { de enfermagem, agentes } \\
\text { comunitários de saúde, } \\
\text { dentista e docente da } \\
\text { Odontologia. }\end{array}$ \\
\hline Apresentação do Projeto & \multicolumn{5}{|c|}{$\begin{array}{l}\text { Vivência do USF H como motivador para a pesquisa, trabalho em equipe, campo e USF de competência, fundamentação na atenção primária à } \\
\text { saúde, atenção básica, Estratégia Saúde da Família, Diretrizes Nacionais de Saúde Bucal (muito superficial); objetivos da pesquisa, método de } \\
\text { pesquisa-ação, suas principais características, tais como, todos são pesquisadores, o pesquisador principal tem a função de ser um facilitador, suas } \\
\text { etapas e dinâmica de trabalho, reuniões, tempo, duração e produtos para a entrevista semiestruturada inicial, final e as prováveis durante a pesquisa. } \\
\text { A mesma apresentação foi realizada para a Patrícia, dentista do USF P II. }\end{array}$} \\
\hline Discussão & $\begin{array}{l}\text { O projeto foi tido como } \\
\text { interessante, mas que havia } \\
\text { dificuldade de horários, uma } \\
\text { vez que já há outro projeto } \\
\text { em andamento. Seria } \\
\text { necessário compatibilizar o } \\
\text { horário com outros projetos. } \\
\text { Houve uma fala sobre a } \\
\text { dificuldade de encontrar } \\
\text { espaços para discutir até } \\
\text { entre a equipe as questões } \\
\text { da enfermagem, a qual se } \\
\text { faz necessária. Ressaltei } \\
\text { que embora fosse uma } \\
\text { pesquisa, ela trará }\end{array}$ & $\begin{array}{l}\text { Foi solicitado } \\
\text { esclarecimentos sobre as } \\
\text { etapas da pesquisa, sendo } \\
\text { informados os ciclos, a } \\
\text { entrevista semiestruturada } \\
\text { inicial e final e talvez uma } \\
\text { intermediária, dei exemplos } \\
\text { do que poderia ser } \\
\text { trabalhado; produtos para a } \\
\text { equipe, na forma fôlder, } \\
\text { manual, etc. Uma das } \\
\text { agentes perguntou-me se } \\
\text { iria discutir sobre a forma de } \\
\text { atendimento e foi explicado } \\
\text { que a proposta da pesquisa }\end{array}$ & $\begin{array}{l}\text { As manifestações foram } \\
\text { positivas quanto à } \\
\text { participação no projeto: pela } \\
\text { inserção do pesquisador na } \\
\text { equipe, pelo fato de a } \\
\text { pesquisa proporcionar } \\
\text { retorno para o serviço, pela } \\
\text { necessidade de interagir os } \\
\text { conhecimentos de Saúde } \\
\text { Bucal com as outras áreas } \\
\text { da saúde. } \\
\text { Docente da odonto } \\
\text { argumentou o crescimento e } \\
\text { fortalecimento da equipe e } \\
\text { produtos gerados pela }\end{array}$ & $\begin{array}{l}\text { Imediatamente falou-se da } \\
\text { importância do projeto e da } \\
\text { vontade de participar da } \\
\text { investigação e das } \\
\text { dificuldade de conseguir um } \\
\text { horário e destinar um } \\
\text { período para esta atividade } \\
\text { em vista das demandas do } \\
\text { serviço. Houve sugestão } \\
\text { para realizar às quintas- } \\
\text { feiras, embora os residentes } \\
\text { não possam participar. } \\
\text { Perguntou-se se a } \\
\text { participação dos residentes } \\
\text { era indispensável. O }\end{array}$ & $\begin{array}{l}\text { Todos acharam interessante } \\
\text { a pesquisa, sendo favoráveis } \\
\text { dentista, médico, enfermeira } \\
\text { e o docente da Odontologia. } \\
\text { É possível encontrar espaço } \\
\text { para esta atividade no USF. }\end{array}$ \\
\hline
\end{tabular}




\begin{tabular}{|c|c|c|c|c|c|}
\hline & \begin{tabular}{|l|} 
resultados imediatos para a \\
equipe. Enfim, combinou-se \\
que para realizar o trabalho \\
nesta unidade, será \\
necessário organizar um \\
horário entre a equipe e o \\
pesquisador.
\end{tabular} & $\begin{array}{l}\text { é discutir aquilo que é de } \\
\text { interesse para a equipe, } \\
\text { iniciando pela entrevista } \\
\text { com cada membro da } \\
\text { equipe. Na primeira } \\
\text { reunião, seria apresentado } \\
\text { em forma de relatório, com } \\
\text { questões que a equipe } \\
\text { apontou para trabalharmos e } \\
\text { que o grupo escolherá o } \\
\text { tema. Discutimos sobre as } \\
\text { disponibilidades de horários } \\
\text { para o trabalho da pesquisa, } \\
\text { e a equipe disponibilizou } \\
\text { horários nas reuniões de } \\
\text { sexta, chegar meia hora } \\
\text { mais cedo. Ficou } \\
\text { combinado que o horário } \\
\text { seria discutido com a } \\
\text { equipe, após indicação do } \\
\text { USF para a investigação.. } \\
\text { No final a enfermeira } \\
\text { Andréia perguntou se a } \\
\text { equipe ali presente } \\
\text { concordava com a } \\
\text { realização do projeto, e } \\
\text { todos concordaram, alguns } \\
\text { expressivamente, outros } \\
\text { com silêncio. } \\
\text { Com a Patrícia não houve } \\
\text { perguntas ou } \\
\text { questionamentos,e houve } \\
\text { manifestação de disposição } \\
\text { para colaborar. Fiquei com } \\
\text { a impressão de que ela não } \\
\text { compreendeu o projeto de } \\
\text { pesquisa. }\end{array}$ & pesquisa. & \begin{tabular}{|l|} 
pesquisador informou que a \\
participação dos residentes \\
era importante, mas se a \\
equipe dispusesse apenas \\
daquele horário a pesquisa \\
poderia ser realizada da \\
mesma forma. Foi solicitado \\
à equipe que esta \\
informação constasse do \\
parecer do Projeto e \\
informou-se sobre a \\
realização do projeto em \\
apenas uma unidade. Estas \\
informações são importantes \\
para a escolha da equipe. \\
Wilson manifestou interesse \\
na realização do projeto, \\
indicando o USF S IV como \\
local privilegiado para sua \\
execçcão em virtude da \\
reorganização do serviço na \\
unidade.
\end{tabular} & \\
\hline $\begin{array}{l}\text { Situação dos pareceres no } \\
\text { UBDS CITRINO em } \\
\text { 29/05/2009. }\end{array}$ & $\begin{array}{l}\text { Recebido pelo UBDS } \\
\text { CITRINO. }\end{array}$ & Nada consta & $\begin{array}{l}\text { Recebido pelo UBDS } \\
\text { CITRINO. }\end{array}$ & Nada consta & $\begin{array}{l}\text { Recebido pelo UBDS } \\
\text { CITRINO. }\end{array}$ \\
\hline Parecer do USF no Projeto & $\begin{array}{l}\text { 22/05/2009. O projeto foi } \\
\text { apresentado para a equipe }\end{array}$ & $\begin{array}{l}\text { Sem data. Equipe encontra- } \\
\text { se de acordo. Projeto já }\end{array}$ & $\begin{array}{l}\text { 15/05/2009. Em reunião } \\
\text { realizada dia } 15 \text { de maio de }\end{array}$ & $\begin{array}{l}\text { Sem data. Solicito que o } \\
\text { pesquisador agende contato }\end{array}$ & $\begin{array}{l}\text { 11/05/2009. Solicitamos } \\
\text { que o pesquisador }\end{array}$ \\
\hline
\end{tabular}




\begin{tabular}{|c|c|c|c|c|c|}
\hline & $\begin{array}{l}\text { que reconhece a } \\
\text { importância e a pertinência } \\
\text { do tema. Temos interesse } \\
\text { na realização do projeto, no } \\
\text { entanto, para a viabilização } \\
\text { do projeto necessitamos de } \\
\text { uma maior discussão, pois } \\
\text { temos um outro projeto de } \\
\text { pesquisa de longa duração } \\
\text { (até dez 2009) que ocorre às } \\
\text { sextas-feiras, ocupando } \\
90 \% \text { da reunião } \\
\text { administrativa. Seria } \\
\text { possível a realização em um } \\
\text { outro período da semana. } \\
\text { Luciane Santos }\end{array}$ & $\begin{array}{l}\text { apresentado na unidade. } \\
\text { Anderson Soares }\end{array}$ & $\begin{array}{l}\text { 2009, após apresentação do } \\
\text { projeto do pesquisador } \\
\text { Fernando Silveira à equipe, } \\
\text { foram salientados os } \\
\text { seguintes pontos: } \\
\text { - Levando em consideração } \\
\text { que o pesquisador já possui } \\
\text { um tempo considerável de } \\
\text { inserção na equipe e por ser } \\
\text { a metodologia eleita a } \\
\text { pesquisa-ação, o mais } \\
\text { recomenáavel é de que o } \\
\text { pesquisador realize o projeto } \\
\text { nesta unidade; } \\
\text { - a equipe foi bastante } \\
\text { receptiva aos objetivos da } \\
\text { pesquisa e à questão } \\
\text { investigada pelo } \\
\text { pesquisador. Enfermeiro do } \\
\text { USF H }\end{array}$ & $\begin{array}{l}\text { com a equipe do NSF } 4 \text { para } \\
\text { discutir o projeto e sua } \\
\text { execução. André Marinheiro } \\
07 / 05 / 2009 \text {. Comunico que } \\
\text { fiz contato telefônico com } \\
\text { Dr. Fernando Silveira para } \\
\text { agendar apresentação para } \\
\text { equipe. Devolvo o mesmo } \\
\text { para anotações após a } \\
\text { apresentação.Cristina } \\
\text { Sem data. Apresentação } \\
\text { feira em 15/05/2009. De } \\
\text { acordo. André Marinheiro }\end{array}$ & $\begin{array}{l}\text { compareça à uma reunião } \\
\text { da equipe para esclarecer } \\
\text { questões sobre o projeto. } \\
\text { Márcia Domingos. } \\
21 / 05 / 2009 \text {. Feito contato } \\
\text { telefônico para que o } \\
\text { pesquisador entre em } \\
\text { contato com o NSF } 5 . \\
\text { Cristina. } \\
\text { 25/05/2009. A equipe está } \\
\text { de acordo com a realização } \\
\text { do estudo nesta unidade } \\
\text { com a condição de } \\
\text { combinarmos os horários. } \\
\text { Márcia Domingos }\end{array}$ \\
\hline $\begin{array}{l}\text { Considerações sobre a } \\
\text { apresentação }\end{array}$ & $\begin{array}{l}\text { Boa receptividade. } \\
\text { Dificuldade com horários. O } \\
\text { pesquisador está inserido } \\
\text { nesta equipe, em virtude do } \\
\text { trabalho com os alunos. A } \\
\text { enfermeira possui } \\
\text { temperamento difícil, } \\
\text { embora seja tecnicamente } \\
\text { muito competente. Neste } \\
\text { momento não há dentista } \\
\text { neste USF. }\end{array}$ & $\begin{array}{l}\text { O último USF a ser realizado } \\
\text { a apresentação, após dois } \\
\text { contatos em intervalos de } \\
\text { uma semana, estou } \\
\text { aguardando resposta, 24/05. } \\
\text { A dentista não estava } \\
\text { presente, devido suas } \\
\text { atividades no UBDS } \\
\text { CITRINO. No dia 28/05 foi } \\
\text { apresentado o projeto ao } \\
\text { dentista, tendo manifestação } \\
\text { favorável no final. }\end{array}$ & $\begin{array}{l}\text { Ótima receptividade, O } \\
\text { pesquisador está inserido } \\
\text { neste USF, acompanhando } \\
\text { os atendimentos dos alunos } \\
\text { no USF. Não tem dentista } \\
\text { até este momento. O } \\
\text { docente da FORP apoia a } \\
\text { pesquisa. }\end{array}$ & $\begin{array}{l}\text { Resistência por parte da } \\
\text { enfermeira e médico. Apoio } \\
\text { do docente da Forp e do } \\
\text { restante da equipe como } \\
\text { forma de colaborar na } \\
\text { reestruturação do serviço. } \\
\text { Há dentista na unidade. }\end{array}$ & $\begin{array}{l}\text { Boa receptividade. Há } \\
\text { dentista na equipe. Docente } \\
\text { da Forp apoia a pesquisa. }\end{array}$ \\
\hline
\end{tabular}




\section{Apêndice B - TERMO DE CONSENTIMENTO LIVRE E ESCLARECIDO.}

$\mathrm{Eu}$ , abaixo assinado, aluno do Curso de Doutorado do Programa de Pós Graduação em Enfermagem em Saúde Pública da Escola de Enfermagem de Ribeirão Preto, USP, estou realizando um trabalho de pesquisa sobre "A Prática da Saúde Bucal nas Equipes de Saúde da Família", sob a orientação da Prof ${ }^{a}$ Dra. Silvana Martins Mishima e da $\operatorname{Prof}^{a} \operatorname{Dr}^{a}$ Marlívia G. C. Watanabe. Este trabalho tem o objetivo de estudar a aquisição, a construção e o uso de práticas de saúde bucal, coletivas e individuais, pelos profissionais da equipe de saúde da família. Assim, solicitamos a colaboração dos profissionais da unidade (médicos, enfermeiros, cirurgiões dentistas, técnicos e auxiliares de enfermagem, agentes comunitários e outros profissionais de saúde) para participar das atividades da pesquisa: individuais (as entrevistas semi estruturadas) e coletivas (reuniões e grupos de estudo). Haverá registro escrito e gravação de todas atividades e posterior análise. Estas informações serão utilizadas exclusivamente para a pesquisa, mantendo-se o caráter confidencial das informações obtidas e o sigilo quanto aos nomes das pessoas participantes. Os resultados obtidos deverão ser divulgados em revistas e eventos científicos assim que se obtenham resultados consistentes, e após a aprovação do CEP. Os membros terão liberdade total de se recusarem a participar da pesquisa ou retirar seu consentimento, em qualquer momento, sem penalizações ou prejuízos pessoais. E por fim, comprometemo-nos em devolver os resultados para os profissionais, após a conclusão da pesquisa. Os contatos poderão ser realizados no Departamento de Enfermagem MaternoInfantil e Saúde Pública da Escola de Enfermagem de Ribeirão Preto da Universidade de São Paulo, localizada na Avenida Bandeirantes $\mathrm{n}^{\circ} 3.900$, Campus Universitário Ribeirão Preto CEP: 14040-902 e telefones (016) 3602-3949, 3602-3951, 3602-3969.

Ribeirão Preto, de de 2009.

CD Fernando Silveira. G.C.Watanabe. (doutorando EERP/USP)

\author{
$\operatorname{Prof}^{\mathrm{a}}$ Dr $^{\mathrm{a}}$ Silvana M. Mishima. \\ (orientador da pesquisa)
}

Prof $^{\mathrm{a}}$ Dr $^{\mathrm{a}}$ Marlívia

(co orientador da pesquisa)

\section{TERMO DE CONSENTIMENTO}

$\mathrm{Eu}$, , RG:

abaixo assinado, declaro ter recebido informações sobre o projeto de pesquisa "A Prática da Saúde Bucal nas Equipes de Saúde da Família", estar informado que não serei identificado, que será mantido o caráter confidencial das informações obtidas, que ocorrerá publicação dos resultados encontrados e que não terei gastos com a minha participação. Desta forma, consinto em participar desta pesquisa e de suas atividades, quer sejam entrevistas, reuniões ou grupos de estudo. Também estou ciente que haverá registro das atividades por meio da escrita e gravações de áudio e, que posteriormente serão analisadas.

Ribeirão Preto, de de 2009. 
APÊNDICE C - ORIENTAÇÕES PARA RECEPÇÃO DOS USUÁRIOS DA USF RUBI.

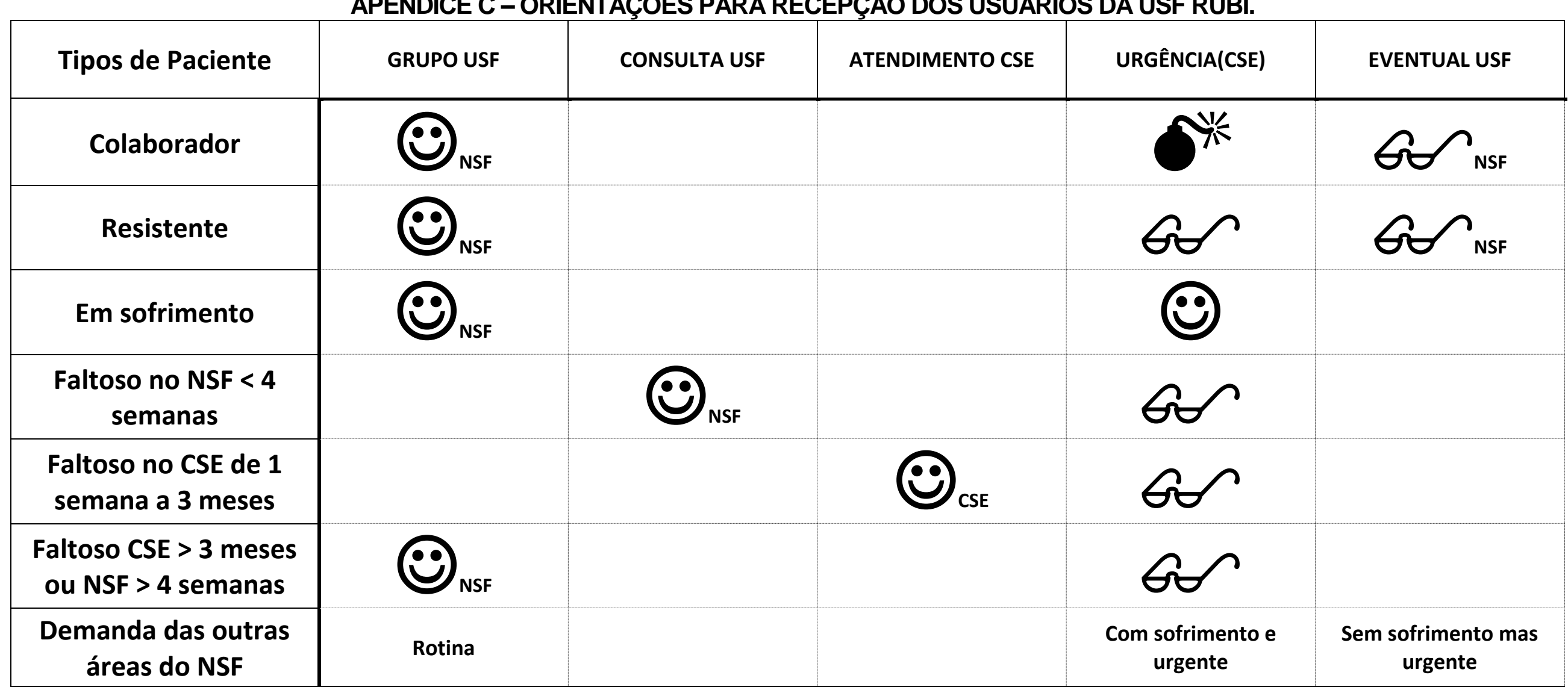

Legenda: :)CSE : primeira opção e agendamento na unidade da porta de entrada pelo CSE; $\boldsymbol{\sigma}^{*}$ : também é importante verificar a necessidade de atendimento imediato; or:também verificar se há necessidade de atendimento imediato.

Orientações:

1 - Atendimento de Urgência: de $2^{\mathrm{a}}$ a $6^{\mathrm{a}}$ feiras as 17:00 horas; 7:00 horas e 12:00 horas, preferencialmente. Casos de sofrimento (dor, estética, ...)

2 - No agendamento anotar no Cartão de Retorno usando a linha das duas colunas com data, horário, unidade de serviço (CSE ou USF H) e nome do profis.

3 - Os agendamentos de usuários em seguimento no CSE serão feitos no próprio CSE: $2^{\underline{a}}$ feira das 7:30 as 12:00 e $5^{\underline{a}}$ e $6^{\underline{a}}$ feiras das 13:00 as 17:00 horas. 
APÊNDICE D - IMPRESSOS PARA AGENDA DA SAÚDE BUCAL - 2011

Famílias em seguimento pela Saúde Bucal da USF H

Grupo do dia:

Coordenador:

Motivadores/Observadores:

Participantes inscritos para seguimento:

\begin{tabular}{|c|c|c|c|c|c|c|c|c|c|}
\hline \multicolumn{2}{|c|}{ IDENTIFICAÇÃO } & \multicolumn{5}{|c|}{ EVOLUÇÃO } & \multicolumn{3}{|c|}{ RESOLUCÃO } \\
\hline $2-$ & 1 & $(1)$ & 1 & 1 & 1 & 1 & 1 & 1 & \\
\hline $3-$ & I & $(1)$ & 1 & 1 & I & 1 & I & 1 & \\
\hline $5-$ & 1 & $(1)$ & 1 & 1 & 1 & 1 & 1 & 1 & \\
\hline $6-$ & 1 & $(1)$ & 1 & I & 1 & 1 & 1 & 1 & \\
\hline $7-$ & 1 & $(1)$ & 1 & 1 & 1 & 1 & 1 & 1 & \\
\hline $8-$ & 1 & $(1)$ & 1 & 1 & 1 & 1 & 1 & 1 & \\
\hline $11-$ & 1 & $(1)$ & 1 & 1 & 1 & 1 & 1 & 1 & \\
\hline $12-$ & I & $(1)$ & I & 1 & I & 1 & 1 & 1 & \\
\hline
\end{tabular}

Participantes suplentes inscritos para seguimento:

\begin{tabular}{|c|c|c|c|c|c|c|}
\hline \multicolumn{2}{|c|}{ IDENTIFICAÇÃO } & \multicolumn{3}{|c|}{ EVOLUÇÃO } & \multicolumn{2}{|c|}{ RESOLUÇÃO } \\
\hline Nome /hygea/telefone & Família/M A & Grupo & C S Bucal & Atend CSE & Novo Ciclo & Encaminhamento \\
\hline $2-$ & 1 & $(1)$ & 1 & 1 & 1 & \\
\hline $3-$ & 1 & $(1)$ & 1 & 1 & 1 & \\
\hline $5-$ & 1 & $(1)$ & 1 & 1 & 1 & \\
\hline
\end{tabular}




\section{Agenda de Saúde Bucal da USF H - 2010}

\begin{tabular}{|c|c|c|c|c|}
\hline \multicolumn{5}{|c|}{ Quarta Feira - ___ ${ }^{\prime}$} \\
\hline Horário & Nome & Telefone & Família/ M. Área & Faltou/Compareceu \\
\hline $14: 00$ & & & 1 & () \\
\hline $14: 30$ & & & l & ( ) \\
\hline 15:00 & & & l & ( ) \\
\hline $15: 30$ & & & l & ( ) \\
\hline $16: 00$ & & & 1 & ( ) \\
\hline
\end{tabular}

\begin{tabular}{|c|c|c|c|c|}
\hline \multicolumn{5}{|c|}{ Quinta Feira - __ $/$} \\
\hline Horário & Nome & Telefone & Família/ M. Área & Faltou/Compareceu \\
\hline 08:30-CS 1 & & & 1 & ( ) \\
\hline $08: 30-\operatorname{CS} 2$ & & & 1 & () \\
\hline 09:00-CS 1 & & & 1 & ( ) \\
\hline 09:00-CS 2 & & & 1 & ( ) \\
\hline 09:30-CS 1 & & & 1 & ( ) \\
\hline 09:30-CS 2 & & & 1 & ( ) \\
\hline $10: 00$ & & & 1 & ( ) \\
\hline $10: 30$ & & & 1 & ( ) \\
\hline $11: 00$ & & & 1 & $($ ) \\
\hline
\end{tabular}




\section{ANEXO A - PARECER DO COMITÊ DE ÉTICA EM PESQUISA DO CSE-FMRP-USP}

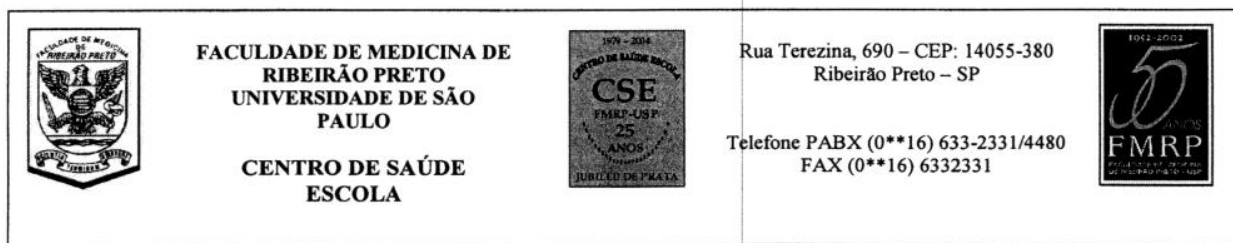

COMITÉ DE ÉTICA EM PESQUISA DO CENTRO DE SAÚDE ESCOLA DA FACULDADE DE MEDICINA DE RIBEIRÃO PRETO DA UNIVERSIDADE DE SÃO PAULO-CEPICSE-FMRP-USP.

Ribeirão Preto, 15 de julho de 2009.

Of. $N^{\circ} .134 / 09 /$ COORD.CEP/CSE-FMRP- USP.

Senhora Professora,

Temos a grata satisfação de comunicar que o Coordenador do Comitê de Ética em Pesquisa do Centro de Saúde Escola da Faculdade de Medicina de Ribeirão Preto da Universidade de São Paulo, em reunião, realizada em 14 de julho de 2009, analisou e apreciou o parecer, referente ao projeto de pesquisa: "A prática da Saúde Bucal nas Equipes de Saúde da Família", protocolo n ${ }^{\circ} .323 / C E P-C S E-F M R P-U S P$, sob a orientação de V.S ${ }^{\mathrm{a}}$. com a coorientação da Prof ${ }^{a}$.Dra. Marlívia Carvalho G. Watanabe e como pesquisador Fernando da Silveira (aluno do Programa de Pós-Graduação de Enfermagem em Saúde Pública da Escola de Enfermagem de Ribeirão Preto-USP), foi aprovado ad-referendum.

Em atendimento à Resolução 196/96, deverá ser encaminhado a este CEP, o relatório final da pesquisa e a publicação de seus resultados.

No ensejo, renovamos os votos de estima e consideração, despedimo-nos.

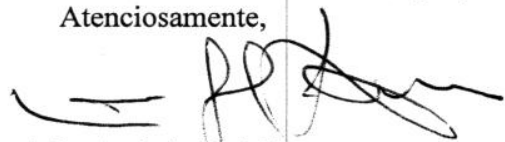

Prof. Dr. Laércio Jolel Franco

Coordenador do CEP/CSE-FMRP-USP

Ilma. Sra.

Prof $^{\mathrm{a}}$. Dr ${ }^{\mathrm{a}}$. Silvana Martins Mishima

Departamento de Enfermagem, Materno Infantil e Saúde Pública-

Escola de Enfermagem de Ribeirão Preto-USP. 


\section{ANEXO B- AUTORIZAÇÃO DO CAP-FMRP-USP PARA A REALIZAÇÃO DA PESQUISA}

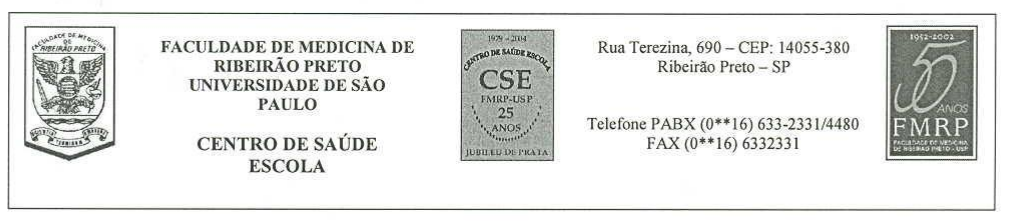

Ribeirão Preto, 02 de junho de 2009

\section{DECLARAÇÃO}

Declaramos que o pesquisador DR. FERNANDO

SILVEIRA, apresentou o Projeto de Pesquisa Intitulado: "A PRÁTICA DA SAÚDE BUCAL NAS EQUIPES DE SAÚDE DA FAMÍLIA", para apreciação, sendo aprovado nos Núcleos de Saúde da Família-I, II, III, IV e V do Centro de Saúde Escola da Faculdade de Medicina de Ribeirão PretoUSP. A Direção Acadêmica de Ensino e Pesquisa aguarda as questões éticas a serem apreciadas pelo Comitê de Ética em Pesquisa para que se inicie o desenvolvimento do mesmo.

$$
\begin{aligned}
& \text { Prof. Dr. Gutemberg de Melo Rocha } \\
& \text { Presidente do Centro de Atenção Primária da } \\
& \text { FMRP-USP }
\end{aligned}
$$

Ilma. Sra.

Prof". Dra. Silvana Martins Mishima (Orientadora)

Departamento de Enfermagem Materno Infantil e

Saúde Pública da Escola de Enfermagem de

Ribeirão Preto-USP 